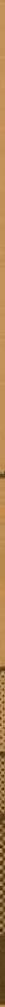

\title{
MASTER
}

\section{Environmental Research on a Modified In Situ Oil Shale Task Process:}

A Progress Report

May 1980

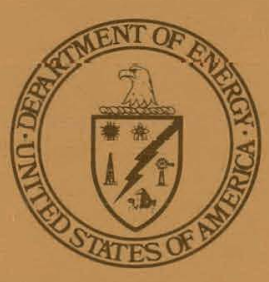

U.S. Department of Energy

Assistant Secretary for Environment \& Safety Division of Ecological Research 


\section{DISCLAIMER}

This report was prepared as an account of work sponsored by an agency of the United States Government. Neither the United States Government nor any agency Thereof, nor any of their employees, makes any warranty, express or implied, or assumes any legal liability or responsibility for the accuracy, completeness, or usefulness of any information, apparatus, product, or process disclosed, or represents that its use would not infringe privately owned rights. Reference herein to any specific commercial product, process, or service by trade name, trademark, manufacturer, or otherwise does not necessarily constitute or imply its endorsement, recommendation, or favoring by the United States Government or any agency thereof. The views and opinions of authors expressed herein do not necessarily state or reflect those of the United States Government or any agency thereof. 


\section{DISCLAIMER}

Portions of this document may be illegible in electronic image products. Images are produced from the best available original document. 


\section{Environmental Research on a Modified In Situ Oil Shale Task Process:}

\section{A Progress Report}

\section{May 1980}
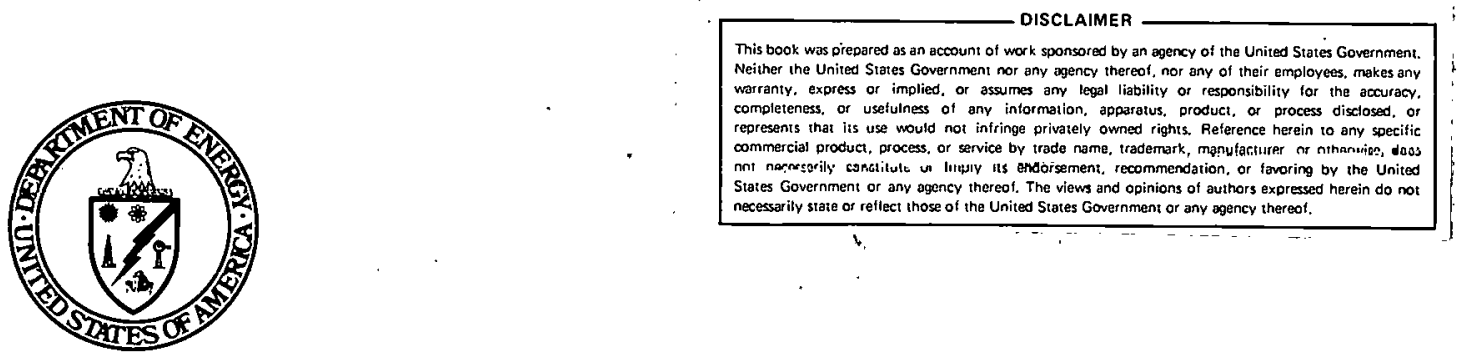

The Oil Shale Task Force

\section{U.S. Department of Energy}

Assistant Secretary for Environment \& Safety

Division of Ecological Research

Washington, D.C. 20545 
Avallable from:

National Technical Information Service (NTIS)

U.S. Department of Comperce

5285 Port Royal Road

Springfield, Virginia 22161

Price:

G. $\infty 0$

$\begin{array}{ll}\text { Printed Copy: } & \$ 6.50 \\ \text { Microfiche: } & \$ 3.00\end{array}$ 


\section{PREFACE}

This environmental report by the Department of Energy 0il Shale Task Force is the first of a series which will describe the progress of our environmental research activities. The Task Force was created in May 1978 in order to coordinate the environmental research on oil shale that is being funded by the Department of Energy. The Task Force also serves as a focal point for interaction with state and local government, industry, public interest groups, the research community, federal agencies such as the Environmental Protection Agency and the Department of Interior, and other groups and individuals concerned with oil shale.

One of the first efforts of the Task Force was to plan and implement a research porgram focused on the modified in situ (MIS) research project being conducted by Occidental Oil Shale, Inc. (Oxy) at its Logan Wash, Colorado site with partial funding from the Department of Energy. This environmental research program was implemented. in March 1979. Numerous samples have been collected and distributed for chemical analysis and biological testing. This effort constitutes the first comprehensive environmental research program focused on MIS. This report is the first progress report on those activities. The results should be considered preliminary in nature and need to be confirmed by additional analysis and testing. Nonetheless, there are implications for future research requirements.

More recently DOE has established a Program Management Team for the Oil Shale Program. The Management Team is organized into four functional units; termed activities, of which environment is one. The Task Force will interface closely with the Management Team and continue to serve as a focal point for coordinating environmental activities of the Management Team. An advisory group and the other interactive mechanisms which were established by the Task Force, will continue to operate and serve the Management Team as well.

DOE's environmental activities will emphasize the development of acceptable solutions to the environmental problems as they are identified. Research will be directed after a series of tasks to achieve a set of key "deliverables" described in a management plan (see Oil Shale RD\&D Program Management, Department of Energy, July 1979, Draft). The key "deliverables" aimed at removing the major environmental constraints include:

- Develop an environmentally acceptable retort abandonment strategy.

- Establish guidelines to ensure worker health and safety.

- Develop solid waste management systems.

- Develop waste water treatment systems.

- Develop an emission control strategy.

- Design plans for site rehabilitation, mitigation of socioeconomic impacts, and cnvironmental compliance. 
- Develop a plan for protection of general ecological resources.

The research strategy to be followed in implementation of the plan is shown on page $i v$. The research described in this report contributes to the data base development. Future reports will contribute to risk analysis and controls and mitigation development.

Joseph Blair

Gerald Goldstein

Charles Grua

David Smith

Ralph Franklin, R\&D Coordinator 


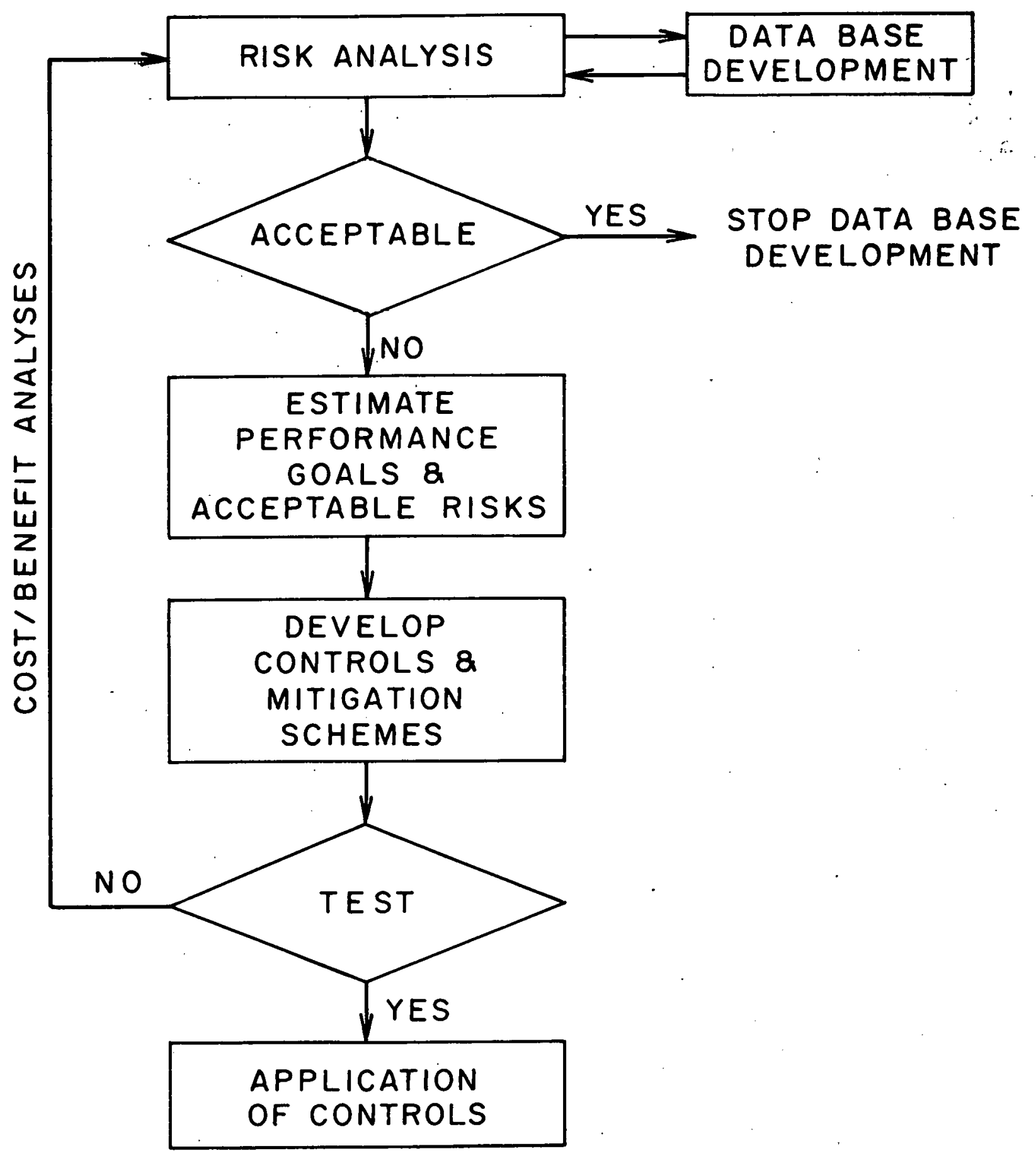

Research Strategy 
THIS PAGE

\section{WAS INTENTIONALLY LEFT BLANK}




\section{EXECUTIVE SUMMARY}

This report summarizes the progress of the U.S. Department of Energy's Oil Shale Task Force in its research program at the Occidental Oil Shale,."Inc. facility at Logan Wash, Colorado. More specifically, the Task Force obtained samples from Retort $3 E$ and Retort 6 and submitted these samples to a variety of analyses. The samples collected included:

- Liquid:

--Crude 0il (Retort 6)

--Light 0il (Retort 6)

--Product Water (Retort 6)

--Boiler Blowdown (Retort 6)

--Makeup Water (Retort 6)

--Mine Sump Water

--Groundwater

- -Water from Retorts 1-5

- Gaseous :

--Retort Gas (Retort 6)

--Mine Air

- Solid :

--Mine Dust

--Spent Sha1e Core (Retort 3E)

The loçations of the sampling points and methods used for collection and storage are discussed in Chapter 2 (Characterization). These samples were then distributed to the various laboratories and universities participating in the Task Force.

For convenience in organizing the data, it is useful to group the work into three categories: Characterization, Leaching, and Health Effects. While many samples still have not been analyzed and much of the data remains to be interpreted, there are some preliminary conclusions the Task Force feels will be helpful in defining future needs and establishing priorites.

It is important to note that drilling agents other than water were used in the recovery of the core from Retort 3E. These agents have been analyzed (see Table 12 in Chapter 2) for several constituents of interest. As a result some of the analyses of this core sample and leachates must be considered tentative. 


\section{CHARACTERIZATION STUDIES}

There are several objectives of this task. They include collection and distribution of samples, determination of physical and chemical characters as a function of time and other parameters, and the improvement of analytical methods. Some of the principal conclusions are:

- Liquid Samples:

--Those samples of Oxy oil that have been analyzed have lower concentrations of arsenic and selenium and higher concentrations of vanadium, cobalt, nickel, and zinc than other shale oils that have been analyzed.

--In general, the shale oils that have been measured (both surface and MIS) are higher in arsenic, selenium, cobalt, and nitrogen and lower in vanadium and nickel compared to crude petroleums.

--Retort 6 product waters are compositionally different from product waters produced by above-ground processes.

--Although the concentrations of many elements and chemical species are lower in effluents from Retort 6 compared to above-ground retorts, higher water and gas production rates per barrel of oil are often involved with MIS processes and these may lead to higher total emissions per barrel of oil for some substances by the MIS process.

- Gaseous Samples:

--Mercury has been detected in all gas samples which have been analyzed to date.

--Very little arsenic in any form is present in these samples.

- Solid Samples:

--The core samples from Retort 3E show considerably greater compositional variation than found in shale samples from above-ground and simulated in situ retorts.

--Boron, flouride, arsenic, sulfur, and molybdenum generally increase with depth. Other elements fluctuate more or less randomly with depth.

--A11 core samples measured showed residual mercury concentrations as opposed to spent shales obtained from simulated in situ retorts.

--0xy spent shales are generally higher in boron and calcium and lower in sodium and molybdenum than other spent shales studied to date.

No time-sequenced studies have been completed for Retort 6 . In general, the Task Force feels that in order to draw firm conclusions about emissions from an MIS process, it will be necessary to continue studies of a steadily burning commercial size retort. 


\section{LEACHING STUDIES}

Leaching studies were performed on eighteen small samples of Retort $3 \mathrm{E}$ retorted shale provided by Occidental Oil Shale, Inc. These studies were performed in order to investigate the mechanism and consequences of release of elements from Oxy MIS retorted shale. In addition, some of the studies were designed to determine whether high MIS retorting temperatures would produce refractory minerals with a resulting decrease in aqueous leaching of inorganic and organic residuals.

Conclusions from the leaching studies are complïcated by a lack of pre-burn and mineralogic information, a lack of mineralogic information on several core samples, and the possibility that the leached concentrations reflect processes which occurred during and after the burn rather than characteristic of the retorted shale. Conclusions are further complicated by the fact that these Retort $3 \mathrm{E}$ core samples were obtained using pipe dope, foam, and surfactant to facilitate sample retrieval. The use of these materials complicates the interpretation of leaching data, and further research is necessary to clarify, if possible, the impact of the drilling activities. (Recently additional cores, R3E2 and R3E3, were taken without the use of drilling fluids other than water.) Nevertheless, these initial leaching data contain significant information on MIS retorted shale.

Primary conclusions from the initial leaching studies of Oxy Retort 3E retorted shale are:

- Although the Retort 3E shale was exposed to high retorting temperatures, a water soluble fraction exists and is rapidly leached from the retorted shale under laboratory conditions.

- Leachate concentrations of aluminum, arsenic, boron, fluoride, molybdenum, selenium, and vanadium are sufficiently high to warrant further investigation to determine whether they are of environmental concern.

- Retort 3E can be divided into a small number of zones or divisions which give similar leachates. This implies that retorting conditions (e.g., temperature) and/or the character of the initial raw shale may play a significant role in determining the character of the leachate: If so, the environmental impact could be lessened by using appropriate retorting conditions.

A detailed list of conclusions and a discussion of the conclusions can be found in Chapter 3 (Leaching). 


\section{HEALTH STUDIES}

Because many health studies (e.g., long-term animal exposures) take many months and in some cases years, the information now available comes from the in vitro tests and in particular the Ames Assay for mutagenic activity. However, results are now available from inhalation studies of raw shale dust obtained from the Anvil Points retorting facility. While minor differences in oil shale lithology exist throughout the Piceance Basin, the raw shale dust from Anvil Points serves as a basis for study until physical and chemical analyses can determine whether it is indeed representative of other potential development sites. 'The results of these analyses will be reported at a later date.

The health studies to date show that:

- The Oxy crude shale oil from Retort 6 at Logan Wash and several associated by-products (product water, boiler blowdown, etc.) were found to possess either a very low order mutagenic activity or no activity at all.

- Early results from the inhalation studies using raw oil shale from another location have failed to demonstrate a carcinogenic effect following sixteen months of exposure at dust concentrations well above the anticipated industrial exposures.

- Industrial hygiene sampling of the mine atmosphere at Logan Wash revealed no significant dust levels above standards for nuisance dusts having relatively high silica content.

- Two different types of particles were detected in the mine atmosphere. One type, a solid compact particle, was found to possess a higher silica content than the other type, a porous particle, which possesses a higher calcium content than the first type.

However, it must be noted that additional results are required in order to determine whether these preliminary results are truly representative of the process. 
Executive Summary

Characterization Studies

Leaching Studies

Health Studies

1. Introduction

Background

The MIS Process

Research Areas

Workshop

2. Characterization 11

Introduction 11

Sample Collection and Preservation. $\quad 11$

Analytical Methods. 14

Process Waters 16

Ground Water Samples $\quad 19$

0il Samples $\quad 21$

Gas Samples , , 22

Spent Shale Core Samples $\quad 24$

Leachates from Spent Shales 28

Shale 0il Paraffins . $\quad 29$

Further Analytical Requirements $\quad 29$

$\begin{array}{ll}\text { Summary } & 29\end{array}$

References . . . . . 32

3. Leaching Studies of Occidental Room 3E Retorted Shale Samples

Introduction $\quad 33$

Objectives : : $\quad 33$

University of Colorado $\quad 35$

Los Alamos Scientific Laboratory $\quad 42$

Battelle-Pacific Northwest Laboratories 45

General Conclusions $\quad 52$

References $\quad 53$

4. Health Effects 54

Introduction $\quad 54$

Industrial Hygiene Data $\quad 54$

Biological Studies $\quad 61$

Human Health Studies $\quad 78$

Summary $\quad 79$

$\begin{array}{ll}\text { Prospective Studies } & 79\end{array}$

Appendix A:

Processing History of Retort 3E That May Affect The 3E-1 Core Samples by Occidental 0il Shale. Inc. 


\section{FIGURES}

Chapter 2 -- Characterization

1. Simplified flow diagram and sampling points for 0xy Retort 6 (not to scale).

2. Normal-alkane patterns in shale oils and crude petroleums.

Chapter 3 -- Leaching

1. XRD peak heights (in inches) of minerals found in the spent shale cores, from the top to the bottom of Retort 3E, Logan Wash site, Colorado

2. Retort $3 E$ Spent Shale Leachate Sample Correlation

3. Elution profile of organic carbon, salts, and $\mathrm{pH}$ from Occidental core sample, Retort $3 E 1,454-457$ feet

4. Soluble organic carbon as a function of core depth.

Chapter 4 -- Health Effects

1. Sampling locations on the control room level

2. Scanning electron micrograph of the dense, compact particles ( $x$ 2000).

3. Scanning electron micrograph of the larger, loose amorphous particles ( $x$ 2000).

\section{TABLES}

Chapter 1 -- Introduction

1. The 0il Shale Task Force Members

2. Advisory Group Members

3. Attendees - DOE/EV MIS Task Force Workshop July $11-12,1979$

Chapter 2 -- Characterization

1. Sample Collection

2. 0xy Retort 6 Product Water -- Collected March 6, 1979 / Data by Pacific Northwest Laboratory and University of Colorado 


\section{TABLES}

Chapter 2 -- Characterization

2A Comparison of Three Retort Waters Preliminary Data (in ppm)

3. Oxy Retort 6 Steam Boiler Blowdown Collected March 6, 1979 (in ppm except as noted)

4. Preservation of Ground and Stream Water Samples at Logan Wash

4A Analysis of 0xy Ground Water Wells Preliminary Data (in ppm)

5. 0xy Retort 6 Product 0il -- Preliminary Data (in ppm except as noted)

6. Comparison of Two Shale 0ils and Composite of North American Petroleum (in ppm except as noted)

7. Mercury in Offgas from 0xy Retort 6 Preliminary Data (in $\mu \mathrm{g} \mathrm{Hg} / \mathrm{m}^{3}$ gas)

8. Arsenic Speciation in Offgas from Oxy Retort 6 Prel iminary Data (in $\mu \mathrm{g} / \mathrm{m}^{3}$ )

9. Boron and Fluoride in Oxy Retort $3 E$ Spent Shale

10. Analyses of Core Samples From Oxy. Retort 3E Preliminary Data (in ppm except as noted)

11. Mineralogical Analyses for Selected Samples of Oxy Retort 3E Spent Shale Core

12. Analysis of Drilling Agents Used in the Recovery of Occidental 0il Shale Spent Shale R3E1

(in ppm except as noted)

Chapter 3 -- Leaching

1. Designation and Distribution for Occidental Retort 3E Shale Core Samples

2. Conditions and Parameters for Column Leaching Studies

3. Variation of Conductivity and $\mathrm{pH}$ with Number of Pore Volumes of Leachate from Each Column

4. Concentrations of Dissolved Species in First Pore Volumes from Composite Columns of Occidental Retorted Shale

5. Boron and Fluoride in 0xy Retort 3E Spent Shale

6. Grain Size Distribution and Specific Surface Area of Occidental Retorted $0 i 1$ Shale (R3El)

7. Electrophoretic Mobility (Micrometers/sec per volt $/ \mathrm{cm}$ ) and Zero Point of Charge of Occidental Retorted 0il Shale (R3E1): Room Temperature 
Chapter 3 -- Leaching

8. Trace Element Analyses for Leachates From 0xy's Retort 3E Samples ( $\mu \mathrm{g} / \mathrm{m} \ell$ )

9. Characterization of Carbon in Occidental Core Samples

10. Comparison of Concentration Range of Macro

Ions Found in the First Fraction of Leachates

from Occidental's Core Samples and Aboveground Retorted Shale

11. Comparison of Organic Carbon Leached from Occidental Core Samples and Above-ground Retorted Shale under Aerobic and Anaerobic Conditions

12. Summary of the Mineralogy/Chemistry of Oxy Retort 3E

Chapter 4 -- Health Effects

1. Particle Size

2. Occidental Andersen Impactor Samples

3. High Volume Samples (Loadings estimated from gross filter samples)

3 A High Volume Air Samples

4. Airborne Dust Concentrations

5. Salmonella/Liver Microsome Histidine Reversion Test TA 98 Tester Strain

6. Salmonella/Liver Microsome Histidine Reversion Test

7. Mutagenicity of Crude and Hydrotreated Shale $0 i 1$. Products and their Water Extracts

8A Ames Assay Data Comparing the Mutagenicities of Several Shale 0ils, a Coal Distillate and Two Crude Petroleums

8B Ames Assay Comparison of Subfractions Obtained By Solvent Extraction of Shale 0ils and a Coal Distillate

8C Ames Data for Occidental Crude Pnoduct Shale 0 il and Occidental Sludge 0i1: Unfractioned Crude Materials

8D Ames Assay of LH20 Column Fractions of Several Shale 0ils and a Coal Distillate

8E Recovery of Material after LH20 Column Chromatography Column Fraction

9. Mutagenicity of Shale $0 i 1$ and Water Extracts of $0 i 1$ Produced by the Occidental Modified In Situ Process 
TABLES

Chapter 4 -- Health Effects

10. Mutagenicity of . Shale $0 i 1$ and Water Extracts Produced By an Above-Ground Retorting Process

11. Mutagenicity of Waters Derived from the Occidental Modified In Situ Shale 0il Process

12. Mutagenicity of Retort Water and Crude Shale $0 i 1$ Derived By an Above-Ground Retorting Process

13. Mutagenicity of Column Leachates from 0ccidental R3ED Core Samples 


\section{INTRODUCTION}

The purpose of this report is to describe the preliminary results of an extensive research effort being carried out by researchers funded by the Department of Energy (DOE) on the environmental and health effects of extracting oil from oil shale by the modified in situ (MIS) process. This work involves the study of solid, liquid, and gaseous samples collected from the Occidenta1 0il Shale, Inc. (Oxy) site at Logan Wash in Colorado. This is the first intensive environmental research program on an MIS field demonstration. This research has been a joint effort involving DOE contractors, the State of Colorado, and Occidental Oil Shale, Inc.

It is important to note that much of this data has to be considered preliminary. Many analyses are not completed. Additional data is now being produced that will show how the results vary with time. These results will play an important role in defining future activities. Therefore, while the data gives indications of what to expect and where research needs to be done, it is not a definitive statement of what to expect from a MIS process.

\section{BACKGROUND}

On May 8, 1978 Governor Lamm of Colorado wrote the Secretary of Energy requesting "that the Department assist Colorado by working with us in developing additional research and analysis of current and future (oil shale) efforts." On May 26, 1978 the Acting Assistant Secretary for Environment (ASEV) of the Department of Energy responded by forming a Task Force, which at that time was designated the ASEV Modified In Situ (MIS) Task Force. The Task Force consisted of representatives from various national laboratories, the University of Colorado, and the Colorado Department of Natural Resources. The purpose of the Task Force was to plan, implement, and coordinate a comprehensive, integrated research program to assess the environmental and health effects of MIS processes. More recently the charge of the Task Force has been broadened to include all oil shale technologies and the name of the Task Force has been simplified to The Oil Shale Task Force.

The present membership of the Task Force is given in Table 1 . Most of these individuals have been involved with oil shale research projects funded by DOE. Robert Siek has served as the State of Colorado representative. The Chairman of the Task Force, Willard R. Chappe11, reports to Ralph Franklin who is the Coordinator of Oil Shale Research and Development for the Office of Environment (EV), Department of Energy. Arthur Hartstein is the Oil Shale Program Manager for the Office of Fossil Energy (FE) of DOE which is partially funding the technology research being carried out by Occidental at Logan Wash. The work with Occidental is coordinated with Arnold Harak, Technical Project Officer, Laramie Energy Technology Center. Jack O'Brien provides DOE/EV liaison at the regional level. 
TABLE 1

The Oil Shale Task Force Members

Willard R. Chappe11, Chairman University of Colorado at Denver Denver, Colorado

David Farrier Laramie Energy Technology Center Department of Energy Laramie, Wyoming

Phyllis Fox Lawrence Berkeley Laboratory Berkeley, California

Jonathan Fruchter

Darryl Hessel:

Richard Pelroy

Raymond Wildung

Batte1le-Pacific Northwest

Laboratories

Richland, Washington
Walter Hecox*

State of Colorado

Department of Natura1 Resources

Denver, Colorado

L.M. Holland

Marvin Tillery

George Voelz

Paul Wagner

Los Alamos Scientific Laboratory

Los Alamos, New Mexico

Richard Ragaini

Hector Timourian:

Lawrence Livermore Laboratory

Livermore, California

Robert Siek

Council of Energy Resource Tribes Englewood, Colorado
DOE Project Managers

Ralph Franklin, Ecological Research and RED Coordinator

Joseph Blair, Human Health Assessments

Gerald Goldstein, Pollutant Characterization and Safety Research

Charles Grua, Environmental Control Technology

David Smith, Health Effects Research Office of Environment

U.S. Department of Energy

Washington, D.C.

\section{Technical Staff}

John Lanning

Carol Nieuwenhuis

University of Colorado at Denver

Denver, Colorado
DOE Liaisons

Arnold Harak Laramie Energy Technology Center Laramie, Wyoming

Arthur Hartstein Office of Fossil Energy U.S. Department of Energy Washington, D.C.

Jack O'Brien Denver Project Office Lakewood, Colorado

* Replaced Robert Siek as the State of Colorado Representative in December, 1979. 
TABLE 2

Advisory Group Members

Merril R. Coomes

Carol R. Edmonds

Rosielea Gash

Bobby J. Gunther

John Hutchins

Glen A. Miller

Rafael Moure

Paula Phillips

Martin Robbins

Alan Sašs

Terry Thoem.

Anne V. Vickery
TOSCO Corporation, Los Angeles, California

Colorado House of Representatives, Denver, Colorado

Rio Blanco Oil Shale Company, Denver, Colorado

U.S. Public Health Service, Denver, Colorado

Energy Development Consultants, Inc, , Golden, Colorado

U.S. Geological Survey, Grand Junction, Colorado

0il, Chemical \& Atomic Worker Int'1. Union, Denver, Co.

Environmental Defense Fund, Denver, Colorado

Colorado Energy Research Institute, Golden, Colorado

Occidental Oil Shale, Inc., Bakersfield, California

Erivironmental Protection Agency, Denver, Colorado

Colorado Mountain Club, Boulder, Colorado 


\section{THE MIS PROCESS}

The Oxy modified in situ process is described in Appendix A. Briefly, it consists of mining out $20 \%-40 \%$ of the oil shale to create a void. Holes are then drilled into the adjacent rock and filled with explosives. When detonated, rubblized shale fills the total retort volume (thus distributing the void throughout a given volume of oil shale). The retort is then ignited. Condensed oil and water are collected near the bottom of the retort.

Occidental has carried out six retorting experiments at Logan Wash. Retort 6 was ignited in September of 1978 and burned until the summer of 1979. This report describes the results on samples collected from Retort 6 and on retorted shale collected by the coring of Retort 3E, an older retort which has had time to cool.

\section{RESEARCH AREAS}

While a considerable body of data now exists for surface processes, very little environmental research on the MIS process had been done prior to the effort by the Task Force. Most of the previous work had involved samples obtained from simulated MIS processes at Lawrence Livermore Laboratory and the Laramie Energy Technology Center. While this previous work was valuable, it is essential to obtain data from field demonstration projects to test the validity of the laboratory retort samples. Moreover, since there is much more control of the process in the laboratory simulated MIS retorts, it can be expected that conditions will vary over a much larger range in the field than in the laboratory. In order to fully understand the environmental effects of the processes it is essential to know the nature of the variations with time and various process parameters.

Because of the nature of the MIS process certain environmental aspects stand out over others as potentially important and perhaps significantly different from surface processing. These include:

- Changes which may occur in groundwaters that come into contact with the retorted shale left underground and subsequent leaching of soluble materials from the spent shale.

- The emission into the atmosphere of different types of elements or com-

- pounds and/or at different rates than for surface processes.

- The associated production of large quantities of product water which is subsequently separated from the oil and is of poor quality. Also of interest is the production of large quantities of poor quality water from the dewatering wells.

- The contamination of rainwater and snow melt by substances leached from the surface disposal or storage piles of the mined-out raw shale.

- Potential adverse impacts on worker health associated with accidents and exposure to liquid, gaseous, and solid materials of a different nature than encountered in mines associated with surface processing. 
The above list is not all-inclusive and additional important issues may be anticipated to surface as development proceeds. It is important to note that the lean shale characteristics of the Logan Wash research facility have thus far precluded plans for commercial development. Certain types of research were considered to be of lower priority or inappropriate to carry out for the Logan Wash operation because of its small size (i.e. socio-economic impact) and/or site (location on the periphery of the Piceance Basin). These research activities will be carried out at a later date on commercial-sized MIS operations. Studies of mine water, raw shale leachate as well as hydrologic modeling are examples of avenues for future research.

As a result of an intensive planning process to determine those research areas that were most significant and most appropriate for the operation, the Task Force decided to focus its initial efforts at Logan Wash on three major topics:

- Characterization of the physical and chemical nature of the effluents and products from Retort 6 and of the spent shale from Retort 3E.

- Determination of the chemical nature of leachates from the retorted shale.

- Determination of the nature and magnitude of potential effects on the health and safety of any humans who might be exposed to the product or any associated effluents or safety hazards associated with the process.

Characterization studies provide the basis for understanding the subsequent health and environmental effects of oil shale retort products and effluents. The chemical analysis of these materials indicates which contaminants may be of significance and which are not likely to be important. This allows the investigators who are developing control strategies to focus their efforts on the important problem areas. In order to accomplish this task a rather comprehensive sampling program was envisaged and is described in Appendix B of the "ASEV Modified In Situ Task Force Research Plan for Occidental Oil Shale, Inc.", written by the Task Force.

The materials sampled and the locations of the sampling points are described in the Characterization chapter (Chapter 2). While the previous work on simulated in situ retorts gave some indications of which contaminants to look for, analyses were performed for a large number of substances because of anticipated differences between the laboratory and the field experiments. Moreover, samples were preserved in many different ways because the researchers wanted to determine the optimum methods for future activities.

In addition, previous studies of simulated in situ retorts have shown that emission rates can vary substantially during the course of a burn. For example, mercury, cadmium and certain organic species appear to condense or react with the shale in the cooler regions of the retort. These constituents may be subsequently leached by groundwater or they may be volatilized by the advancing flame front and emitted from the retort in a large pulse towards the end of the retorting period. To test this possibility, it is necessary to periodically sample the gases, product water, and oil. 
The samples from Retort 6 were collected by personnel from the DOE Environmental Measurements Laboratory and Occidental Oil Shale, Inc. under the direction of Dr. Fruchter from Pacific Northwest Laboratories. Dr. Fruchter is the Sample Coordinator for the Task Force. The samples of the spent shale from Retort 3E were previously obtained by personnel from Occidental Oil Shale, Inc. and were mailed to the Task Force and given to Dr. Fruchter. Dr. Fruchter then sent samples of the materials to the participating researchers from the University of Colorado, Lawrence Livermore Laboratory and Los Alamos Scientific Laboratory. The results of the chemical and physical characterization of some of these samples are given in the Characterization chapter.

It is important to note that because of the complex chemical nature of these materials many "standard" methods for chemical analysis do not work for these samples. As a result, part of the research by the Task Force involves developing new techniques, or modifying old techniques of analysis. Thus, some answers will not be available until these techniques are developed.

Leaching studies are designed to determine the types of constituents that can be released from a solid (or liquid) material such as spent shale upon contact with water. More importantly, since every material is soluble to some degree, these studies determine the rates at which various materials can be leached from spent shale and therefore are important first steps in determining whether groundwater will be significantly contaminated if it reintrudes into the burned-out retorts. There are many other data that have to be obtained before a final determination of the risk of such contamination can be made. For example, contaminants released into water by spent shale may be taken out of solution as the water passes through the surrounding raw shale material, thus eliminating any potential for environmental damage. Studies on the transport of contaminants through aquifers are complex and adequate models of this transport are not yet available.

Before a contaminant can be transported, it must be released and the rates of release and concentrations can be determined by contacting the material with water. This can be done in several ways.' One method involves passing water through a column of the material and collecting it at the other end of the column; and another involves mixing the material with a given amount of water for a given period of time and then separating the water from the material. The first test might be considered a "dynamic" test and the other a "static" test. The dynamic test more closely simulates the field situation of groundwater moving through the burned-out retort, while the static test might be considered a worst case situation because the water remains in contact with the material for a longer time thus giving a greater opportunity for release.

As any given contaminant is released there is less available for subsequent release. Thus, in general, one expects with the column or dynamic studies to find that as additional water is passed through the concentration of that contaminant will generally decrease with time. The rate of this decrease however, can vary widely from one contaminant to the next. A considerable amount of leaching data exists for the surface processes. For some parameters such as total dissolved solids (TDS) there is a considerable reduction after the passage of one pore volume (a volume of water equal to the volume contained in the pores of the material) of water. For other parameters, such as fluoride (F), researchers have found that as many as forty pore volumes are required before a significant decrease in the concentration of fluoride is observed. 
Such behavior has significant importance with respect to control technologies. If it is determined that all contaminants of significance can be reduced to acceptable levels by passing a relatively small volume of water through the burned-out retorts, then one strategy is to deliberately leach the material, collect the leachate and either remove the contaminants from the water or evaporate the water. Either approach leaves a solid waste disposal problem that is easier to solve than the decontamination of groundwater. If important contaminants require large volumes of water then a different strategy is needed. One such strategy is to prevent groundwater from making contact with the retorted shale by surrounding it with a wall of impermeable material or adding materials that will make the spent shale impermeable.

Thus, leaching studies go a step beyond the characterization of the spent shale. The leaching studies tell which constituents in the spent shale are soluble and how soluble. It is only the soluble constituents that can pose a possible hazard to the environment or human health since the insoluble ones stay with the spent shale.

Thus, leaching studies are required to indicate if the burned-out retorts pose a hazard to the large groundwater aquifers in the Piceance Basin. Some researchers have proposed that the higher temperatures obtained in the MIS process compared to surface processes will lead to the formation of very insoluble minerals. Others dispute this claim. Leaching studies of field-generated materials are necessary to resolve this controversy.

The leaching studies relate back to the characterization studies in that chemical analyses of the leachates are required. As with other materials, methods for the analysis of some constituents are still being developed, thus requiring additional research before the materials can be fully characterized. In addition, there are controversies over methods of carrying out the leaching studies.which include which waters (deionized or local aquifer water) to use, how fast to pass it through, whether to grind the sample or not and how finely, and how to prepare the column for leaching. These controversies all have valid concerns at their base. For example, as time passes, the chemical nature of the retorted shale will change due to contact with its surrounding environment. This in turn will change the nature of the leachate. Because groundwater moves very slowly it may take sixty years for one pore volume to pass through a burned-out retort. How may actual field conditions be simulated in the laboratory in a timely fashion to help design control strategies for plants which may come on-1ine in the mid-1980's? This problem is an active area of research by the Task Force.

Health studies are the endpoint of research as far as the exposure of humans is concerned. While characterization studies tell how much of a contaminant is there and leaching studies indicate how much is released and at what rate, health studies are required to see if exposure to these materials at the levels anticipated is likely to cause an adverse impact. Such studies are complex, often long term, generally difficult to interpret, but essential in order to devise strategies for minimizing adverse health impacts. 
The health studies include the characterization of the materials and effluents released to the environment ( which are obtained from the characterization studies') and the types and magnitudes of exposure. Because of the complex mixtures involved, previous experience with individual contaminants may not be adequate due to antagonistic or synergistic effects. In addition, for many contaminants, adequate data may not exist on health effects. Thus, biological testing is required. In addition, animal studies are never entirely adequate because of species differences. Thus, both retrospective and prospective human studies are needed to completely validate the results thus far obtained.

In general the biological studies involve collecting samples of products and effluents, characterizing their physical and chemical nature, characterizing the exposure levels, and finally exposing test systems, either cells or whole animals, to the materials at concentrations that have some relationship to the anticipated exposure levels. Because long-term animal studies are expensive and require physical resources (e.g., inhalation chambers) that are limited in number, a pragmatic testing program is required that reserves the expensive, long-term tests for those materials which carry some possibility for human contact and which are the most biologically active as indicated by less expensive short-term tests.

Thus, the general strategy of the program is to carry out short-term, inexpensive tests on all types of materials, then take those showing significant effects in these tests and subject them to long-term animal tests where we expect a better correlation with human effects. The problem is that the short-term tests are mostly in vitro tests using cells and are not perfectly correlated with what happens in whole animals. Other short-term, high-dose toxicity tests on animals give some indication of health effects but may not show what to expect from longterm, low-level exposure.

One such in vitro test is the Salmonelza histadine inversion test developed by Bruce Ames. This test, which is fast and relatively inexpensive, gives a measure of the mutagenic activity of materials. Because many mutagens are carcinogens and vice versa, it also gives an idea of, the carcinogenic potential of the material. It is not perfect, however, because some known carcinogens (such as certain metal compounds) are not mutagenically active by the Ames test and some materials that are active by the test do not cause tumors in animal studies. However, the correlation is quite good and the test is a very valuable screen. Certainly those materials showing a significant activity by the Ames test should be subjected to whole animal testing to see if they cause tumors.

One very practical use for the Ames test is that a complex mixture when shown to be active can be chemically fractionated in different classes of compounds and these fractions can be tested. If one fraction contains most of the activity it can be further fractionated and tested. In this way there is the possibility of identifying the substance or substances responsible for the activity and developing treatment strategies to remove them. This can only be done because the test is fast and inexpensive. However, once the responsible substance or group of substances is identified animal tests can and should be performed to see if tumors are actually produced. 
Because there are many different endpoints (mutagenicity, toxicity, etc.)

more than one test is required to cover the spectrum of possible effects. This is true with both the in vitro and the in vivo tests: In addition, there are often two or more tests for a given endpoint, and because of the complexity of biological systems it is often worthwhile to use more than one test.

Human studies require even more time than animal studies and must be carefully designed. A study protocol for the Occidental workers is being designed.

It is important to note that the Task Force is not covering every possible hazard to human health in this study. For example; worker safety is an important issue, but the Logan Wash site is not very appropriate because of the small size of the operation. The Task Force will do these studies at other, more appropriate sites (e.g., Tract C-a). Also, there will be health problems related to the socio-economic impacts (e.g., mental health), again the operation at Logan Wash doesn't offer a good opportunity for this type of research.

\section{WORKSHOP}

The first draft of this report was the result of a Task Force Workshop held on July 11 and 12, 1979 in Denver. The researchers reported on their results and then worked in groups corresponding to the three study areas, Characterization, Leaching, and Health to compare, discuss, and interpret the data. The chairmen of the three groups then worked with the Task Force members to prepare subsequent drafts. Scientists from Occidental Research Corporation, a subsidiary of Occidental Petroleum, Inc., and the U.S. Geological Survey were present as resource people. The individuals who participated in the Workshop are listed in Table 3 . The Workshop provided an opportunity for critical review, consensus or disagreement, and synthesis.

While this report contributes to the state of knowledge of the MIS process, it is not a definitive study which would allow extrapolation of results to a commercial-sized operation or even a commercial-sized retort. As more analyses are completed and as independent verification of results is obtained, problems associated with commercial operations may be better anticipated. 
TABLE 3

Attendees

DOE/EV MIS Task Force Workshop

July $11+12,1979$

Corale Brierley

Willard R. Chappe11

Mary Ann Caolo

Jonathan Fruchter

Thomas Garland

Alice Hardigree

L. M. Hol1 and

Everett A. Jenne

Mathilda Kland

John Lanning

Robert Meglen

Jack O'Brien

Won Park

Richard Pelroy

Peter Persoff

Kathy Petersen

Richard Poulson

Dick Ragaini

Jon Rudnick

Donald Runne11s

Ola Saether

Robert Sievers

Dale Spall

Kenneth Stollenwerk

Terry Tedeschi

Robert Thomason

Marvin Tillery

Hector Timourian

Paul Wagner

Raymond Wildung

Joe1 Williams

John Zachara
New Mexico Bureau of Mines, Socorro, NM

University of Colorado at Denver

University of Colorado at Boulder

Pacific Northwest Laboratories, Richland, WA

Pacific Northwest Laboratories, Richland; WA

Oak Ridge National Laboratory, Oak Ridge, TN

Los Alamos Scientific Laboratory, Los Alamos, NM

U. S. Geological Survey, Menlo Park, CA

Lawrence Berkeley Laboratory, Berkeley, CA

University of Colorado at Denver

University of Colorado at Boulder

Department of Energy, Lakewood, CO

Occidental Research Corp., Irvine, CA

Pacific Northwest Laboratories, Richland, WA

Lawrence Berkcley Laboratory, Berkeley, CA

University of Colorado at Denver

Laramie Energy Technology Center/DOE, Laramie, WY

Lawrence Livermore Laboratory, Livermore, CA

Los Alamos Scientific Laboratory, Los Alamos, NM

University of Colorado at Boulder

University of Colorado at Boulder

University of Colorado at Boulder

Los Alamos Scientific Laboratory, Los A1 amos, NM

University of Colorado at Boulder

University of Colorado at Boulder

Occidental Oil Shale, Inc., Grand Junction, CO

Los Alamos Scientific Laboratory, Los Alamos, NM

Lawrence Livermore Laboratory, Livermore, CA

Los Alamos Scientific Laboratory, Los Alamos, NM

Pacific Northwest Laboratories, Richland, WA

Los Alamos Scientific Laboratory, Los Alamos, NM

Pacific Northwest Laboratories, Richland, WA 
Chapter 2

CHARACTERIZATION

\section{INTRODUCTION}

Characterization of samples from Occidental oil Shale, Inc.'s (Oxy) Retorts $3 \mathrm{E}$ and 6 at the Logan Wash site has been carried out by scientists at Pacific Northwest Laboratories (PNL), Los Alamos Scientific Laboratory (LASL), and the University of Colorado (CU). A combination of wet chemical and instrumental techniques has been used including $x$-ray fluorescence (XRF), neutron activation analysis (NAA), DC plasma emission spectroscopy, atomic absorption, scanning electron microscopy coupled with energy dispersive $x$-ray fluorescence, the NIOSH extraction procedure for total hydrocarbons, colorimetric procedures with gas diffusion, and other colorimetric techniques.

There are several objectives of the characterization task. They include collection and distribution of samples, determination of the physical forms and chemical compositions of effluents and products of Occidental Oil Shale's Retort 6 , determination of the chemical species of certain samples, and determination of the variation of composition of effluents from the retort as a function of time. Additional goals are to improve analytical procedures where necessary and to maintain a program of quality control and technique verfication.

It must be stressed that these data represent preliminary results. The data are subject to change, not all samples have been analyzed, and independent verification of many results is lacking. In addition, only the first suite of samples from Retort 6 has been analyzed, thus any time profile of the burn from Retort 6 will have to await further sample analyses. Nevertheless, there are significant findings in the preliminary results which are presented in the following figures and tables. Any interpretation of results from these preliminary data is, however, thus limited to the above restrictions.

\section{SAMPLE COLLECTION AND PRESERVATION}

Collection of the samples was carried out as a coordinated effort by Pacific Northwest Laboratory, Environmental Measurements Laboratory (DOE), Los Alamos Scientific Laboratory, and Occidental Oil Shale, Inc. A major sampling effort was carried out the week of March 5, 1979 by personnel from PNL, EML, and. LASL. During this week a large number of samples was obtained from various effluent points at the retort. These points are illustrated in Figure 1 which is a very simplified schematic of Retort 6 . The samples collected are listed in Table 1 . In addition, during this period, personnel from oxy were trained in the various collection techniques so that they could continue sampling of the retort during the reslainder of its burn time. These occidental personnel continued sampling of the retort on a periodic basis through July 1979.

Since many of the samples are chemically or physically unstable, some of the samples wore analyzed un site, particularly mercury and sulfide samples. In 


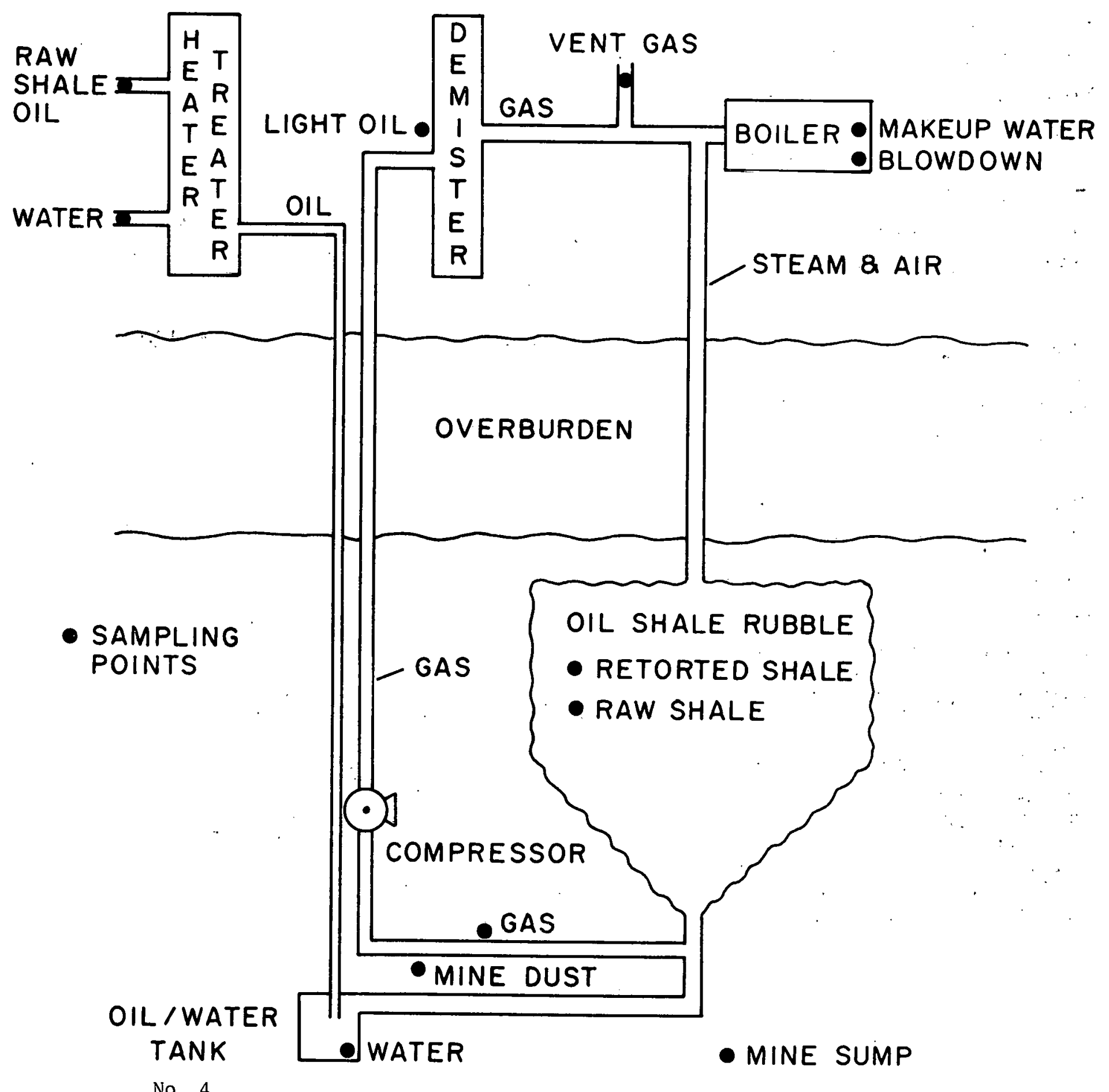

Figure 1. Simplified flow diagram and sampling points for oxy Retort 6 (not to scale). 
TABLE 1

Sample Collection

Crude Oil -- collected from heater-treater

Light 0il - collected from retort offgas treatment pilot plant

Product water - collected from oil-water separation tank \#4 (produced by the retorting process)

Boiler Blowdown -- collected from steam injection boiler

Makeup Water -- water used to make steam, collected at steam injection boiler

Mine Sump Water -- collected from mine sump (water that naturally flows into the mine from the bedrock aquifers and is subject to contamination by mining activities, i.e., blasting, vehicle traffic, etc.)

Groudn Water -- collected from bedrock wells LW 106 and LW 108 and alluvial, well. LW 101

Water from old Retorts -- retorts 1-5

Retort Gas ( $\mathrm{Hg}, \mathrm{As}, \mathrm{F}^{-}, \mathrm{H}_{2} \mathrm{~S}, \mathrm{Rn}$, Organics) -- collected from offgas line, product leve1, vacuum side of compressor

Mine Air -- collected from product and air levels

Mine Dust -- collected from product and air levels

Spent Shale Core -- collected from Retort 3E -

addition, considerable attention was paid to sample preservation where it was necessary to ship samples back to the laboratory. Liquid samples were immediately cooled by refrigeration and returned in sealed, dark. Teflon containers which were maintained using ice at low temperature to minimize sample deterioration. Once received at Pacific Northwest Laboratory the samples were also maintained at a temperature of $4{ }^{\circ} \mathrm{C}$ and in the dark. Head space over oil samples was flushed with nitrogen in order to prevent oxygen from reacting with the samples. : Water samples were divided on site and the subfractions were filtered through $0.4 \mu$ Nucleopore membrane filters, acidified, or preserved by other methods depending on the analysis to be performed. In addition, in most cases blanks were carried through the entire procedure to ascertain that no contamination of the samples occurred during sampling or handling. 
ANALYTICAL METHODS

Neutron Activation Analys is

\section{Battelle Pacific Northwest Labosatories}

In the PNL procedure, 0.1 to $0.5 \mathrm{~g}$ of sample were weighed into $0.4 \mathrm{dram}$ polyethylene vials; the vials were then heat sealed. The 0.4 dram vial was placed in a 2-dram polyethylene vial which was also heat sealed. After irradiation,..: the samples were transferred to fresh vials. Standards used for elemental analysis were Fischer atomic absorption standards for arsenic, nickel, zinc, and. selenium; National Bureau of Standards' orchard leaves (SRM 1571); U.S. Geological Survey's standard rocks BCR-1, W-1, AGV-1, and PCC-1; and IAEA's standard Soil-5. Samples were irradiated at the Oregon State University reactor at a power level of $1 \mathrm{MW}$.

Triplicates were analyzed and the reported errors are the larger of 1 standard deviation for the replicates, 1 standard deviation from the counting statistics, or $2 \%$ of the reported value. The analysis procedure used one irradiation period and two decay/counting intervals. Following the irradiation, the samples were transferred into clean polyethylene vials and counted on an $80-\mathrm{cc}$ Ge(Li) detector with a resolution of $1.96 \mathrm{keV}$ at $12 \%$ relative efficiency after the seven day cooling period. Counting following the six week cooling period was done on a anticoincidence-shielded $\mathrm{Ge}(\mathrm{Li})$ detector to reduce Compton background for low- and medium-energy gamma rays, and in some cases, to remove peak interferences from correlated gammas.

\section{X-ray Fluorescence Spetrometry}

\section{Battelle Pacific Northwest Laboratories}

Three replicates were analyzed. The reported errors are 1 standard deviation for the three analyses. Samples were prepared by pressing $0.250 \mathrm{~g}$ of powder and an equal weight of cellulose into a $3.2 \mathrm{~cm}$ diameter disc. The samples were analyzed on a Kevex Model 810 energy-dispersive $x$-ray machine. System resolution was $200 \mathrm{eV}$ at $6.4 \mathrm{keV}$ ( $\mathrm{Fe} \mathrm{K} \alpha \mathrm{x}$-ray). Excitation was provided by a zirconium or silver secondary source. The $x$-ray tube was operated at $50 \mathrm{kV}$ with a current of $35 \mathrm{~mA}$. The resulting radiation was measured with an $80 \mathrm{~mm}^{3}$ detector and a 1000 channel pulse height analyzer. Counting time was 100 minutes. The elements analyzed were silicon, chlorine, potassium, calcium, titanium, vanadium, chromium, manganesề, iron, cobalt, nicke1, copper, zinc, gallium, mercury, selenium, lead, arsenic, bromine, rubidium, uranium, strontium, yttrium, zirconium, niobium, and molybdenum. Individual calibrations were calculated for each sample matrix from backscatter intensities and a multi-element, thin sample calibration curve. 


\section{Atomic Absorption Spectroscopy}

\section{Battelle Pacific Northwest Laboratory}

Atomic absorption spectroscopy was used to measure aluminum, calcium, iron, mercury, potassium, magnesium, sodium, silicon, strontium, and titanium. Conventional flame atomic absorption was used for all elements except mercury which was determined by flameless atomic absorption. Measurements were made with a Perkin Elmer 403. Powdered samples were fused with lithium metaborate using a 6:1 $\mathrm{LiBO}_{2}$ sample ratio. The fused sample was dissolved in concentrated nitric acid and diluted to $200 \mathrm{ml}$. Commercially prepared aqueous standards were used. USGS standard rock BCR-1 was used as a control.

Mercury was determined using a flameless technique. A 50 to $150 \mathrm{mg}$ sample was combusted, the vapors swept into a separation train, and the mercury trapped on gold beads and analyzed by flameless AA. In the separation train, mercury-free air was introduced into a $950^{\circ} \mathrm{C}$ quartz tube containing the sample overlying a layer of 3 to $4 \mathrm{~cm}$ of golld coated quartz beads. The higher temperature and oxidizing conditions volatilized the mercury from the sample matrix and the gold beads converted it to the elemental form. Elemental mercury was separated from interfering organic vapors by passing the sample gases through an alumina column which selectively retains the organic vapors but passes $\mathrm{Hg}^{\circ}$. The $\mathrm{Hg}^{\circ}$ was collected by amalgamation in a column of gold coated glass beads maintained at room temperature. This column was detached from the separation train and attached to a flameless AA system. Amalgamated $\mathrm{Hg}^{\circ}$ was released by heating the column to $500^{\circ} \mathrm{C}$ in a $\mathrm{N}_{2}$ gas stream. The $\mathrm{Hg}^{\circ}$ vapor was swept into a long-path-length gas absorption cell where it was measured by atomic absorption at $254 \cdot \mathrm{nm}$.

\section{Emission Spectroscopy}

\section{Battelie Pacific Northwest Laboratory}

PNLiused a dc plasma technique to measure boron. Three replicates were analyzed. The reported errors are 1 standard deviation for the three replicates. Samples were prepared by fusing $3 \mathrm{~g}$ of sodium carbonate with a $0.5 \mathrm{~g}$ sample, dissolving the residue in $8 \mathrm{M}$ nitric acid, and diluting to $100 \mathrm{ml}$. The samples were analyzed on a Spectrametrics Spectraspan III employing a dc argon plasma excitation system and an Echelle grating spectrometer.

\section{Selective Ion Electrode}

\section{Battelze Pacific Northwest Laboratory}

Selective ion electrode measurements for sulfide process waters were !made on site immediately after sampling to avoid any degradation of the sulfide. An Orion $\mathrm{Ag} / \mathrm{sulfide}$ electrode was used. An antioxidant buffer was added to the sample, and the sulfide was titrated with standardized lead acetate using a standard subtraction method. 
Molecular Absorption

\author{
University of Colorado (CU)
}

$\mathrm{CU}$ used molecular absorption of $\mathrm{AlF}$ in an air-acetylene flame to determine fluorine in a fused sample. The analytical method was developed by Tsundda, Fujiwara, and Fuwa, and was modified for oil shales by Meglen and Krikos. ${ }^{2}$

Fluorimetric and Colorimetric Methods

University of Colorado

CU used these techniques to measure silicon, selenium, molybdenum, and boron. Silicon was determined colorimetrically by the standard molybdenum blue procedure. Selenium was determined by a fluorimetric method which uses 2, 3diaminonaphthalene. Molybdenum was determined colorimetrically using potassium thiocyanate and boron was determined using an Azomethine-H method. The fusions and digestions used with these procedures have been previously described.

\title{
PROCESS WATERS
}

The Oxy" Retort 6 product water collected from oil-water separator tank No. 4 on March 6, 1979 was analyzed for a number of elements of environmental interest using a combination of analytical techniques. In several cases, the data were then compared with process waters from other oil shale processes--an aboveground process and another in situ process which does not use steam injection.

Table 2 presents quantitative elemental analysis and Table $2 \mathrm{~A}$ shows a comparison between Oxy Retort 6 water and two other oil shale processes. The two in situ waters are fairly similar except for boron and molybdenum. In the case of the boron concentrations, the high boron of the other in situ process water may be due to contamination by the local perched ground water which is quite high in. boron. The cause of the higher molybdenum in the other in situ process is not presently understood. Both of the in situ waters show considerable differences from the above-ground water. These differences may be due to several factors. First, the above-ground process is a continuous process and the in situ a batch process. Second, the above-ground process produces much less water than the in situ process. Because there is less water to dilute the water soluble species, certain of these constituents are more concentrated in the above-ground process water. Third, the in situ process operates at a higher temperature. Finally, the in situ waters may have a contribution from ground water. Keeping these factors in mind, the in situ waters are considerably lower than the above-ground water in total sulfur and calcium, and somewhat lower in arsenic. The boron concentration is similar in the loxy and above-ground water. Conversely, the Oxy water is much higher in sodium and molybdenum, and the other in situ process water is somewhat higher in fluoride than the above-ground process water. 
TABLE 2

Oxy Retort 6 Product Water -- Collected March 6, 1979

Data by Pacific Northwest Laboratory and University of Colorado (in $\mathrm{ppm}$ )

\begin{tabular}{|c|c|c|c|c|}
\hline & NAA & $\mathrm{XRF}$ & Other & \\
\hline Aluminum & $<1$ & & & \\
\hline Antimony & $0.018 \pm 0.008$ & & & \\
\hline Arsenic & $1.32 \pm 0.06$ & $0.87 \pm 0.01$ & & \\
\hline Boron & & & $12.6 \pm 0.5^{*}$ & $13.1 \pm 0.03+$ \\
\hline Bromine & $0.34 \pm 0.06$ & $0.28 \pm 0.04$ & & \\
\hline Calcium & & $0.72 \pm 0.43$ & & \\
\hline Chlorine & $232 \pm 9$ & $183 \pm 8$ & & \\
\hline Chromium & $<0.8$ & $<0.07$ & & \\
\hline Coba1t & $<0.2$ & $<0.02$ & & \\
\hline Copper & $<4$ & $0.03 \pm 0.01$ & & \\
\hline Fluoride & & & $34.8 \pm 1.0 \pi$ & \\
\hline Gallium & & $<0.01$ & & \\
\hline Iron & $<120$ & $0.19 \pm 0.02$ & & \\
\hline Lead. & & $<0.04$ & & \\
\hline Lithium & & & $1.80 \pm 0.05+$ & \\
\hline Magnesium & $<30$ & & & \\
\hline Manganese &,$<0.1$ & $<0.04$ & & \\
\hline Mercury & & & $<0.02^{* *}$ & \\
\hline Molybdenum & $0.3 \pm 0.1$ & & $0.257^{\prime}$ & \\
\hline Nickel & $<0.3$ & $<0.02$ & & \\
\hline Nitrogen & & & $1500 \pm 100 \pi$ ศ & \\
\hline Potassium. & & $36 \pm 2$ & & \\
\hline Selenium & $0.04 \pm 0.01$ & & & \\
\hline Silicon & & $<160$ & & \\
\hline Sodium & $2810 \pm 20$ & & & \\
\hline Strontium & & $0.57 \pm 0.08$ & & \\
\hline Sulfide & & & $112 \pm 15 \pi$ & \\
\hline Sulfur & $3100 \pm 870$ & $2720 \pm 150$ & & \\
\hline Titanium & & $0.53 \pm 0.07$ & & \\
\hline
\end{tabular}


TABLE 2 (continued)

\begin{tabular}{llll}
\hline & NAA & XRF & Other \\
\hline Uranium & $<0.06$ & & \\
Vanadium & $<0.04$ & $<0.12$ & \\
Zinc & $<0.2$ & $<0.1$ & \\
\hline
\end{tabular}

*

DC plasma emission spectroscopy

${ }^{\dagger}$ Colorimetric

"Selective ion electrode

** Cold vapor atomic absorption

${ }^{+\dagger}$ Conventional atomic absorption

${ }^{\pi T}$ Analysis by Schwarzkopf, Inc. (New York)

TABLE 2A

Comparison of Three Retort Waters

Preliminary Data (in ppm)

\begin{tabular}{lccc}
\hline & Oxy .- Retort 6 & In situ (no steam) & Above-Ground \\
\hline Arsenic & 1.3 & 2.5 & 4.9 \\
Boron & 13 & 150 & 12 \\
Chlorine & 230 & 130 & 90 \\
Copper & 0.03 & 4 & 33 \\
Fluorine & 35 & 26 & 10 \\
Molybdenum & 0.26 & 2.5 & 0.07 \\
Sodium & 2800 & 5100 & 93 \\
Sulfur & 2700 & 1100 & 17,000 \\
\hline
\end{tabular}

In addition, samples of blowdown from the steam injection boiler were obtained on March 6, 1979. This blowdown is significant because Oxy is using recycle product water in addition to creek water to generate steam for the retort. Thus, the blowdown is the actual waste stream which will have to be disposed of in an environmentally acceptable manner. Analysis by neutron activation of the blowdown sample., is given in Table 3 . 
Table 3

Oxy Retort 6 Steam Boiler Blowdown

Collected - March 6, 1979

(in ppm except as noted)

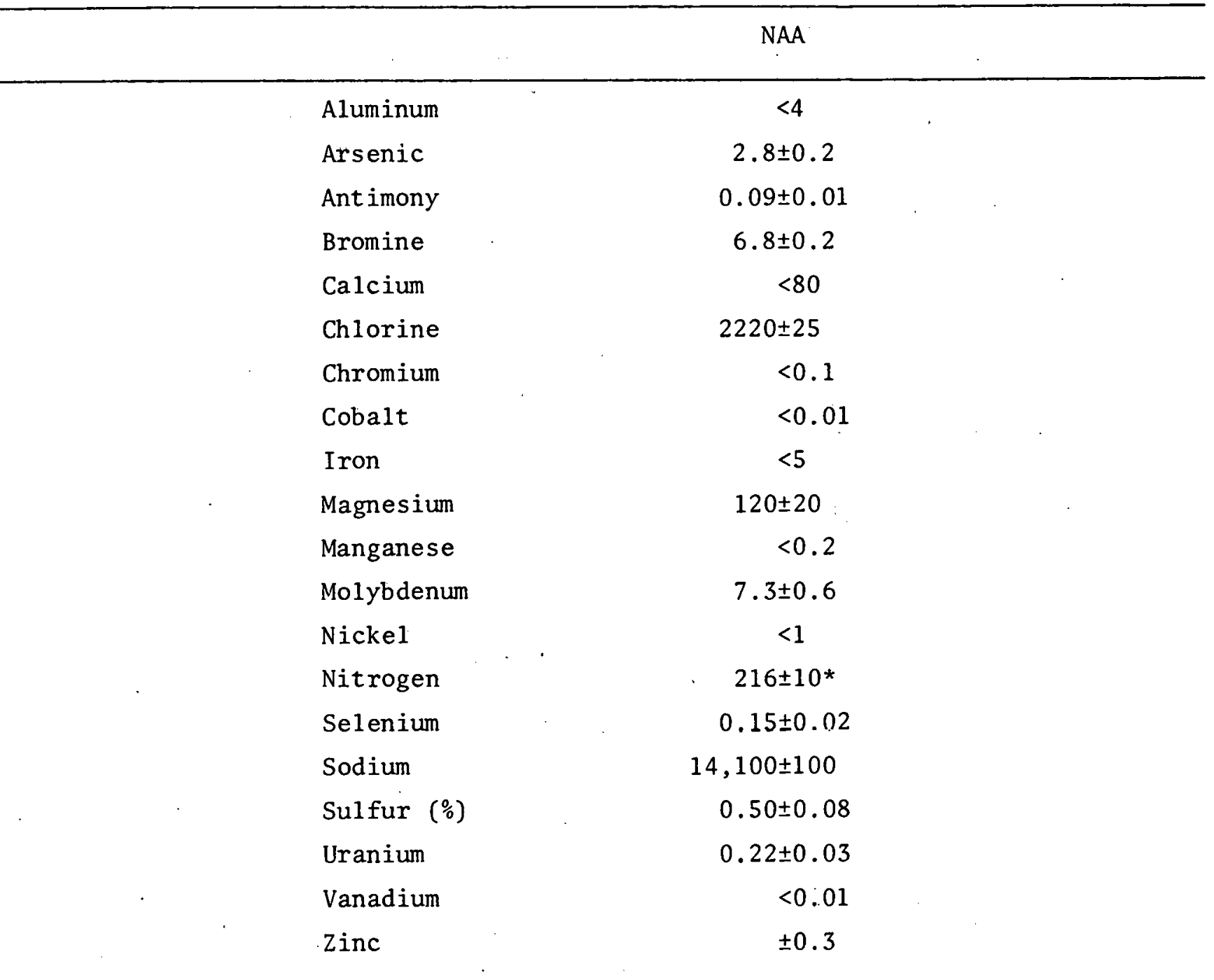

* Analysis by Schwarzkopf, Inc.

GROUND WATER SAMPLES

Water samples were obtained from three wells--LW 106, a bedrock well located about $200 \mathrm{~m}$ from Retort 6 site; LW 108, a we11 about $160 \mathrm{~m}$ from Retort 4; and LW 101, an alluvial well at the head of Logan Wash, at the base of the raw shale tailings pile. The samples were divided on site and different subfractions were treated by a standard sampling protocol as shown on Table 4. Comparison of the two bcdrock wells in Table 4A shows that LW 106, the well closest to the retorts, has a significantly higher concentration of a number of elements including boron, romine, chlorine, fluoride, lithium, sodium, and sulfur. The sulfur content, however, 
is still less than half that found in the alluvial well. It is interesting that the elevated elements in LW 108 do not occur in the same ratios as found in the product water from Retort 6 . Therefore; other factors may be operating in the elevation of these concentrations.

TABLE 4

Preservation of Ground and Stream Water Samples at Logan Wash

Samples collected in polyethylene bottles-filtered samples filtered through $0.4 \mu$ Nucleopore filters. Each sample was divided into seven subsamples treated as follows:

1. Filtered -- untreated, refrigerated

2. Filtered plus $5 \mathrm{~m} \ell$ Ultrex nitric acid

3. Filtered -- untreated

4. Unfiltered plus $5 \mathrm{~m} \ell$ concentrated sulfuric acid

5. Unfiltered plus $1 \mathrm{~g}$ copper sulfate plus $6 \mathrm{ml}$ concentrated phosphoric acid

6. Unfiltered -- untreated

7. Unfiltered plus $5 \mathrm{~m} \ell$ Ultrex nitric acid

TABLE 4A

Analysis of Oxy Ground Water Wells

Preliminary data (in ppm)

\begin{tabular}{lccc}
\hline & $\begin{array}{c}\text { LW 106 } \\
\text { (Bedrock) }\end{array}$ & $\begin{array}{c}\text { LW 108 } \\
\text { (Bedrock) }\end{array}$ & $\begin{array}{c}\text { LW 101 } \\
\text { (Alluvia1) }\end{array}$ \\
\hline Boron & $0.062 \pm 0.013$ & $9.8 \pm 0.2$ & $1.04 \pm 0.2$ \\
Bromine & $0.015 \pm 0.001$ & $0.35 \pm 0.01$ & $0.23 \pm 0.01$ \\
Calcium & $42 \pm 5$ & $38 \pm 5$ & $180 \pm 15$ \\
Chlorine & $6.5 \pm 0.5$ & $46 \pm 2$ & $35 \pm 2$ \\
Fluoride & $0.35 \pm 0.04$ & $5.2 \pm 0.5$ & $0.75 \pm 0.10$ \\
Iron & $0.71 \pm 0.03$ & $0.28 \pm 0.02$ & $0.15 \pm 0.01$ \\
Lithium & $0.03 \pm 0.01$ & $0.45 \pm 0.04$ & $0.06 \pm 0.01$ \\
Magnesium & $52 \pm 5$ & $52 \pm 5$ & $170 \pm 10$ \\
Sodium & $136 \pm 3$ & $500 \pm 5$ & $280 \pm 3$ \\
Sulfur & $150 \pm 10$ & $150 \pm 10$ & $34 \pm 5$ \\
\hline
\end{tabular}




\section{OIL SAMPLES}

Crude oil samples from the oxy Retort 6 were analyzed for trace elements using neutron activation and $x$-ray fluorescence. Some of the data are shown in Table. 5, and Table 6 includes data from an above-ground process for comparison. The Oxy oil is almost a factor of two lower in its arsenic and selenium contents, but is somewhat higher in the first row transition elements: vanadium, cobalt, nickel, and zinc. Sulfur contents are similar. Compared to crude petroleum, the shale oils are higher in arsenic and molybdenum; lower in nickel, vanadium, and zinc; and similar in iron, cobalt, and selenium.

TABLE 5

Oxy Retort 6 Product Oil -- Preliminary Data (in ppm except as noted)

\begin{tabular}{|c|c|c|c|}
\hline & NAA & $\mathrm{XRF}$ & Other \\
\hline Aluminum & $0.16 \pm 0.06$ & & \\
\hline Anitimony & $0.142 \pm 0.005$ & & \\
\hline Arsenic & $16.1 \pm 0.1$ & $14.2 \pm 0.9$ & \\
\hline Bromine & $0.07 \pm 0.02$ & $<0.47$ & \\
\hline Calcium & $<6$ & & \\
\hline Carbon $(\%)$ & & & 84.74 * \\
\hline Chlorine & $1.3 \pm 0.5$ & & \\
\hline Chromium & $0.4 \pm 0.2$ & & \\
\hline Cobalt & $3.6 \pm 0.18$ & $4.0 \pm 0.8$ & \\
\hline Copper & & $1.0 \pm 0.4$ & \\
\hline Gallium & & $<0.42$ & \\
\hline Hydrogen $\left(\frac{\%}{0}\right)$ & & & $11.82 *$ \\
\hline Iron & $80 \pm 20$ & $35.4 \pm 2.6$ & \\
\hline Lead & & $<1.7$ & \\
\hline Magnesium & $<10$ & & \\
\hline Manganese & $0.021 \pm 0.008$ & & \\
\hline Molybdenum & $2.0 \pm 0.1$ & $1.6 \pm 0.3$ & \\
\hline Nickel & $12 \pm 3$ & $8.7 \pm 0.7$ & \\
\hline Nitrogen & & & $1.5 \pm 0.1^{*}$ \\
\hline Selenium & & $0.54 \pm 0.20$ & \\
\hline Sodium & $11.5 \pm 0.4$ & & \\
\hline Strontium & & $<0.43$ & \\
\hline Sulfur $(\%)$ & $0.72 \pm 0.09$ & $0.80 \pm 0.09$ & $0.75 \pm 0.05$ * \\
\hline Uranium & $<0.01$ & & \\
\hline
\end{tabular}


TABLE 5 (continued)

\begin{tabular}{lccc}
\hline & NAA & XRF & Other \\
\hline Vanàdium & $0.41 \pm 0.02$ & \\
Zinc & $3.0 \pm 1.1$ & $2.1 \pm 0.3$ \\
Zirconium & & $<0.46$ & \\
\hline
\end{tabular}

*Analysis by Schwarzhopf, Inc.

TABLE 6

Comparison of Two Shale Oils and Composite of North American Petroleum (in ppm except as noted)

\begin{tabular}{lcccc}
\hline & Oxy - Retort 6 & $\begin{array}{c}\text { Above-ground Process } \\
\text { (gas combustion) }\end{array}$ & \multicolumn{2}{c}{$\begin{array}{c}\text { Petroleum } \\
\text { Average Range* }\end{array}$} \\
\hline Arsenic & 16 & 27 & 0.2 & $0.05-11$ \\
Carbon (\%) & 84.74 & 84.80 & - & - \\
Cobalt & 3.6 & 1.0 & 1.7 & $0.03-12$ \\
Hydrogen (\%) & 11.82 & 11.26 & - & - \\
Iron & 80 & 60 & 41 & $3-120$ \\
Molybdenum & 2.0 & $<0.3$ & 0.03 & $0.008-0.05$ \\
Nitrogen (\%) & 1.5 & 2.0 & - & - \\
Sodium & 8.7 & 2.7 & 0.75 & $50-350$ \\
Sulfur (\%) & 0.75 & 0.75 & 88 & $0.1-4$ \\
Vanadium & 0.41 & 0.24 & 30 & $4-300$ \\
Zinc & 3.0 & 0.43 & $3-85$ \\
\hline
\end{tabular}

${ }^{*}$ Hitchon, D.R. et $a 1^{3}$

\section{GAS SAMPLES}

Samples of the retort offgas were obtained for mercury and arsenic measurements over a period of five months from the middle to the end of the burn using methods described in Fruchter et al. ${ }^{4}$ The results are shown in Tables 7 and 8 . Temperature of the gas in the offgas line average $78 \pm 3 . \mathrm{C}$. Meicury was detected. during all sampling periods. It showed a steady level of about $13 \mathrm{\mu g} / \mathrm{m}^{3}$ except during April and early May when it temporarily increased to $20-25 \mu \mathrm{g} / \mathrm{m}^{3}$. The arsenic measurements indicate that very little arsenic was being emitted from Retort 6 during March since most of the measurements reported in Table 8 are near blank levels. Speciation measurements showed that what little arsenic there was, was present as arsenic trioxide. Some comparison data from an above-ground process is presented. 


\section{TABLE 7}

Mercury in Offgas from Oxy Retort 6

Preliminary Data

(in $\mu \mathrm{g} \mathrm{Hg} / \mathrm{m}^{3}$ gas)

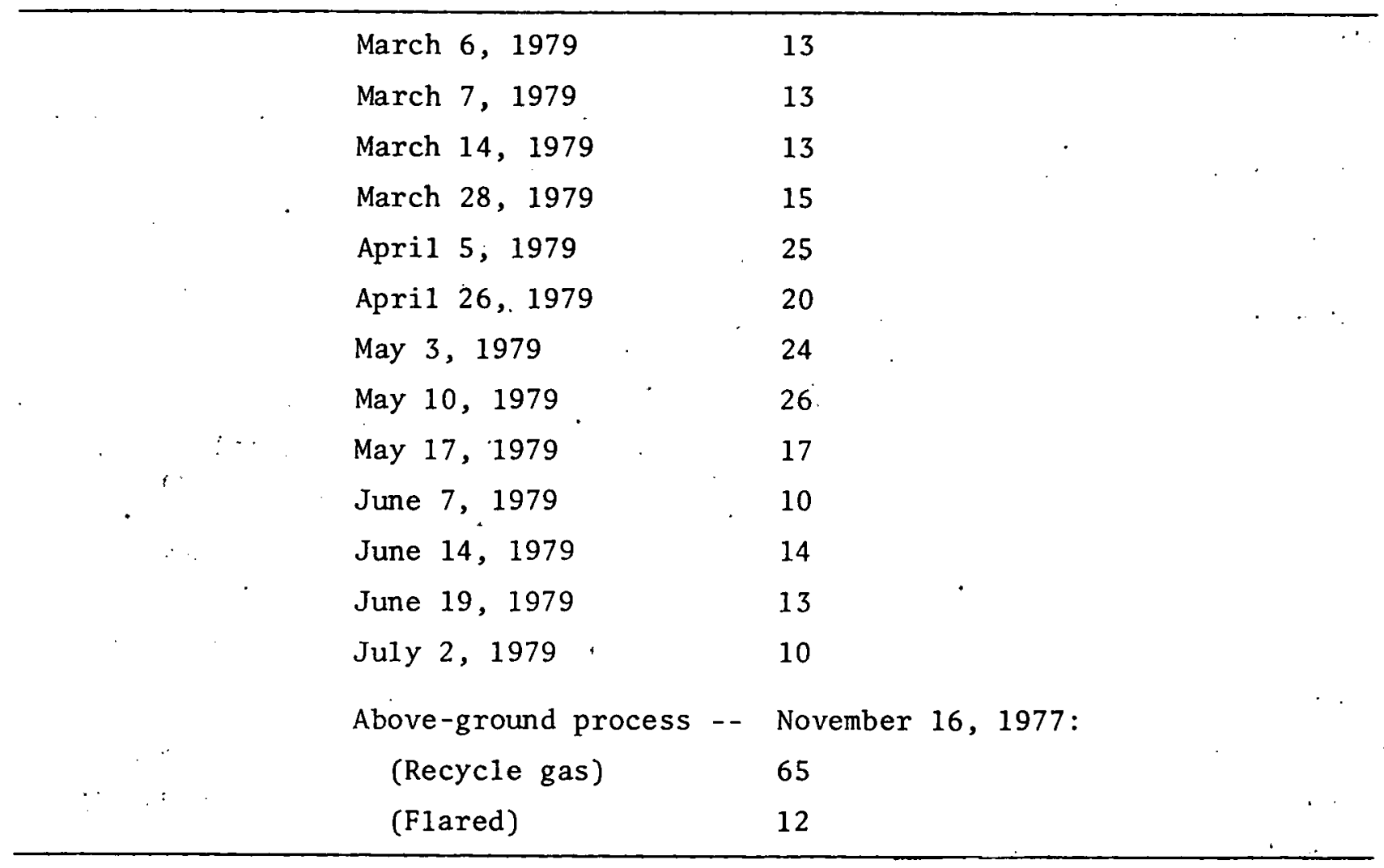

TABLE 8

Arsenic Speciation in Offgas from Oxy Retort 6 Preliminary Data

(in $\mu \mathrm{g} / \mathrm{m}^{3}$ )

\begin{tabular}{|c|c|c|c|}
\hline & $\mathrm{As}_{4}{ }_{6}$ & $\mathrm{AsH}_{3}$ & Organic Forms \\
\hline March 6, 1979 & $1.8 \pm 0.8$ & $3.5 \pm 1.0 *$ & $<0.4$ \\
\hline March 7, 1979 & $<0.8$ & $1.8 \pm 0.8 *$ & $<0.9$ \\
\hline March 28, 1979 & $<0.8$ & $0.85 \pm 0.35 *$ & $<0.9$ \\
\hline
\end{tabular}

Above-ground process -- November 16, 1977 :

(Flared)

12

0.3

$<0.8$

*Near blanks' -- not significant 


\section{SPENT SHALE CORE SAMPLES}

Eighteen samples were obtained from a core taken in spent shale from Oxy's Retort 3E. These samples were.given to the Task Force by Occidental Oil Shale, Inc. Quantitative elemental information was obtained using colorimetric, $x$-ray fluorescence, and neutron activation analysis procedures. Results are shown in Tables 9 and 10 . Mineralogical analyses utilizing $x$-ray diffraction are shown in Table 11 .

The analysis of boron and fluoride in the spent shale can be reported with some degree of certainty (Table 9). The concentrations show variability with core depth, but there is, in general, an increase with depth. It remains to be seen whether this is due to a difference in thermal history or if it reflects the nature of the geological materials prior to the burn. This underlines the importance of having "before" and "after" burn cores for comparison.

Table 10 gives quantitative elemental analysis for the spent shale core samples. The Oxy samples show considerably higher variability than samples obtained previously. from an above-ground process. Several samples in particular show unusual compositions. Sample $4(460-463 \mathrm{ft}$ ) is unusually high in sodium (3.3\% compared to an average of around $1.2 \%)$. Sample $1(442-445 \mathrm{ft})$ is high in aluminum, calcium, magnesium, and phosphorus and very low in arsenic. Samples 17 and 18 (500-515 ft) are quite low in calcium, potassium, and magnesium and high in silicon. Presumably these variations can be traced to mineralogy. Again, it is unfortunate that no samples of the raw shale were available for comparison. In general, compared to the above-ground shales, the oxy shales were lower in arsenic, molybdenum, and sodium and higher in calcium.

TABLE 9

Boron and Fluoride in Oxy Retort 3E Spent Shale*

\begin{tabular}{rrrr}
\hline $\begin{array}{c}\text { Sample } \\
\#\end{array}$ & $\begin{array}{c}\text { Depth } \\
\mathrm{ft} .\end{array}$ & $\begin{array}{c}\mathrm{F} \\
\mathrm{gg} / \mathrm{g} \\
\pm 10 \%\end{array}$ & $\begin{array}{c}\mathrm{B} \\
\mu \mathrm{g} / \mathrm{g} \\
\pm 10 \%\end{array}$ \\
\hline 1 & $442-445$ & 470 & 210 \\
3 & $457-460$ & 530 & 140 \\
4 & $460-463$ & 680 & 110 \\
14 & $483-485$ & 1200 & 275 \\
15 & $483.5-485.5$ & 1100 & 210 \\
17 & $500-506$ & 2600 & 470 \\
18 & $506-515$ & 2300 & 550 \\
\hline
\end{tabular}

*F: Gas diffusion-colorimetric

B: Colorimetric (Azomethine-H) 
TABLE 10
Analyses of Core Samples From Oxy Retort 3E
Preliminary Data*
(in ppm except as noted)

\begin{tabular}{|c|c|c|c|c|c|c|c|c|c|}
\hline $\begin{array}{c}3 E \\
\text { Sample }\end{array}$ & No. & $\begin{array}{c}\text { Mean } \\
\text { Sample } \\
\text { Depth }(f t)\end{array}$ & $\begin{array}{r}A 1(\%) \\
(N) \%\end{array}$ & $\begin{array}{l}\text { As } \\
(\mathrm{N})\end{array}$ & $\begin{array}{c}B \\
(P) \pi\end{array}$ & $\begin{array}{r}\mathrm{Ba} \\
(\mathrm{N})\end{array}$ & $\begin{array}{l}\mathrm{Ca}(\%) \\
(\mathrm{X}) * *\end{array}$ & $\begin{array}{l}\mathrm{Cs} \\
(\mathrm{N})\end{array}$ & $\begin{array}{l}\mathrm{Fe} \\
(\mathrm{N})\end{array}$ \\
\hline & & & $\pm 2 \%$ & $\pm 7 \%$ & & $\pm 10 \%$ & $\pm 7^{\circ}$ & $\pm 10 \%$ & $\pm 3 \%$ \\
\hline 1 & & 443.5 & 4.5 & 6.2 & 228 & 800 & 28 & 3.5 & 2.51 \\
\hline 2 & & 455.5 & 2.5 & 21 & 98 & 550 & 23 & 2.2 & 1.29 \\
\hline 3 & & 459.5 & 3.3 & 26 & 154 & 670 & 18 & 3.0 & 1.72 \\
\hline 4 & & 461.5 & 5.6 & 25 & 154 & 720 & 10 & 5.3 & 1.74 \\
\hline 5 & & 464.5 & 4.3 & 21 & 184 & 750 & 18 & 3.6 & 2.42 \\
\hline 6 & & 468.5 & 4.3 & 19 & 330 & 520 & 17 & 4.6 & 2.51 \\
\hline .7 & & 469.8 & 4.2 & 23 & 228 & 740 & 20 & 6.4 & 2.06 \\
\hline 8 & $\cdot$ & 472.5 & 4.2 & 23 & 235 & 530 & 18 & 5.2 & 2.24 \\
\hline 9 & & 476 & 4.2 & 12 & 145 & 730 & 21 & 4.8 & 2.18 \\
\hline 10 & & 476.5 & 4.4 & 17 & 195 & 67 & 22 & 6.2 & 2.14 \\
\hline 11 & & 478.5 & 4.2 & 29 & 260 & 710 & 24 & 4.6 & 2.49 \\
\hline 12 & & 481 & 4.5 & 24 & 205 & 700 & 23 & 4.7 & 2.54 \\
\hline 13 & & 483.5 & 5.3 & 17 & 265 & 580 & 19 & 6.2 & 3.06 \\
\hline 14 & & 484 & 5.6 & 15 & 310 & 640 & 20 & 6.0 & 3.02 \\
\hline 15 & & 484.5 & 4.9 & 76 & 215 & 700 & 24 & 5.8 & 2.76 \\
\hline 16 & & 493 & 4.8 & 29 & 215 & 760 & 22 & 8.8 & 2.64 \\
\hline 17 & & 503 & 6.7 & 40 & 550 & 610 & 12 & 4.4 & 3.16 \\
\hline 18 & & 510.5 & 7.1 & 39 & 640 & 500 & 8.2 & 5.3 & 3.33 \\
\hline
\end{tabular}

- continued- 
TABLE 10

(continued)

\begin{tabular}{|c|c|c|c|c|c|c|c|c|}
\hline $\begin{array}{c}3 E \\
\text { Sample No. }\end{array}$ & $\begin{array}{c}\text { Mean } \\
\text { Sample } \\
\text { Depth (ft) }\end{array}$ & $\begin{array}{l}\mathrm{Hg}(\mathrm{ppb}) \\
(\mathrm{FAA})++\end{array}$ & $\begin{array}{r}K(\%) \\
(N+X)\end{array}$ & $\begin{array}{l}M g(\%) \\
(N+A)\end{array}$ & $\begin{array}{l}\text { Mo } \\
(X)\end{array}$ & $\begin{array}{l}\mathrm{Na}(\%) \\
(\mathrm{N})\end{array}$ & $\begin{array}{l}\mathrm{Ni} \\
(\mathrm{X})\end{array}$ & $\begin{array}{l}\mathrm{Si}(\%) \\
(\mathrm{X})\end{array}$ \\
\hline ' & & $\pm 15 \%$ & $\pm 10 \%$ & $\pm 10 \%$ & $\pm 10 \%$ & $\pm 2 \%$ & $\pm 10 \%$ & $\pm 10 \%$ \\
\hline 1 & 443.5 & 34 & 2.7 & 8.2 & 4.8 & 1.19 & 17 & 20 \\
\hline 2 & 455.5 & 38 & 0.92 & 4.9 & 4.0 & 1.28 & 16 & 13 \\
\hline 3 & 459.5 & 39 & 1.2 & 5.4 & 5.2 & 1.12 & 16 & 18 \\
\hline 4 & 461.5 & 51 & 0.81 & 2.5 & 9.8 & 3.31 & 18 & 27 \\
\hline 5 & 464.5 & 20 & 2.6 & 5.9 & 2.9 & 0.53 & 26 & 16 \\
\hline 6 & 468.5 & 34 & 2.8 & 6.6 & 4.1 & 0.79 & 23 & 17 \\
\hline 7 & 469.8 & 43 & 2.7 & 6.3 & 4.5 & 1.31 & 26 & 19 \\
\hline 8 & 472.5 & 38 & $=3.1$ & 6.9 & 4.5 & 0.96 & 27 & 19 \\
\hline 9 & 476 & 24 & 2.9 & 6.4 & 5.3 & 1.22 & 35 & 17 \\
\hline 10 & 476.5 & 42 & 2.5 & 5.7 & 5.9 & 1.43 & 41 & 17 \\
\hline 11 & 478.5 & 67 & 2.8 & 6.1 & 7.9 & 1.05 & 30 & 16 \\
\hline 12 & 481 & 38 & 3.3 & 5.9 & 8.2 & 1.01 & 36 & 16 \\
\hline 13 & 483.5 & 43 & 4.0 & 5.9 & 15 & 0.98 & 32 & 20 \\
\hline 14 & 484 & 77 & 3.6 & 5.4 & 23 & 1.15 & 34 & 21 \\
\hline 15 & 484.5 & 44 & 2.5 & 7.3 & 15 & 1.43 & 34 & 18 \\
\hline 16 & 493 & 44 & 2.7 & 6.1 & 23 & 1.50 & 30 & 21 \\
\hline 17 & 503 & 24 & 6.3 & 3.6 & 19 & 0.87 & 36 & 24 \\
\hline 18 & 510.5 & 35 & $6: 4$ & 4.9 & 18 & 1.14 & 36 & 25 \\
\hline
\end{tabular}


TABLE 10

(continued)

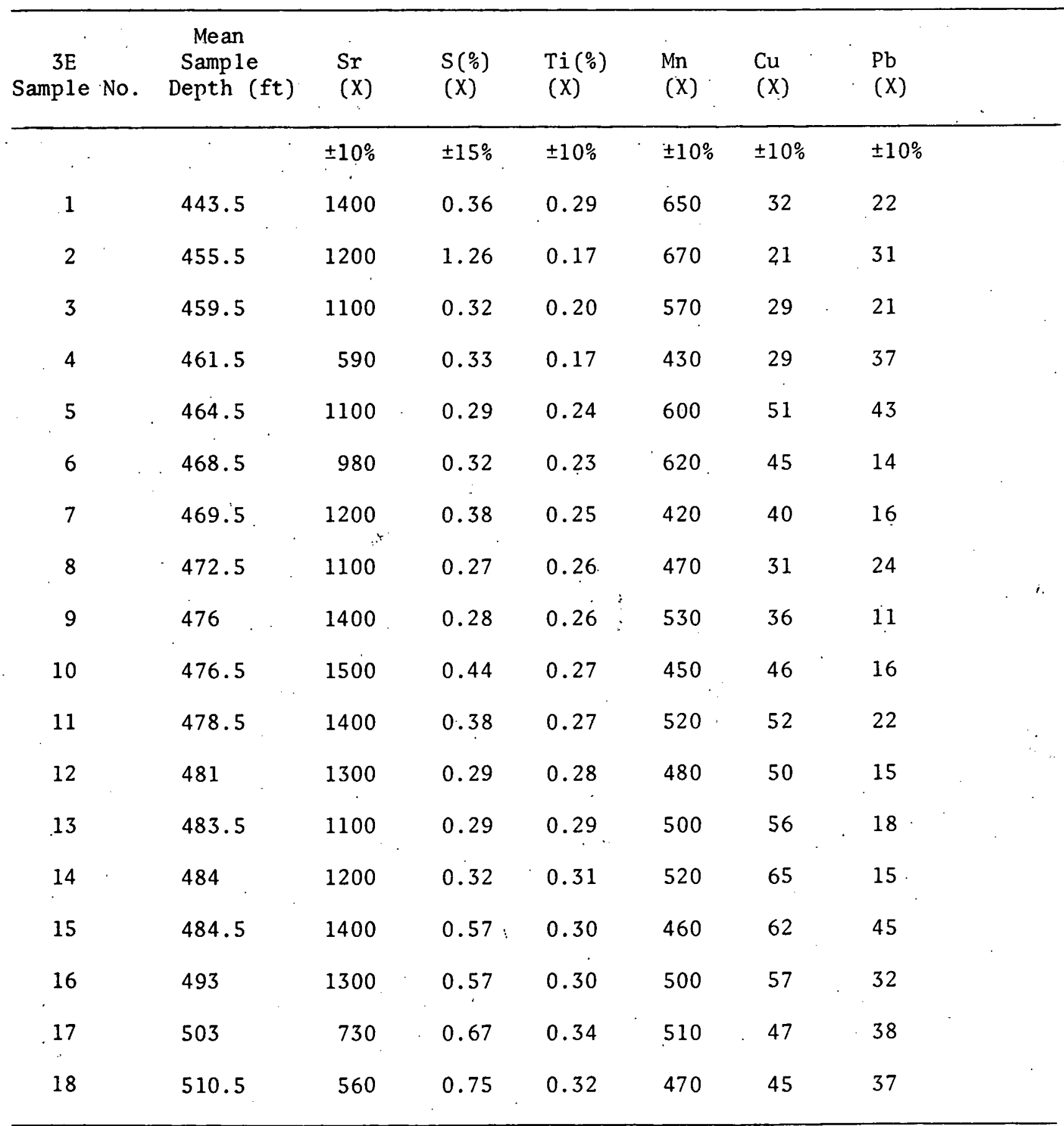

* = Samples were obtained from 5 foot intervals and represent composite of said intervals. The mean sampled depth is the midpoint of said 5 foot interval.

$+\mathrm{N}=$ Neutron Activation Analysis

IP $=$ DC Plasma Emission Spectroscopy

$* * X=X$-ray Flourescence

$\uparrow+F A A=F l$ ameless atomic absorption 
TABLE 11

Mineralogical Analyses for Selected Samples of Oxy Retort 3E Spent Shale Core

\begin{tabular}{cll}
\hline & $\# 5$ & $\# 16$ \\
\hline Mean depth (ft) & 464.5 & 493 \\
Major mineral (s) & Calcite & Akermanite \\
Minor mineral (s) & Diopside & Diopside \\
& A-quartz & \\
& Aragonite & \\
Trace mineral (s) & Akermanite & Kalsilite \\
& & 2 Unidentified phases \\
\hline
\end{tabular}

The mineralogical results of the spent shale cores are presented in Table 11. Sample 5 (top portion of the retort) contains much calcite $\left(\mathrm{CaCO}_{3}\right)$ with some diopside $\left(\mathrm{CaMgSi}_{2} \mathrm{O}_{6}\right)$, quartz $\left(\mathrm{SiO}_{2}\right)$, and $\mathrm{ka1silite}\left(\mathrm{KAlSiO}_{4}\right)$, and a small amount of akermanite $\left(\mathrm{Ca}_{2} \mathrm{MgSi}_{2} \mathrm{O}_{7}\right)$. Samples 16 contains much akermanite, with some diopside and kalsilite, but no calcite. This would imply that the lower portions of the retort have seen a higher temperature than the top, or were at a highr:temperature for a longer period of time. This is consistent with other information presented to the Task Force concerning Retort 3 .

Calcium occurs alone ( $\mathrm{CaO}$ or $\left.\mathrm{CaCO}_{3}\right)$ and with potassium, magnesium, iron, aluminum, and silicon. When iron is present, the calcium and silicon are low. Occasional quartz and potassium aluminosilicates are also observed. Fluorine is postulated to occur as fluorapatite or as fluoro aluminosilicates. Scanning electron microscopy studies have shown that the silicate and carbonate areas are quite separate in the Mahogany Zone and that sulfides, especially pyrite, occur with kerogen in the silicate regions (LASL report).

\section{LEACHATES FROM SPENT SHALE}

In several cases, leachate analyses have more environmental significance than the elemental analyses of the spent shale. The leachates also present analytical problems similar to the problems encountered in process water analyses. The work on leaching is discussed in Chapter 3.

It has been learned that during recovery of the Retort 3E samples by drilling they were contaminated by a number of materials used during the drilling process. These included Baroid-Quik foam and Poly D-1000 polymer, both of which were used as lubricants and to support the encased portions of the drill hole (without these additives the drilling bit could have easily burned up). In addition, some of the samples 
were contaminated by the pipe dope used to thread the drill string joints together. Therefore, interpretation of the leaching results must take into account the composition of these various compounds. Analyses for these compounds are shown in Table 12 .

\section{SHALE OIL PARAFFINS}

The n-alkane distribution in four shale oils and two petroleums has been determined. A silica gel column with $\mathrm{n}$-hexane as the eluant was used to separate aliphatic hydrocarbons from more polar materials. The hydrocarbons were then analyzed by glass capillary gas chromatography. Normal-alkanes predominate in the chromatograms of these samples; however, in one petroleum (Gato Ridge), n-alkanes were overwhelmed (by other constituents, presumably cyclic or branched alkanes). Normal-alkanes are minor or absent in the samples studied with the exception of Paraho and; to a lesser extent, Livermore. The n-alkane distribution from Paraho, Occidental, Geokinetics, and Livermore shale oils; Occidental shale oil; light oil (collected from retort offgas treatment pilot plant); and Prudhoe Bay and Wilmington crude oils is shown in Figure 2. Most of the samples also have decreasing, amounts of $n$-alkanes up to at least $\mathrm{C}_{36}$. It can be readily seen that Paraho, Geokinetics, Occidental product and Occidental sludge are similar with respect to n-alkanes; Livermore is also similar to the other shale oils, except for the large peak at $\mathrm{nC}_{14}$. The petroleums differ from the shale oils and from each other; the odd carbon predominance seen in the shale oils is less pronounced than in the petroleums studied.

\section{FURTHER ANALYTICAL REQUIREMENTS}

Although the characterization results are preliminary in nature, they do point out the need for better sampling and analytical methodology in some areas. It is essential to have the pre-burn and post-burn history in order to evaluate mineralogical behavior. A method to test the temperatures to which samples have been subjected is required. Statistical or mechanistic correlations are also required among core compositions, retorting temperature, and leaching behavior. It is possible that this information will have to be obtained by combining laboratory experiments where the retorting conditions can be highly controlled with information obtained from the field. Data on material around the retort are required to determine whether leachates will be chemically altered by the surrounding materials. Anion analyses on shale related matrices continue to present significant discrepancies and therefore are not discussed in this report, nonetheless, these are important data that are being investigated. Verification of results and further sample analyses are underway and will be reported later.

\section{SUMMARY}

While theiresults to date require additional verification and data from samples taken at various times in order to tell whether they are representative of the process, there are important conclusions that have implications for future research 
TABLE 12

Analysis of Drilling Agents Used in the Recovery of Occidental Oil Shale Spent Shale R3E1

(in ppm except as noted)

\begin{tabular}{|c|c|c|c|c|}
\hline & Baroid Quik Foam & Poly & D - 1000 Polymer & Pipe Dope \\
\hline Aluminum & $<1$ & & $65 \pm 3$ & - \\
\hline Arsenic & $<0.8$ & & $<0.3$ & $18 \pm 5$ \\
\hline Boron & $0.5 \pm 0.1$ & & $9 \pm 1$ & - \\
\hline Bromine & $2 \pm 0.5$ & & $<0.3$ & $<2$ \\
\hline Calcium $(\%)$ & $<0.03$ & & $<0.03$ & $0.45 \pm 0.2$ \\
\hline Chlorine $(\%)$ & $0.007 \pm 0.01$ & & $4.2 \pm 0.3$ & $<0.04$ \\
\hline Chromium & $<4$ & & $<5$ & $37 \pm 11$ \\
\hline Cobalt & $<1$ & & $<1$ & $<26$ \\
\hline Copper & $3.6 \pm 0.4$ & & $3.2 \pm 0.4$ & $<19$ \\
\hline Iron & $20 \pm 2$ & & $125 \pm 7$ & $167 \pm 12$ \\
\hline Lead & $<1$ & & $<1$ & $330 \pm 30$ \\
\hline Magnesium & $0.3 \pm 0.1$ & & $5 \pm 1$ & - \\
\hline Manganese & $<2$ & & $<2$ & $<17$ \\
\hline Mercury & $<1$ & & $<1$ & - \\
\hline Nicke1 & $<0.6$ & & $<0.6$ & $24 \pm 5$ \\
\hline Potassium $(\%)$ & $<0.06$ & & $<0.06$ & $<0.02$ \\
\hline Rubidium & $<0.4$ & & $<0.4$ & $<2$ \\
\hline Selenium & $<0.3$ & & $<0.3$ & $<2$ \\
\hline Silicon & $<5$ & & $200 \pm 20$ & $<0.6 \%$ \\
\hline Sodium $(\%)$ & $0.041 \pm 0.003$ & & $3.0 \pm 0.3$ & - \\
\hline Strontium & $<4$ & & $<4$ & $<13$ \\
\hline Sulfur $(\%)$ & $9.4 \pm 0.7$ & & $<0.9$ & $0.12 \pm 0.04$ \\
\hline Titanium & $<35$ & & $<35$ & $<35$ \\
\hline Vanadium & $<9$ & & $<9$ & $<7$ \\
\hline Zinc & $10.8 \pm 0.6$ & & $7.8 \pm 0.6$ & $260,000 \pm 20,000$ \\
\hline $\begin{array}{l}\text { Total organic } \\
\text { carbon }\end{array}$ & 292,000 & & 242,000 & - \\
\hline
\end{tabular}


OXY PRODUCT

GEOKINETICS

PRUDHOE BAY
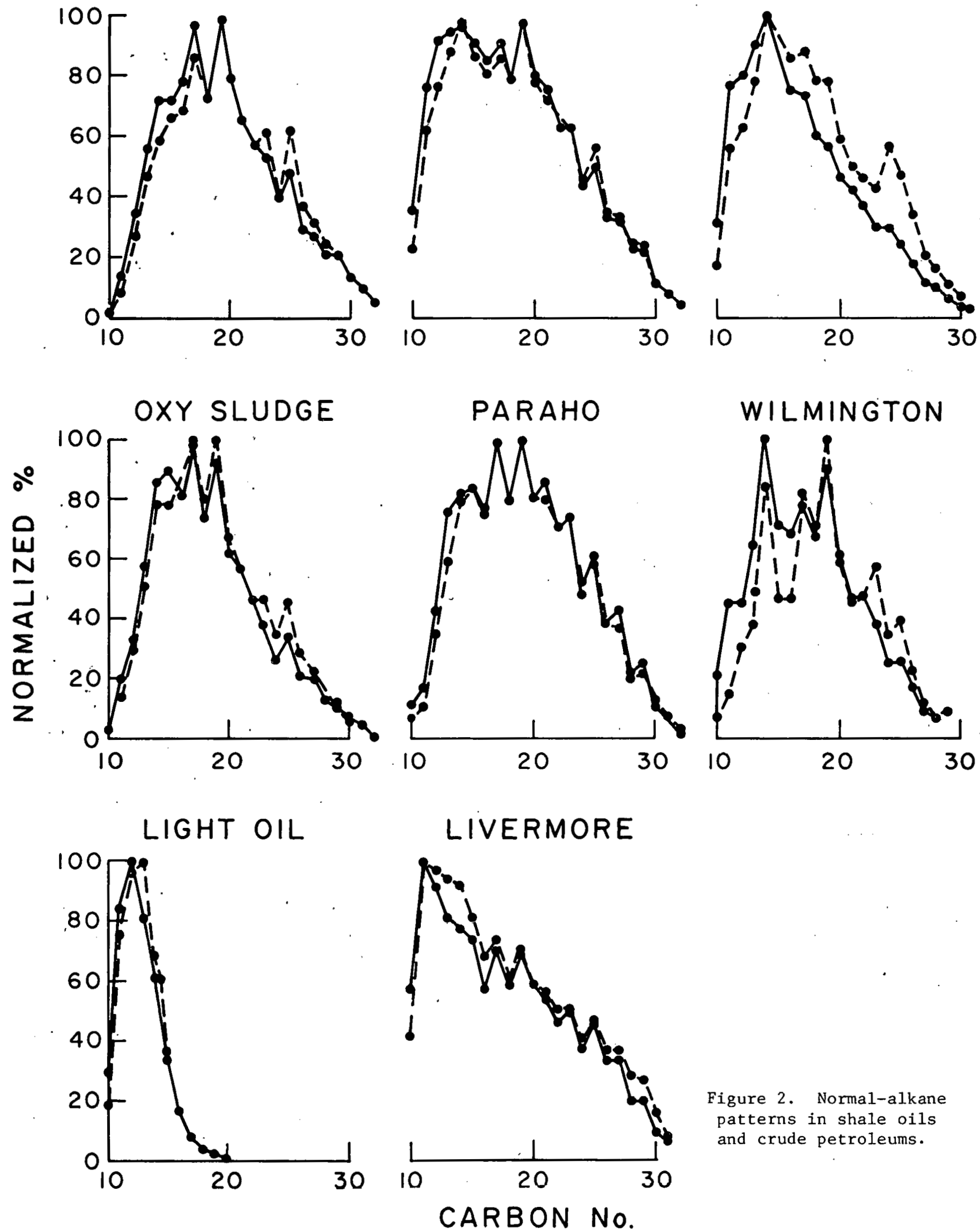

Figure 2. Norma1-alkane patterns in shale oils and crude petroleums.

Figure 2. Normal-alkane patterns in shale oils and crude petroleums. 
directions. Numerous samples of various materials were collected from Retort 6. In addition, core samples from Retort No. 3E were provided by Occidental Oil Shale, Inc.

Preliminary analyses of the oils from Retort 6 indicate differences in the concentrations of various constituents than other shale oils and crude petroleums. In particular, Oxy shale oil is lower in arsenic and selenium and higher in vanadium, cobalt, nickel, and zinc than other shale oils that have been analyzed. In general, all shale oils analyzed to date (both surface produced and MIS) are higher in arsenic, selenium, cobalt, and nitrogen, and lower in vanadium and nickel compared to crude petroleums. The Retort 6 product waters were found to be compositionally different from product waters produced by above-ground processes. Mercury has been detected in all gas samples analyzed to date, however, very little arsenic in any form was detected. The core samples from Retort 3E show considerably greater variation than found in shale samples from process and simulated in situ retorts. This is not surprising because less mixing occurs than in surface retorts and there is more control of process parameters in laboratory retorts than in the field. Boron, fluoride, arsenic, sulfur, and molybdenum generally increase with depth. Other elements fluctuate more or less randomly with depth. While core samples of unretorted shales have not been analyzed, it is likely that this behavior as a function of depth relates to the original mineralogy. All core samples showed residual mercury concentrations as opposed to spent shales obtained from simulated in situ retorts. Oxy spent shales are generally higher in boron and calcium and lower in sodium and molybdenum than other spent shales studied to date. However, the Task Force discovered that drilling fluids were used in the recovery of the core and thus some contamination occurred. Samples of the drilling fluids were obtained and analyzed for a number of constituents. One fluid was found to be very high in zinc and therefore may have affected the analyses. Recently Occidental Oil Shale, Inc., in a program jointly funded by Oxy and the Department of Energy, obtained two more cores, R3E2 and R3E3. Personnel from the Task Force were present when these cores were obtained and no drilling fluids other than water were used. These cores will provide the Task. Force with significantly more material than previously obtained.

\section{REFERENCES}

${ }^{1}$ Tsunoda, K., K. Fujiwara, and K. Fuwa. "Subnanogram Fluorine Determination by Aluminum Mono Fluoride Molecular Absorption," Anal. Chem., 49:2035-2039 (1977).

${ }^{2}$ Meglen, B. and A. Krikos. "The Determination of Fluorine in Oil Shale Related Matrics Using Graphite Furnace Molecular Absorption," In Proceedings of Oil Shale Symposium: Sampling; Aralysis; and Quality Assurance. March 1979. EPA/DRI. (in press).

${ }^{3}$ Hitchon, D.R., R.H. Filby, and K.R. Shah. In Roles of Trace Metalsitin Petroleum. T.F. Yen, ed. Ann Arbor Science Pub., Ann Arbor, MI. 1975.

${ }^{4}$ Fruchter, J. et al. Source Characterization Studies at the Paraho Semiworks Oil Shale Retort. PNL 2945/U091. Pacific Northwest Labs, Richland, WA. 1979 . 
Chapter 3

\section{LEACHING STUDIES OF OCCIDENTAL RETORT 3E SPENT SHALE SAMPLES}

\section{INTRODUCTION}

This progress report describes the results of investigations representing the first phase in implementing the Water Quality section (B.6.3.2) and the Environmental Control Technology section (B.6.4) from Appendix B of the "ASEV Modified In Situ Task Force Research Plan for Occidental Oil Shale, Incorporated" activities at Logan Wash, Colorado. In addition, these activities constitute part of Task A18 of the DOE Oil Shale R,D and D Program Management Plan. This effort was conducted by research teams at the University of Colorado at Boulder (CU), Los Alamos Scientific Laboratory (LASL), and Battelle-Pacific Northwest Laboratories (PNL). The report establishes program objectives, describes materials and methods, and lists conclusions for each team of investigators; and finally. lists general conclusions for the combined research effort.

Retorted shale samples from a core of Retort 3E were provided by Occidental Oil Shale, Inc. (Oxy) for this initial study. Retort $3 \mathrm{E}$ was subjected to modified in situ (MIS) retorting, exhausted, cooled, and sampled by core drilling. Eighteen samples were received by the Task Force representing composite samples from 442 to 515 feet (Table 1). Samples were ground to -100 mesh in agate mortars prior to distributing to the participating laboratories. Due to the limited time and sample size, the investigations must be considered preliminary as a basis for more extensive subsequent investigations in the laboratory as larger samples become available and in the field. In addition, the small sample size also necessitated the development of new analytical methods and experimental procedures by. some of the laboratories.

After completion of the leaching studies described in the current report it was learned that several components were employed during drilling of the core to facilitate retrieval of unconsolidated materials. In addition to pipe dope, normally employed, a foam and surfactant were added at several drilling intervals. Calculations based on the composition (Table 12, Chapter 2) and the assumed maximum capacity of the shale to retain the materials indicated that their use would significantly affect the concentration of at least carbon and zinc in the leachates. The precise impact of the use of these materials on leaching results must await comparison with subsequent cores which were retrieved without employing specialized chemicals on request by the Task Force.

\section{OBJECTIVES}

The general objective of this research effort within the Task Force is to study and characterize the leachates from Retort $3 \mathrm{E}$ shale in order to understand the mechanisms and consequences of release and aqueous transport of elements from retorted shales. However, the objectives of the individual laboratories did vary which resulted in different analytical methods being used. For example, CU and PNL used column leaching techniques to obtain kinetic data whereas LASL 
TABLE 1

Designation and Distribution for Occidental Retort 3E Shale Core Samples

\begin{tabular}{|c|c|c|c|c|c|}
\hline $\begin{array}{l}\text { Core Sample } \\
\text { Number }\end{array}$ & Depth (ft.) & $\begin{array}{c}\text { Total Sample } \\
\text { Weight }(\mathrm{g})\end{array}$ & $\begin{array}{l}\text { CU Sample } \\
\text { (g) }\end{array}$ & $\begin{array}{l}\text { LASL Sample } \\
(\mathrm{g})\end{array}$ & $\begin{array}{c}\text { PNL sample } \\
\text { (g) }\end{array}$ \\
\hline 1 & $442-445$ & 54.2 & 25 & 10 & 10 \\
\hline 2 & $454-457$ & 54.2 & & 20 & 20 \\
\hline 3 & $457-460$ & 51.8 & 25 & 10 & 10 \\
\hline 4 & $460-463$ & 57.3 & 25 & 10 & 10 \\
\hline 5 & $463-466$ & 52.7 & & 10 & 20 \\
\hline 6 & $468-469$ & 58.0 & & 20 & 20 \\
\hline 7 & $469-470.5$ & 54.3 & & 20 & 20 \\
\hline 8. & $470-475$ & 55.4 & & 20 & 20 \\
\hline 9 & $475-477$ & 55.8 & . & 20 & 20 \\
\hline 10 & $475.5-477.5$ & 52.6 & & 20 & 20 \\
\hline 11 & $477-480$ & 55.3 & . & 20 & 20 \\
\hline 12 & $480.5-481.5$ & 50.3 & & 20 & 20 \\
\hline 13 & $481.5-485.5$ & 52.2 & & 20 & 10 \\
\hline 14 & $483-485$ & 50.6 & 25 & 10 & 10 \\
\hline 15 & $483.5-485.5$ & 49.8 & 20 & 10 & 10 \\
\hline 16 & $485.5-500.5$ & 52.8 & & 20 & 20 \\
\hline 17 & $500-506$ & 50.2 & 20 & & 10 \\
\hline 18 & $506-515$ & 54.5 & 25 & & 10 \\
\hline
\end{tabular}


used a static shaker method. The different techniques were thus used by the Task Force to maximize information obtained from the limited sample sizes. The specific objectives of the individual research laboratories are listed below.

CU Objectives:

- To determine if high MIS retorting temperatures produce a solid product which is less soluble in water than surface retorted shale.

- To compare the chemistry of Retort 3E leachates from small laboratory columns to leachates from similar columns of TOSCO and aboveground retorted shales.

LASL Objectives:

- To identify areas where environmental controls might be applied to water contamination arising from leaching of MIS retorted shales.

PNL Objectives:

- To investigate the leachability and mutagenicity of inorganic and organic residuals of retorted MIS shale as influenced by equilibration under aerobic and anaerobic conditions, volume of percolate, and time.

- To identify the movement and effects of leachates to surface and ground waters over a wide.range of process and environmental conditions. .

It has been suggested that the retorting of oil shale at high temperatures for long periods (as might be experienced under MIS conditions) would decrease the inorganic and organic residuals subject to aqueous leaching due to the formation of refractory minerals. Both the $\mathrm{CU}$ and $\mathrm{PNL}$ sutdies were designed to evaluate this process and the accompanying claim of insolubility.

\section{UNIVERSITY OF COLORADO}

\section{Materials and Methods}

Four small columns of Retort $3 E$ retorted shale were prepared; Column 1 consisted of Core Sample No. 1, Column 2 was a composite of Samples 3 and 4, Column 3 was a composite of Samples 14 and 15, and Column 4 was a composite of Samples 17 and 18. These materials were chosen for study on the basis of the apparent degree of retorting, as indicated by the mineralogy summarized in the transmittal from Oxy dated January 19, 1979 (see Fig. 1). Composite samples were used in order to obtain adequate leachate for reliable analysis. The physical parameters of each column are summarized in Table 2 .

The retorted shale was packed dry in polyethylene tubes which measured approximately $1.5 \times 15 \mathrm{~cm}$. The shale was saturated with distilled water by 


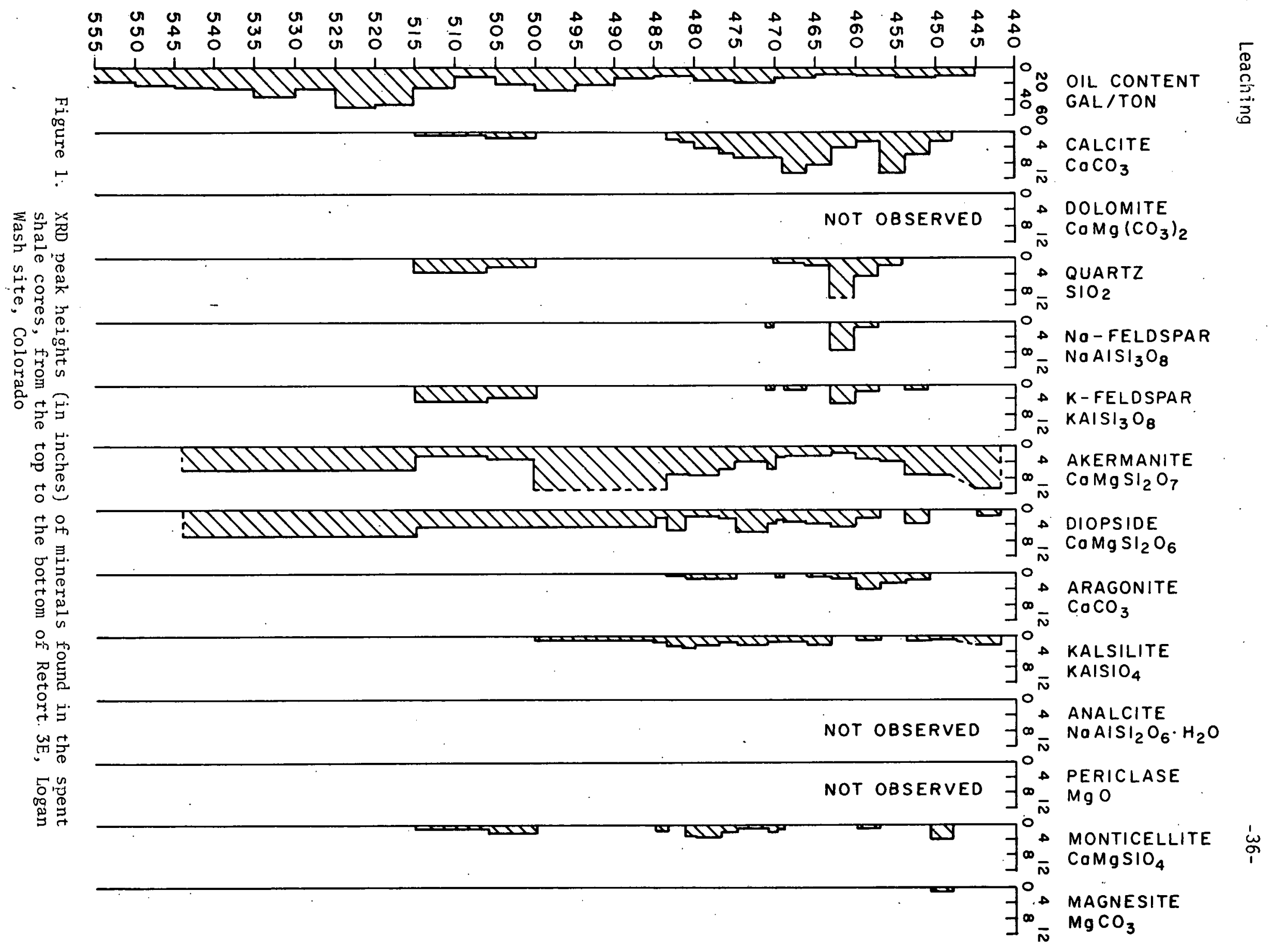


TABLE 2

Conditions and Parameters for Column Leaching Studies

\begin{tabular}{lcccc}
\hline & \multicolumn{5}{c}{ Occidental } & Core Sample Number \\
\cline { 2 - 5 } & \multicolumn{1}{c}{} & \multicolumn{1}{c}{$3+4$} & $14+15$ & $17+18$ \\
\hline Weight of sample $(\mathrm{g})$ & 23.8 & 36.4 & 38.2 & 39.2 \\
Bulk density $(\mathrm{g} / \mathrm{cc})$ & 1.7 & 1.2 & 1.2 & 1.3 \\
Pore volume $(\mathrm{m} \ell)$ & 4.8 & 13.8 & 12.9 & 14.9 \\
Porosity $(\%)$ & 34 & 44 & 42 & 48 \\
Hydraulic conductivity $(\mathrm{cm} / \mathrm{sec})$ & $2.9 \times 10^{-4}$ & $7.3 \times 10^{-5}$ & $9.3 \times 10^{-5}$ & $3.1 \times 10^{-5}$ \\
\hline
\end{tabular}

gradual infiltration from the bottom and then sealed for 31 days. The entire set of experiments was open to the air. After 31 days the columns were leached with distilled water, with the water passing in the same direction as that used for initial saturation. Up to five column volumes of leachate were collected from each column. All experiments were conducted at room temperature.

The leachates wexe analyzed for $\mathrm{pH}$, conductivity, thiosulfate, sulfate, calcium, fluoride, boron, molybdenum, arsenic, and selenium. The analytical results are summarized in Tables 3 and 4.

In addition to the work on aqueous leachates, some characterization of the solids themselves was performed. Of particular interest is the geochemistry of boron and fluoride, and the concentrations of these two elements in the retorted shale samples are summarized in Table 5 .

The University of Colorado is interested in the surface area and surface charge of the solids as one component of a computer modeliing study dealing with the release and movement of dissolved constituents from oil shale. Thus, the specific surface area of column 2. (composite of Samples 3 and 4) was measured, and the results are shown in Table 6. Similarly, in order to model the movement of dissolved contaminants through the shale, the net negative charge on the surfaces of the solids must be known. Table 7 summarizes the measurement of surface charge as a function of $\mathrm{pH}$.

In the aqueous leachates, the $\mathrm{pH}$ was measured with a glass electrode, using two buffers for calibration. Conductivity was measured with a glass-platinum dip cell. Thiosulfate and sulfate were determined by colorimetric titration, calcium by flame atomic absorption, and boron and fluoride by a wet fluorescence technique. Molybdenum was determined colörimetrically, and arsenic and selenium were determined by $x$-ray fluorescence on evaporated residues. The mineralogy of the solids was determined by $x$-ray diffraction.

For the solid retorted shale samples, boron and fluoride were determined by $a$ wet fluorescence procedure after acid digestion of the samples. Surface area was measured by the B.E.T. gas saturation method using nitrogen gas after overnight 
TABLE 3

Variation of Conductivity and $\mathrm{pH}$ with Number of Pore

Volumes of Leachate from Each Column

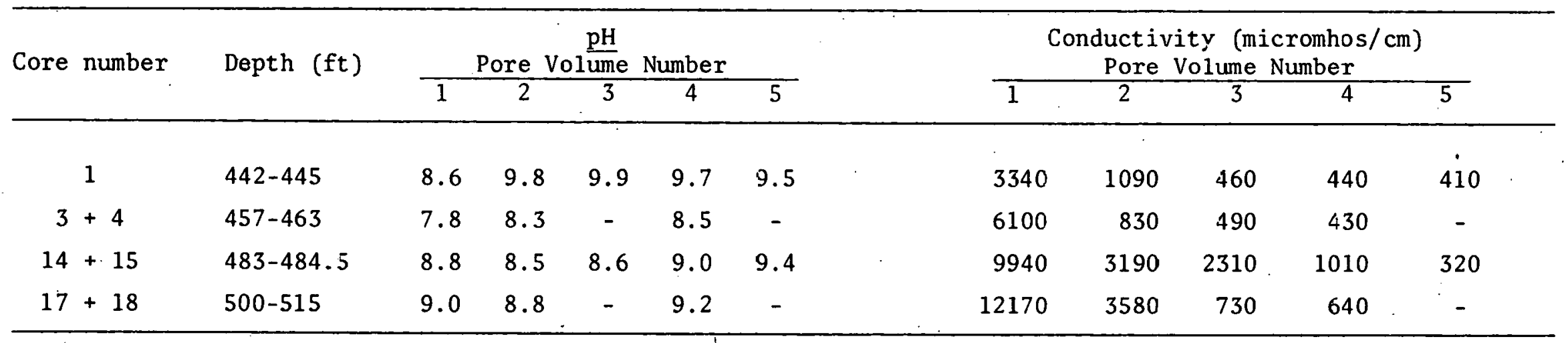

TABLE 4

Concentrations of Dissolved Species in First Pore Volume from Composite Columns of Occidental Retorted Shale

\begin{tabular}{|c|c|c|c|c|c|c|c|c|}
\hline \multirow[b]{2}{*}{ Core number } & \multicolumn{8}{|c|}{ Concentrations in $\mathrm{mg} / \mathrm{\ell}$} \\
\hline & $\overline{\mathrm{S}_{2} \mathrm{O}_{3}}$ & $\mathrm{SO}_{4}$ & $\overline{\mathrm{Ca}}$ & $\mathrm{F}$ & $\mathrm{B}$ & Mo & As & $\overline{\mathrm{Se}}$ \\
\hline 1 & 0 & 990 & 16 & 1.2 & 3.5 & 2.4 & 0.011 & 0.016 \\
\hline $3+4$ & 0 & 2970 & 250 & 2.0 & 2.1 & 0.9 & 0.088 & 0.024 \\
\hline $14+15$ & 260 & 5340 & 180 & 6.9 & 2.6 & 8.8 & 0.160 & 0.100 \\
\hline
\end{tabular}




\section{Table 5}

Boron and Fluoride in Oxy Retort 3E Spent Shale*

\begin{tabular}{cccc}
\hline $\begin{array}{c}\text { Sample } \\
\#\end{array}$ & $\begin{array}{c}\text { Depth } \\
\mathrm{ft} .\end{array}$ & $\begin{array}{c}\mathrm{F} \\
\mathrm{g} / \mathrm{g} \\
\pm 10 \%\end{array}$ & $\begin{array}{c}\mathrm{B} \\
\mu \mathrm{g} / \mathrm{g} \\
\pm 10 \%\end{array}$ \\
\hline 1 & $442-445$ & 470 & 210 \\
3 & $457-460$ & 530 & 140 \\
4 & $460-463$ & 680 & 110 \\
14 & $483-485$ & 1200 & 275 \\
15 & $483.5-485.5$ & 1100 & 210 \\
17 & $500-506$ & 2600 & 470 \\
18 & $506-515$ & 2300 & 550 \\
\hline
\end{tabular}

${ }^{*} \mathrm{~F}:$ Gas diffusion-colorimetric

B: Colorimetric (Azomethine-H)

TABLE 6

Grain Size Distribution and Specific Surface Area of Occidental Retorted Oil Shale (R3E1)

$\frac{\text { Core sample number }}{3+4} \frac{\text { Grain size distribution of sample }}{(---- \text { less than } 100 \text { mesh----- })} \frac{\text { Specific surface area, } \mathrm{m}^{2} / \mathrm{g}}{38.8}$

degassing at $150^{\circ} \mathrm{C}$. Surface charge was determined by electrophoresis in buffered solutions using a commercial Zeta-meter,

Al1 analyses were performed at the University of Colorado with the exception of the surface area determinations which were performed commercially by Coors Analytical Laboratory. 
TABLE 7

Electrophoretic Mobility (micrometers $/ \mathrm{sec}$ per volt $/ \mathrm{cm}$ ) and Zero Point of

Charge of Occidental Retorted Oil Shale (R3E1). Room Temperature.

\begin{tabular}{ccccccccccccccc}
\hline Core sample & 2 & 2.5 & 3 & 4 & 5 & 6 & 7 & 8 & 9 & 10 & 11 & ZPC \\
\hline 1 & -- & -1.0 & -1.2 & -1.5 & -1.6 & -1.6 & -1.7 & -2.0 & -2.3 & -3.2 & -4.0 & $<2.5$ \\
3 & +1.3 & -0.6 & -1.5 & -1.8 & -1.5 & -1.4 & -1.3 & -1.3 & -1.5 & -2.0 & -2.7 & 2.3 \\
4 & -0.3 & -1.5 & -2.0 & -2.1 & -1.8 & -1.7 & -1.7 & -1.8 & -2.0 & -2.8 & -3.4 & 1.8 & -3.7 \\
14 & -- & +1.2 & -1.3 & -1.6 & -1.7 & -1.8 & -1.9 & -2.2 & -2.6 & -3.2 & -3.7 & 2.7 \\
15 & -- & +1.0 & -0.8 & -1.7 & -1.8 & -1.9 & -2.0 & -2.0 & -2.4 & -3.3 & -3.5 & 2.7 \\
17 & -- & 0.0 & -1.4 & -1.7 & -1.9 & -2.0 & -2.1 & -.2. & -2.3 & -3.3 & -3.7 & 2.5 \\
18 & -- & -0.5 & -1.4 & -1.7 & -1.7 & -1.6 & -1.6 & -1.7 & -2.2 & -2.7 & -3.4 & 2.5 \\
\hline
\end{tabular}


onclusions and Discussion

1. A water soluble fraction exists in the Occidental retorted shale from Retort 3E. The amount of water soluble material is dependent on: (i) physical and chemical properties of the shàle which appear to be dependent upon location in the strata, and on (ii) retorting conditions including temperature, recycling of gases, and injection of steam.

2. The concentrations of fluoride, boron, molybdenum, arsenic, and selenium in the initial aqueous leachates are high enough to deserve additional study.

3. The majority of dissolved salts are generally rinsed out of the retorted shale in the first two pore volumes of leachate in contrast to a longer rinse-out period for surface retorted shales. This may reflect the presence of higher temperature silicates in the Occidental material compared to surface retorted shales. (However, the retorted shales, while all ground to eliminate large fragments, were not reduced to a standard mesh size. Differences in grain size could affect the results of the experimental leaching of the samples.)

4. The $\mathrm{pH}$ of the aqueous leachates is intermediate between surface retorted materials. In two of the composite samples (core 1 and core $3+4$ ), the $\mathrm{pH}$ shows a significant increased with the passage of successive pore volumes.

5. In the four columns studied, the concentrations of fluoride in the aqueous leachate in the solid sample systematically increased with depth in the retort. This is probably caused by a greater abundance of fluorine-rich illite near the bottom of the retort.

6. The concentrations of boron in the aqueous leachates and the solid retorted shales show a positive correlation (98.4); however, they do not increase systematically with depth as is the case for fluoride:

7. The aqueous leachates show higher concentrations of sulfate, calcium, selenium, and specific conductance with increasing depth in the retort.

8. Molybdenum and arsenic dissolved in the leachates do not show a systematic increased with depth in the retort.

9. Electrophoresis measurements show that the surface of the Occidental material has a net negative charge above a $\mathrm{pH}$ of approximately 2.7 . We should therefore expect sorption of dissolved cationic species.

10. Measurements of surface area show that the -100 mesh material from a composite of Occidental samples 3 and 4 has $a^{*}$ larger specific surface area than samples of surface retorted materials used in leaching studies at the University of Colorado. Release and sorption of ions may depend on such differences in surface area.

11. X-ray diffraction confirmed the mineralogy of the samples as reported by Occidental. 


\section{LOS ALAMOS SCIENTIFIC LABORATORY}

\section{Materials and Methods}

The approach to the research on the retorted shale from Retort 3E consisted of characterization of the solid material, static leaching experiments followed by trace element analysis of the leachates, and analysis of the data to reveal any behavior patterns as a result of the leaching experiments.

The characterization of the solid material was done using emission spectroscopy, activation analysis, optical microscopy, scanning electron microscopy, electron microprobe interrogation, and $x$-ray diffraction. The results on the minera1 and chemical makeup of the supplied shale samples are described in Chapter 2 of this report.

Static leaching experiments were performed with all sixteen of the samples obtained by LASL (Table 8 ). The experiments were carried out by adding $30 \mathrm{ml}$ distilled water to $6 \mathrm{~g}$ of retorted shale in a capped $60 \mathrm{ml}$ Teflon bottle. The bottles were then shaken at room temperature for 48 hours. Core Samples 1- 4 were filtered using a $0.22 \mu$ filter, the remainder (5-16) through a $0.45 \mu$ filter. These filtrates were then analyzed using atomic absorption spectrophotometry for aluminum, arsenic, boron, calcium, cobalt, chromium, copper, fluoride, iron, magnesium, manganese, molybdenum, sodium, nickel, lead, selenium, vanadium, and zinc. The results of these analyses are shown in Table 8 . The analysis of chromium and nicke1 were below the detection limits of $0.025 \mathrm{ppm}$ and $0.04 \mathrm{ppm}$, respectively; For the purposes of comparison, published multimedia environmental goals (MEG) ${ }^{i}$ expressed as minimum acute toxicity effluents (MATE) are shown on the table for some of the trace elements of environmental concern.

These data were analyzed using a computerized Pearson correlation option. ${ }^{2}$ Using this treatment the correlation coefficients range from +1 to -1 . The results are shown in Figure 2. X-ray diffraction mineralogy 'was done on Core Samples 5 and 16. The results are shown in Table 11 of Chapter 2.

\section{Conclusions and Discussion}

1. Concentrations of trace elements in retorted shale leachates high enough to deserve additional study include aluminum, arsenic, boron, fluoride, selenium, and vanadium. The leaching used is quite different from that proposed by EPA. However, the status of the EPA proposal is presently unclear and the final test proposed may be different from the initial proposal.

2. A statistical analysis of the leachate data shows a slight positive correlation between sample depth and $\mathrm{pH}$ which was largely influenced by Core Samples 4-12.

3. The most significant result of the statistical analysis of the leachate data (Fig. 2) indicates a high correlation between two distinct sets of core samples. One set includes Samples 1, 2, 4, 15, and 16 while the second set includes Samples 3 and 5-13. The x-ray diffraction mineralogy on Samples 5 and 16 (one from each set) tends to reinforce these conclusions. It is recognized that the division into two sets is similar, though not identical, to the filtering behavior. However, these results indicate the possibility that the Retort $3 E$ retorted shale samples can be divided into two families of retorted shale. 
TABLE 8

Trace Element Analyses for Leachates From Oxy's Retort 3E Samples ( $\mu \mathrm{g} / \mathrm{ml})$

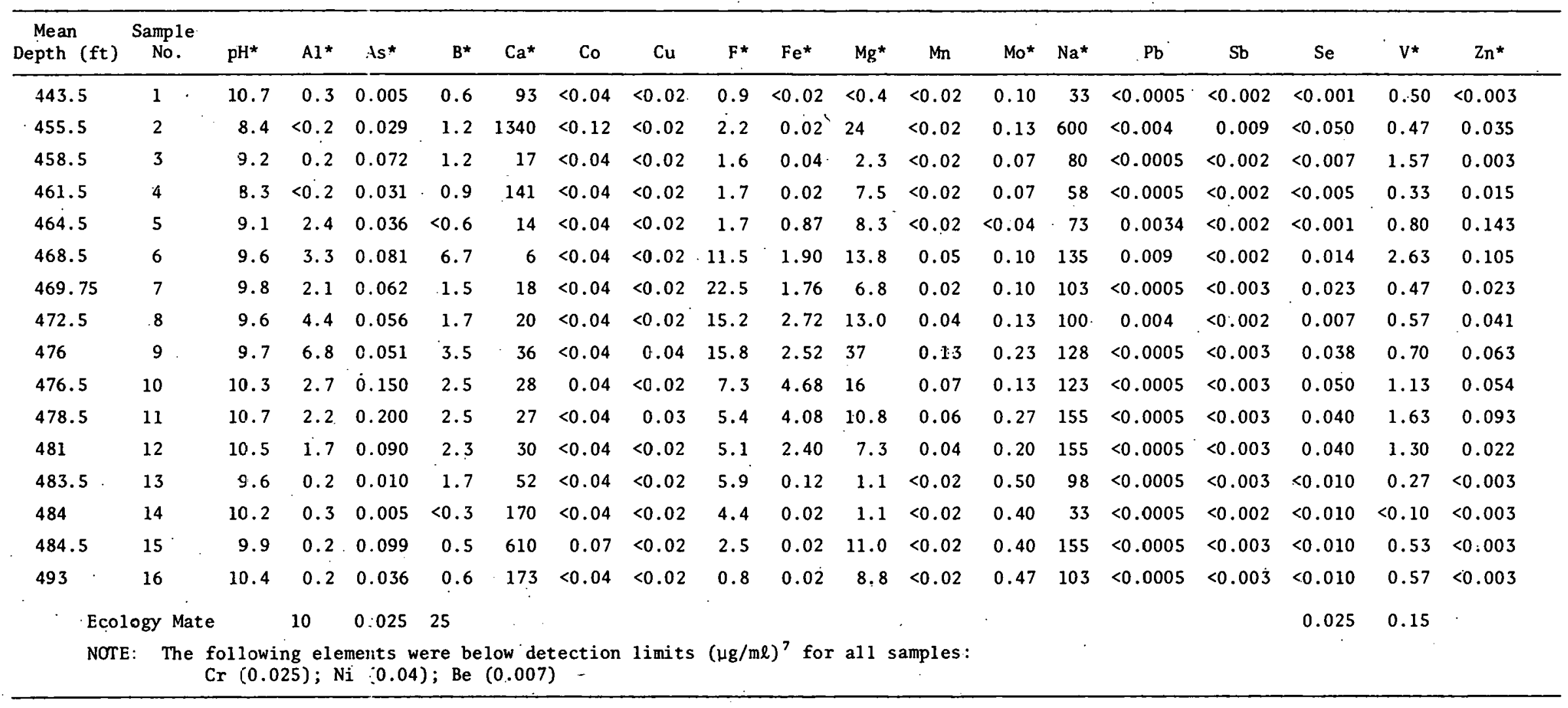

"Used in hierarchical cluster anaiysis study 


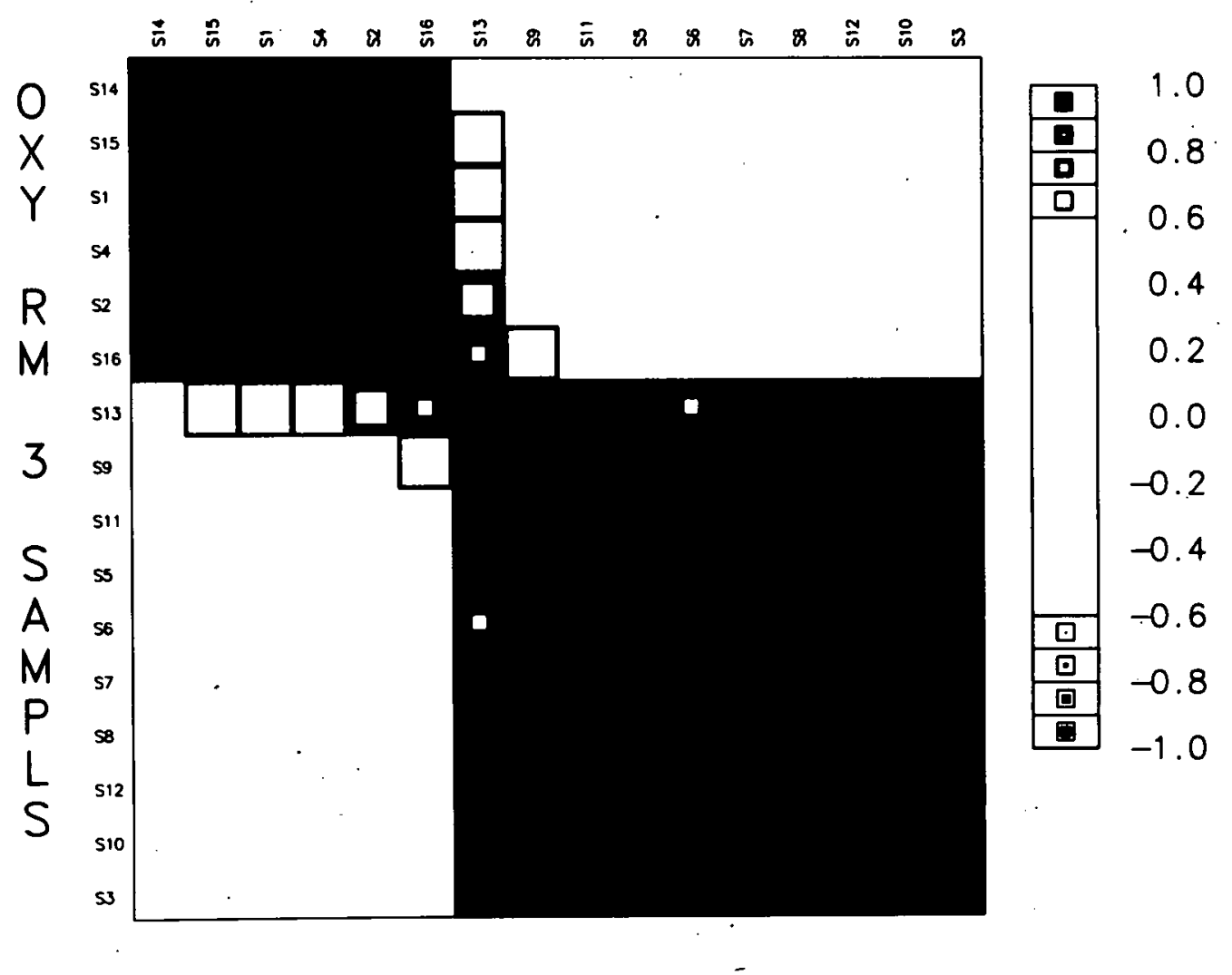

Figure 2. Retort 3E Spent Shale Leachate Sample Correlation. 


\section{BATTELLE-PACIFIC NORTHWEST LABORATORIES}

\section{Materials and Methods}

Column leaching procedures were used in order to obtain sufficient quantities of soluble materials for analysis and mutagenic testing, and because previous 1 aboratory and field studies using retorted shale from an above-ground process have shown that the maximum soluble concentrations of organic carbon and most inorganic species are present in the first one-half column volume $\left(0.5 \mathrm{~V} / \mathrm{V}_{\mathrm{o}}\right)$ of leachate.

The Oxy retorted shale samples were analyzed for organic and total carbon concentrations using a Leco Carbon Analyzer. Due to the limited quantity of solid sample available and the presence of acid soluble organic carbon, the organic carbon determinations were divided into fractions. First, after removal of carbonates by leaching the retorted shale samples with 5\% hydrochloric acid, the organic carbon remaining on the solids was reanalyzed for total carbon, and arbitrarily designated graphitic carbon. Second, the solution obtained was aerated, filtered, and total carbon was determined using a Dohrmann TOC analyzer, and the carbon associated with this fraction was designated HCL-soluble organic carbon. The inorganic carbon [total - (graphitic C + HCL-soluble organic C)] was designated carbonate carbon. Results are presented in Table 9 for both the Oxy and above-ground retorted shale samples. Loss on ignition (LOI) data presented in Table 9 were determined after heating at $900^{\circ} \mathrm{C}$ for 24 hours. Major cations were determined in a bomb digest utilizing nitric, hydrofluoric, and perchloric acids (data not presented).

Two sets of columns were prepared with the 18 oxy samples as we11 as samples of above-ground retorted shale which are to be used for comparison purposes due to more extensive field and laboratory studies on this material. The columns were packed in $0.7 \times 15 \mathrm{~cm}$ glass columns, and the resulting packing densities varied from 0.9 to $1.4 \mathrm{~g} / \mathrm{cc}$. The first set of columns was placed in a glove box containing a water-saturated nitrogen atmosphere. The second set of columns was equilibrated on the bench under aerobic conditions. After a 24 hour equilibration period in the dry condition, distilled water was incrementally added to each column three to four times daily, giving a total of 0.3 to $0.4 \mathrm{ml} / \mathrm{day}\left(0.1\right.$ to $\left.0.2 \mathrm{~V} / \mathrm{V}_{\mathrm{o}}\right)$. The column volume varied with retorted shale type, ranging from 1.60 to $3.1 \mathrm{~m} \ell$. Aliquots were removed for analysis after collecting $1 \mathrm{ml}\left(0.4\right.$ to $\left.0.5 \mathrm{~V} / \mathrm{V}_{0}\right)$. of 1 eachate.

The first leachate aliquot collected from each of the columns was split into two fractions for separate mutagenic testing and chemical analysis.

Chemical analyses, summarized in Table 10, performed on each eluent aliquot ( $1 \mathrm{ml}$ ) included $\mathrm{pH}$, conductivity, total inorganic carbon, total carbon, and major cations ( $\mathrm{Al}, \mathrm{Ba}, \mathrm{B}, \mathrm{Ca}, \mathrm{Cu}, \mathrm{Mg}, \mathrm{Li}, \mathrm{K}, \mathrm{Fe}, \mathrm{Mo}, \mathrm{Mn}, \mathrm{Ni}, \mathrm{Pb}, \mathrm{Si}, \mathrm{Sr}, \mathrm{Ti}, \mathrm{Zn}$, and $\mathrm{Zr}$ ). The $\mathrm{pH}$ measurements were made using an Orion electrode, standardized daily using pH 7 and 10 buffers. Conductivity was measured by a Radiometric conductivity meter equipped with an emersion electrode, cell constant equals 1.0. Total inorganic and total carbon measurements were made on an Oceanographic Carbon Analyzer. 
TABLE 9

Characterization of Carbon in Occidental Core Samples

\begin{tabular}{|c|c|c|c|c|c|}
\hline $\begin{array}{c}\text { Core } \\
\text { Segment No. }\end{array}$ & LOI* & Total C & $\underset{C}{\text { Graphitic }}$ & $\begin{array}{c}\text { HCL } \\
\text { Soluble C }\end{array}$ & Carbonate \\
\hline & $-\cdots$ & 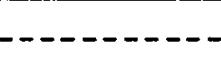 & $\ldots$ & ------ & -------- \\
\hline 1 & 0.81 & 0.50 & 0.16 & 0.34 & $<0.10$ \\
\hline 2 & 24.91 & 5.45 & 0.72 & 0.97 & 18.8 \\
\hline 3 & 19.46 & 3.80 & 0.20 & 0.49 & 15.6 \\
\hline 4 & 7.30 & 1.95 & 0.18 & 0.05 & 8.60 \\
\hline 5 & 20.10 & 3.95 & 0.24 & 0.49 & 16.1 \\
\hline 6 & 17.96 & 2.95 & 0.12 & 0.01 & 14.1 \\
\hline 7 & 9.30 & 2.05 & 0.19 & 0.20 & 8.30 \\
\hline 8 & 10.17. & 1.97 & 0.09 & 0.05 & 1.83 \\
\hline 9 & 12.73 & 2.45 & 0.04 & $<0.01$ & 12.1 \\
\hline 10 & 9.18 & 1.90 & 0.06 & 0.04 & 9.00 \\
\hline 11 & 10.66 & 2.25 & 0.23 & 0.05 & 9.85 \\
\hline 12 & 8.65 & 1.60 & 0.18 & 0.20 & 6.10 \\
\hline 13 & 4.97 & 1.15 & 0.25 & 0.04 & 4.30 \\
\hline 14 & 1.00 & 0.25 & 0.10 & 0.21 & $<0.10$ \\
\hline 15 & 0.63 & 0.30 & 0.25 & 0.05 & $<0.10$ \\
\hline 16 & 0.73 & 0.40 & 0.25 & 0.05 & 0.50 \\
\hline 17 & 0.85 & 0.45 & 0.20 & $<0.01$ & 1.25 \\
\hline 18 & 0.110 & 0.50 & 0.28 & 0.05 & 0.85 \\
\hline $\begin{array}{l}\text { Above-ground } \\
\text { retorted shale }\end{array}$ & 19.34 & 7.05 & 2.50 & 0.21 & 24.0 \\
\hline
\end{tabular}

${ }^{*}$ Loss on ignition at $900^{\circ} \mathrm{C}$ for four hours. 
TABLE 10

Comparison of Concentration Range of Macro Ions Found in the First Fraction of Leachates from Occidental's. Core

Samples and Above-ground Retorted Shale

\begin{tabular}{|c|c|c|}
\hline & \multicolumn{2}{|c|}{ Range of components in } \\
\hline & $\begin{array}{c}\text { Occidental } \\
\text { Core/Samples }\end{array}$ & $\begin{array}{l}\text { Above-ground } \\
\text { Retorted shale }\end{array}$ \\
\hline Quantity of shale in column (g) & $4.0-7.7$ & $3.3-5.5$ \\
\hline Column volume collected $\left(\mathrm{V} / \mathrm{V}_{\mathrm{O}}\right)$ & $0.28-1.11$ & $0.41-0.67$ \\
\hline $\mathrm{pH}$ & $7.75-10.6$ & $10.6-12.2$ \\
\hline Conductivity ( $\mu \mathrm{mho} \cdot \mathrm{s} / \mathrm{cm})$ & $1300-15,000$ & $7600-11,500$ \\
\hline Organic C $(\mu \mathrm{g} / \mathrm{ml})$ & $152-2455$ & $94-205$ \\
\hline Inorganic $\mathrm{C}\left(\right.$ as $\left.\mathrm{CO}_{3}\right)(\mu \mathrm{g} / \mathrm{ml})$ & $30-280$ & $36-170$ \\
\hline Boron $(\mu \mathrm{g} / \mathrm{m} \ell)$ & $1.9-46$ & $3.9-8.5$ \\
\hline Calcium $(\mu \mathrm{g} / \mathrm{m} \ell)$ & $11-513$ & $4-281$ \\
\hline Magnesium $(\mu \mathrm{g} / \mathrm{m} \ell)$ & $0.5-265$ & $<0.5-0.8$ \\
\hline Potassium $(\mu \mathrm{g} / \mathrm{m} \ell)$ & $70-3360$ & $440-830$ \\
\hline Sodium $(\mu \mathrm{g} / \mathrm{m} l)$ & $370-14,400$ & $4800-8100$ \\
\hline Lithium $(\mu \mathrm{g} / \mathrm{m} \ell)$ & $0.2-87$ & $8.4-16.2$ \\
\hline Strontium $(\mu \mathrm{g} / \mathrm{ml})$ & $0.7-10.8$ & $2.4-8.4$ \\
\hline Silicon $(\mu g / m \ell)$ & $5.4-122$ & $15-49$ \\
\hline Zinc $(\mu \mathrm{g} / \mathrm{ml})$ & $<0.01-0.48$ & $<0.01-0.06$ \\
\hline
\end{tabular}

Inorganic carbon was measured by injection into $10 \%$ phosphoric acid and recording the integrated infrared peak of the released carbon dioxide. Total carbon, Table 11, was measured in a similar manner after direct combustion of a portion of the leachate aliquot. Organic carbon was taken as the difference between the total and inorganic carbon values. Major cations were determined by dilution and aspiration into a Jarrel Ash inductively coupled plasma system. Valid results were obtained for barium, boron, calcium, potassium, lithium, sodium, magnesium, silicon, and strontium on all samples. The other elements were bêlow detection limits (ppb range) after the necessary dilution.

Several samples were initially filtered through $0.01 \mu$ filters. However, because of the small sample size (1 ml maximum) of each aliquot, filtration resulted in significant contamination by several elements. Since the samples were clear, filtration was omitted prior to analysis.

The mutagenic testing procedure for the leachate aliquots is described in the Health Effects section of this report. The results of the mutagenic testing are given in Table 13, Chapter 4. 
TABLE 11

Comparison of Organic Carbon Leached from Occidental Core Samples and Above-ground Retorted Shale under

Aerobic and Anaerobic Conditions

\begin{tabular}{clcc}
\hline $\begin{array}{c}\text { Core segment } \\
\text { No. }\end{array}$ & $\begin{array}{c}\text { Leaching } \\
\text { Environment }\end{array}$ & $\begin{array}{c}\text { Column Volume } \\
\left(\mathrm{V} / \mathrm{V}_{\mathrm{O}}\right)\end{array}$ & $\begin{array}{c}\text { Organic C Leached } \\
(\mu \mathrm{g} / \mathrm{g} \text { shale })\end{array}$ \\
\hline 2 & Aerobic & 1.09 & 365 \\
& Anaerobic & 0.73 & 266 \\
5 & Aerobic & 1.00 & 375 \\
7 & Anaerobic & 1.09 & 457 \\
& Aerobic & 1.11 & 68.3 \\
8 & Anaerobic & 0.73 & 49.5 \\
& Aerobic & 0.80 & 53.3 \\
16 & Anaerobic & 0.67 & 40.9 \\
& Aerobic & 0.81 & 417 \\
Above-ground & Anaerobic & 0.83 & 524 \\
retorted shale & Aerobic & 1.47 & 55.2 \\
& Anaerobic & 1.35 & 53.2 \\
& Aerobic & 0.41 & 27.4 \\
& Anaerobic & 0.51 & 41.6 \\
\hline
\end{tabular}

\section{Conclusions and Discussion}

1. The loss on ignition data and weight percent of carbonate in the 0xy samples indicate a rough break of the core into three regions which probably reflect the temperature regime of the retort. The highest temperature or longest period of heating was experienced by Core Sample 1 and Samples 14-18 (lowest LOI and carbonate). Intermediate temperatures and/or a shorter heating duration of heating occurred in Samples 7-13. The lowest temperatures or shortest heating periods occurred within Samples 2-6. In general, this characterization matches the mineralogical record supplied by Oxy (Fig. 1). Although silication reactions occurred throughout the core, a maximum in carbonate persistence occurred in Samples 2-13. The absence of dolomite suggests that all the Retort 3E samples experienced higher temperatures or longer heating times than the above-ground retorted shale. Table 12 summarizes the division of Retort $3 \mathrm{E}$ into three regions based on PNL analysis results, including conductivity, soluble organic carbon, and elemental analyses.

2. Soluble inorganic and organic components are leachable from the Oxy core samples. Most soluble components were leached from the samples in a pulse which occurred at $\mathrm{V} / \mathrm{V}_{\mathrm{O}}<0.5$. The chanacteristic elution profile is depicted in Fig. 3. Although higher concentrations of all organic and inorganic species (Table 10) were associated with the Oxy core samples, leachates with a higher pH were obtained from the above-ground retorted shale. A relatively high concentration of soluble organic carbon $(2455 \mu \mathrm{g} / \mathrm{ml})$ was obtained from Sample 17. 
TABLE 12

Summary of the Mineralogy/Chemistry of Oxy Retort 3E

Zone 1 (442-445 ft/Core Sample 1)

- Higher temperatures $\left(>650^{\circ} \mathrm{C}\right)$

- Loss of carbonate minerals (Ca:Mg 2400:1)

- Silication reactions between quartz and alkaline oxides

- Clinkered, glassey matrix

- Conductivities $2000 \mu \mathrm{mho} / \mathrm{cm}$

- Soluble organic carbon $<200 \mathrm{ppm}$

Zone $2(445-485 \mathrm{ft} /$ Core Samples 2-13)

- Lower temperatures (maximum and/or rate)

- Less decomposition of carbonate minerals $(\mathrm{Ca}: \mathrm{Mg}<150)$

- Conductivities 1300-1400 $\mu \mathrm{mho} / \mathrm{cm}$

- Soluble organic carbon 200-1500 ppm

Zone $3(485-515 \mathrm{ft} /$ Core Samples 14-18)

- Retorting continued

- Liquids, gases condensed on surfaces

- Reduced sulfur species

- Conductivities 5000-11,000 $\mu \mathrm{mho} / \mathrm{cm}$

- Soluble organic carbon 1300-2300 ppm

- Increased solubilities of sulfate, potassium, lithium, fluoride, boron, and selenium

3. The atmospheric conditions under which the laboratory leaching occurred did not significantly affect the composition of the leachates (Table 11). Reduction in $\mathrm{pH}$ and a significant elevation in the carbonate alkalinity of the aerobic leachate occurred, both likely reflecting the increased partial pressure of carbon dioxide. The presence of oxygen had little effect on the magnitude of soluble carbon and the behavior of other components.

4. The total quantity of soluble organic carbon in one column volume is shown in Figure 4. The relatively high concentrations of soluble organic carbon, in comparison to above-ground retorted shale, are probably due to surface adsorbed material. This material could result from the transport and accumulation of soluble components liberated during retorting or from the recycling and condensation of steam containing elevated levels of organic carbon. 


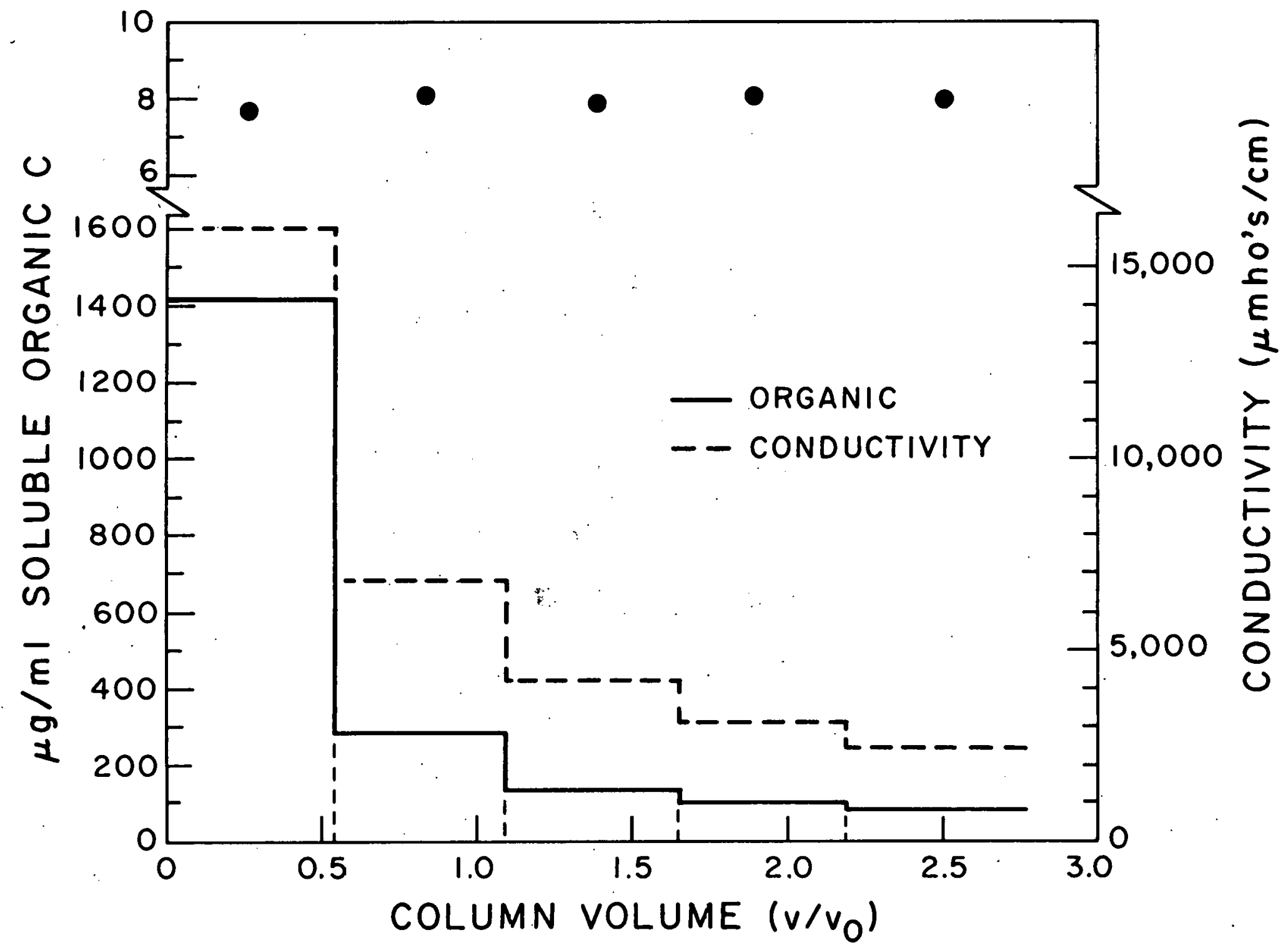

Figure 3. Elution profile of organic carbon, salts, and pH from Occidental core sample, Retort. 3E1, 454-457 feet. 


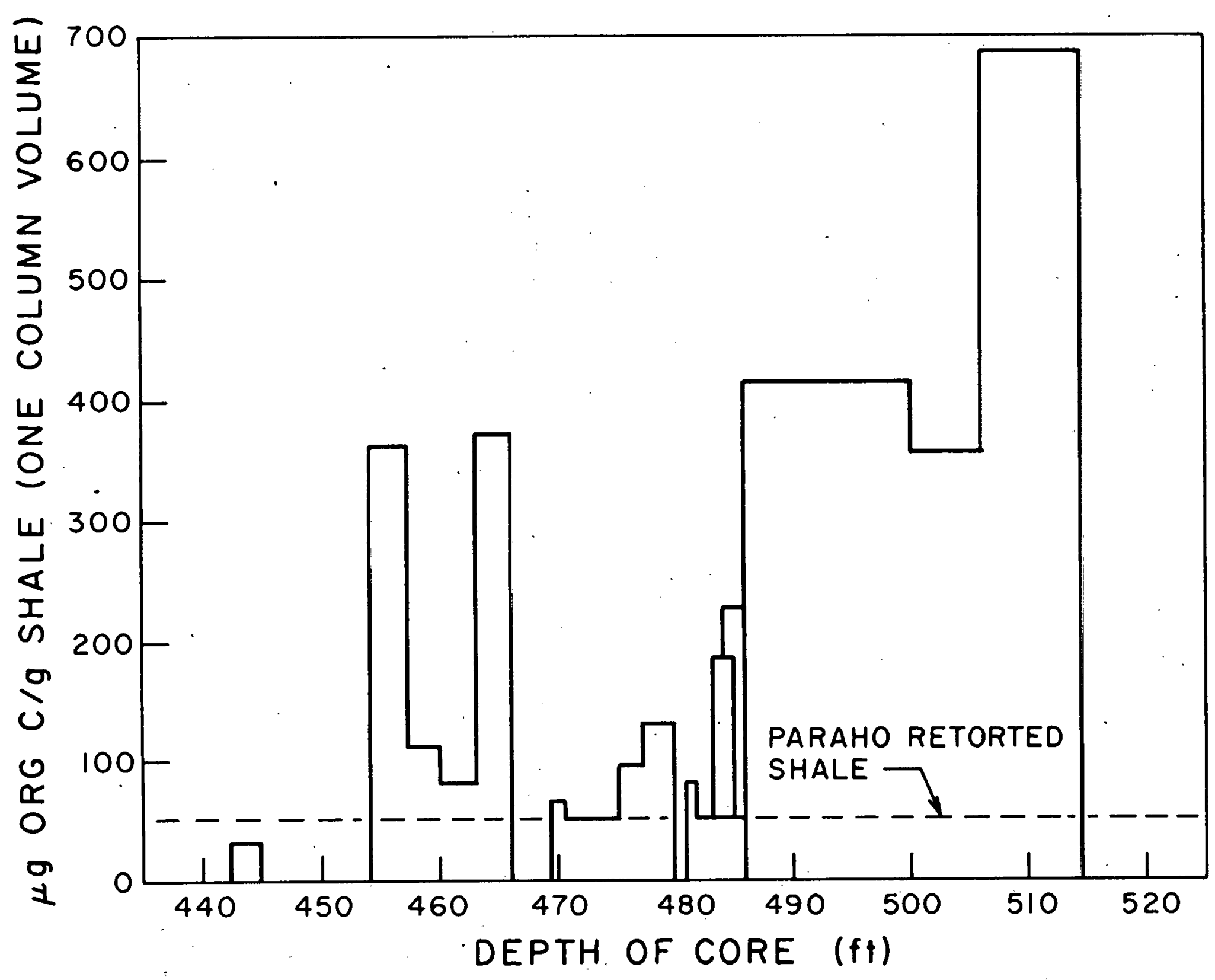

Figure 4. Soluble organic carbon as a function of core depth. 
5. The $\mathrm{pH}$, conductivity, and concentrations of cations and trace metals in the leachates from the individual core samples (data not presented) do not exhibit definitive trends. In general, the cation concentrations and the conductivities of the leachates approximate the zonation suggested by the mineralogical record and the carbonate analyses with increased levels of soluble materials in lower zones of the retort where accumulation of gases and liquids might be expected. However, exceptions exist, and certain core samples (2, 4, 9, and 14) produced leachate with particularly anomalous concentrations.

\section{GENERAL CONCLUSIONS}

Although these leaching study investigations must be considered preliminary, some significant and generalized conclusions can be presented. However, the interpretation of the laboratory results is complicated by: (i) the absence of specific background information on the pre-burn mineralogic and physiochemical character of the core, (ii) the absence of detailed or reliable mineralogic information on several core samples, and (iii) the possibility that solution concentrations reflect the physical processes which have occurred during and after the burn rather than the chemical or mineralogical characteristics of the retorted shale. The reader should consult the previous Conclusions and Discussion sections for the individual laboratories for a more specific and complete 1 ist of conclusions, and for discussion of the conclusions.

1. Although high temperature silication reactions occurred in the oxy MIS retort, a water soluble fraction exists in the retorted shale. The fraction consists of both organics and inorganics, the majority of which are rapidly leached from the retorted shale under the laboratory conditions employed.

2. Both the static shaker and column leaching experiments indicate that the elements arsenic, boron, fluoride, and selenium are sufficiently high in the leachates to be of environmental concern and therefore warrant additional investi:gation to determine whether appropriate control technologies are required. The fact that these concentrations equal or exceed present drinking or irrigation water standards or guidelines does not in itself prove that a significant hazard exists because the leachate will not be directly used for drinking or irrigation water. and therefore are not subject to those standards or guidelines. As these contaminants are transported through the aquifers the concentrations willibe lowered by adsorption, precipitation, and dilution. Modeling of these processes and the transport itself is required in order to determine if the ultimate concentrations in water used for drinking or irrigation are acceptable.

3. The leachates from only a small number of oxy retorted shale samples showed any mutagenic activity. The level of this mutagenic activity was low and comparable to a water extract of Occidental crude shale oil.

4. The analysis of the 18 oxy core samples indicates that the retort can be divided into zones of similar behavior although the division depends heavily on parameters employed. 
The individual laboratories are continuing their research efforts into the leaching of retorted shale samples from Oxy. Emphasis is being placed on clarification of the effect of silication reactions and the retorting parameters on the chemistry of the resulting leachates, on understanding the mechanisms of release and aqueous transport of leached elements, and on the satisfactory explanation of minor differences that exist between Task Force laboratories.

For future leaching studies, it is suggested that cores should be: (i) taken in duplicate, (ii) obtained both prior to and after retorting, and (iii) obtained in greater quantities. Furthermore, detailed attention should be given to the description of the history of the retort and development of protocol to ensure that drilling methods and sample handing do not compromise the integrity of subsequent research.

\section{REFERENCES}

${ }^{2} \mathrm{Clel}$ aud, J.G. and G.L. Kingsbury. Multimedia Environmental Goals, Vols: I and II. U.S. EPA Report 600/7-77-136a,b. November 1977.

${ }^{2} \mathrm{Nil}$, S. et al. IStatistical Package for Social Sciences. McGraw-Hill, New York. 1975, 2nd Ed. 
Chapter 4

HEALTH EFFECTS

\section{INTRODUCTION}

The Health Effects section of this report addresses three major areas of concern:

- Industrial hygiene data collection and sampling.

- Biological studies of materials thought to be important in an overall assessment of risk to either the industrial or regional populations.

- Assessment of current and prospective worker health programs.

These three areas of concern were felt to be the most important at this point in an overall definition of. the potential hazards associated with MIS recovery systems. As a first step, this approach offers the following advantages:

- Industrial hygiene sampling offers the provision of material for chemical analyses and bioassay, and identification of unusual materials or conditions that may be unique, by comparison, to other mining environments.

- Biological studies serve to identify toxic effects--which may be associated with materials and material mixes that are process and/or site specific.

- Assessment of the: health status of current worker population will provide a baseline measurement of individuals entering the industry that will be essential to future epidemiological interpretation.

\section{INDUSTRIAL HYGIENE DATA}

A variety of airborne samples have been collected to characterize occupational health exposures in the Occidental petroleum, Logan Wash facility. Collected samples included Andersen impactors to determine size distribution of airborne particulates, high volume filters to provide sufficient airborne materials for chemical and physical analyses and bioassay testing, small volume filters to determine airborne concentrations of total dust, "Tenax sorbant tubes for determining organic vapor concentrations, alumina sorbant tubes for measuring formaldehyde concentrations and cyclone personal mine dust samplers to determine respirable fraction of airborne dust and free silica fraction of respirable dust. Filter samples were also collected for electron microscopy. Figure 1 indicates sampling locations on the control room level of the facility. Personal samplers were mounted on the wall at positions indicated in Figure 1. 
c] CONTROL OFFICE

(1) SAMPLE POSITION (FILTER, Hi VOI, (MPACTOR)

- RESPIRABLE DUST SAMPLING POSITION $\diamond$ FORMALIN

SAMPLING POSITION

PNLGAS

SAMPLING LOCATION

N TENAX

SAMPLING POSITION

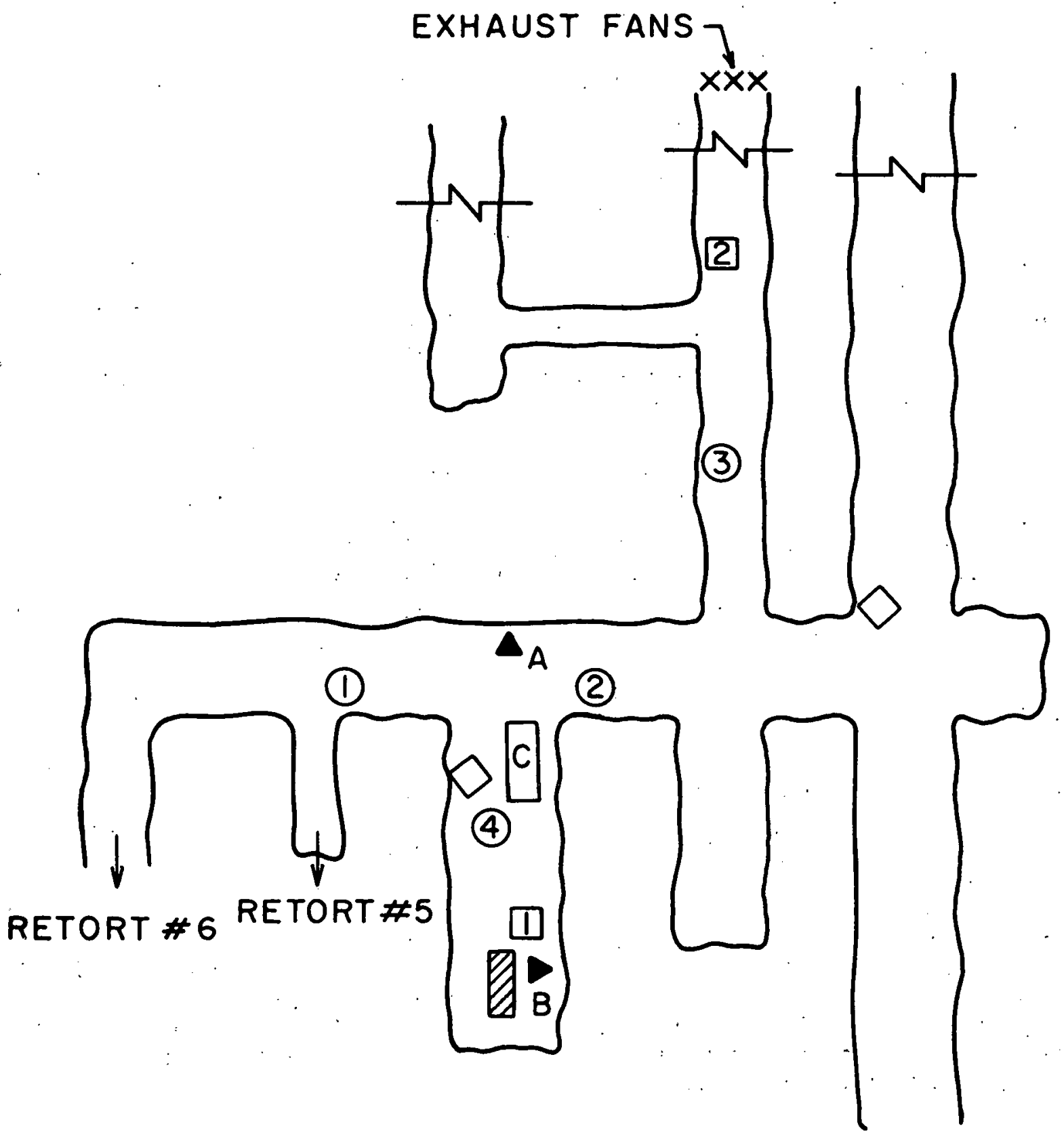

Pigure. 1. Sampling locations on the control room level. 
Particle size determined at these locations is given in Table 1. The respirable fraction was determined by fitting respirable dust curves to the size distribution curves. Total hydrocarbons as a function of particle size were determined by cyclohexane extraction and gravimetric evaluation of residue. The values for two Andersen impactor samples are given in Table 2. This phenomenon may be àn indication of chemical availability as a function of surface area. Scanning electron microscope examination of the particles indicated particles of two distinct physical types--solid compact particles and loosely aggregated porous particles. Most airborne material seemed to be associated with the former type of particles (Figs. 2 and 3). Preliminary examination of several particles by electron microprobe indicate much higher silica content in the solid particles and higher calcium content in the porousiparticles. Particulate standards were not available so only relative information was obtained. In terms of elemental weight percents, the solid particles contained about three times as much silica as the porous particles. The porous particles contained about three times as much calcium as the solid particles. The origin of the porous particles is unknown.

Material collected by the high volume samplers is shown in Table 3 . This material is collected on binder free fiberglass filters. A small portion of the filters have been evaluated for total hydrocarbons (THC) using the NIOSH cyclohexane extraction procedure: The results of these evaluations are given in Table 3A. The average value of THC found on impactor sample taken at Anvil Points is included. These samples will be utilized for additional chemical characterization and for bioassay,

Mine dust personal samplers were used to determine the respirable fraction of airborne dust. These samplers consist of a cyclone pre-separator to remove large "nonrespirable" (as defined by ACGIH criteria) particles followed by a high efficiency filter to collect the "respirable" fraction with a belt mounted pump, flow regulator, and rechargeable battery. To provide low background collection media for free silica analysis silver membrane filters were used. Unfortunately these filters have high pressure drops resulting in rapid battery discharge and the collection of only four reliable samples. The: respirable dust sampler that indicated $1.17 \mathrm{mg} / \mathrm{m}^{3}$ was mounted on the wall of a drift and may have been exposed to dust generated by vehicle traffic.

TABLE 1

Particle Size

\begin{tabular}{cccccc}
\hline Location & Date & $\begin{array}{c}\text { Mass Median } \\
\text { Aerodynamic Diameter }\end{array}$ & $\begin{array}{c}\text { Geometric Std. } \\
\text { Deviation }\end{array}$ & ACGIH* & BMRC* $^{*}$ \\
\hline 1 & $3 / 6 / 79$ & $1.48 \mu \mathrm{m}$ & 3.39 & 69 & 78 \\
1 & $3 / 7 / 79$ & $3.15 \mu \mathrm{m}$ & 4.33 & 50 & 58 \\
1 & $3 / 8 / 79$ & $3.75 \mu \mathrm{m}$ & 3.24 & 46 & 54 \\
2 & $3 / 6 / 79$ & $1.83 \mu \mathrm{m}$ & 3.73 & 63 & 72 \\
3 & $3 / 7 / 79$ & $3.55 \mu \mathrm{m}$ & 2.64 & 48 & 57 \\
\hline
\end{tabular}

$*$

American Congress of Governmental Industrial Hygienists, British Medical Research Council 
TABLE 2

Occidental Andersen Impactor Samples

\begin{tabular}{|c|c|c|c|c|c|}
\hline \multirow[b]{2}{*}{ Stage } & \multirow{2}{*}{$\begin{array}{l}\text { Effective Cut- } \\
\text { off Diameter } \\
(\mu \mathrm{m})\end{array}$} & \multicolumn{2}{|c|}{$A^{*}$} & \multicolumn{2}{|c|}{$\mathrm{C}+\mathrm{T}$} \\
\hline & & THCT & $\%$ Mass** & THCी & $\% \operatorname{MaSS} * *$ \\
\hline 0 & 11 & 1.15 & 12.7 & 1.21 & 7.6 \\
\hline 1 & 11 & 1.47 & 10.9 & 1.36 & 9.2 \\
\hline 2 & 7 & 1.44 & 10.1 & 1.41 & 7.2 \\
\hline 3 & 4.7 & 1.51 & 14.9 & 1.52 & 6.9 \\
\hline 4 & 3.3 & 2.31 & 8.9 & 2.51 & 6.3 \\
\hline 5 & 2.1 & 2.42 & 5.5 & 2.53 & 7.0 \\
\hline 6 & 1.1 & 2.99 & 6.3 & 3.01 & 8.2 \\
\hline 7 & 0.65 & 3.14 & 13.1 & 3.17 & 7.5 \\
\hline $\mathrm{BU}$ & 0.43 & 3.37 & 17.7 & 3.42 & 41.0 \\
\hline
\end{tabular}

* Collected in corridor outside Retort 5 (Location 1).

${ }^{+}$Collected in corridor near control office (Location 2).

"Total hydrocarbon in $\mathrm{mg} / \mathrm{g}$ collected material.

** Mass on stage

$\frac{\text { Mass on stage }}{\text { Total mass collected }} \times 100$ 


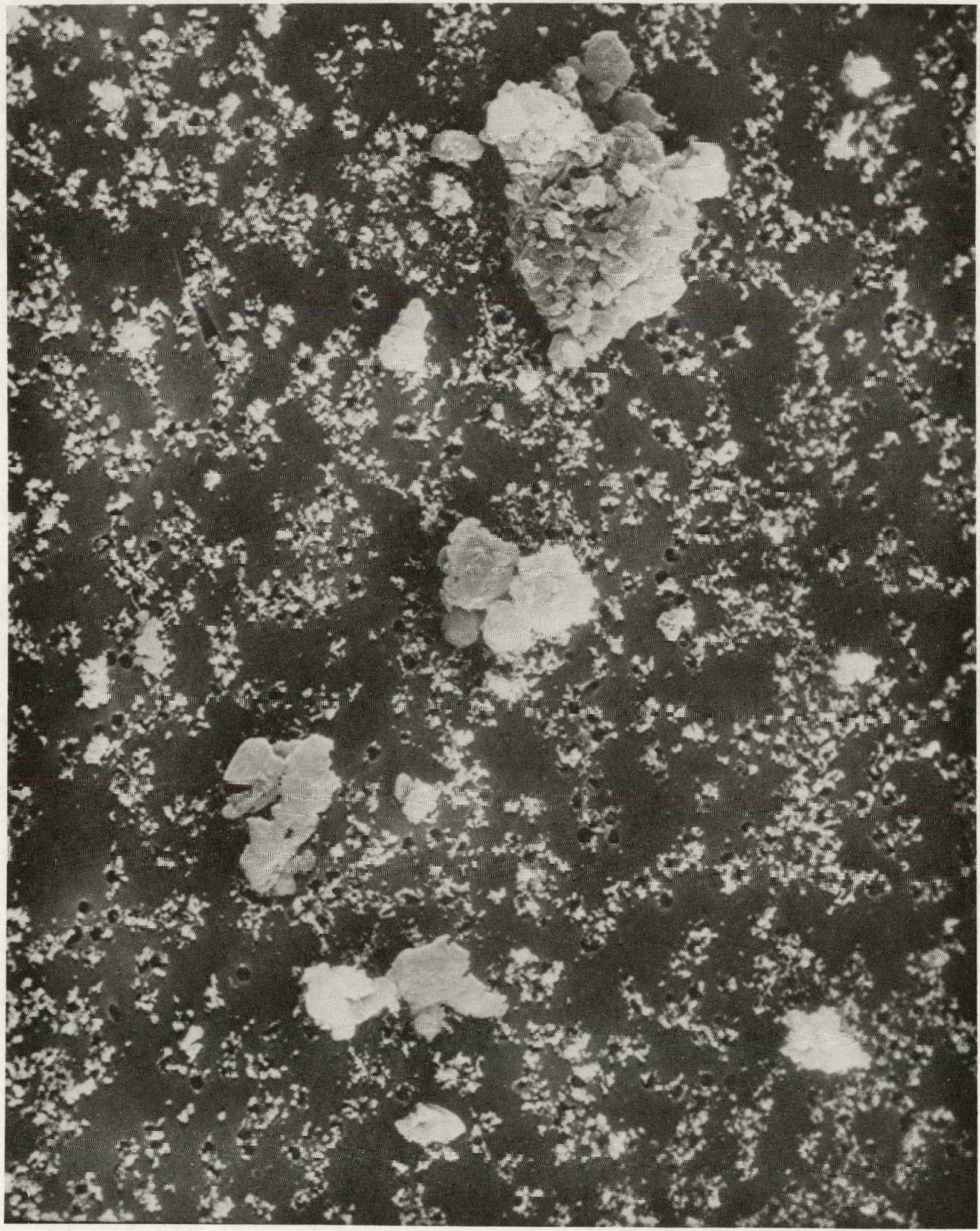

Figure 2. Scanning electron micrograph of the dense, compact particles (x 2000). 


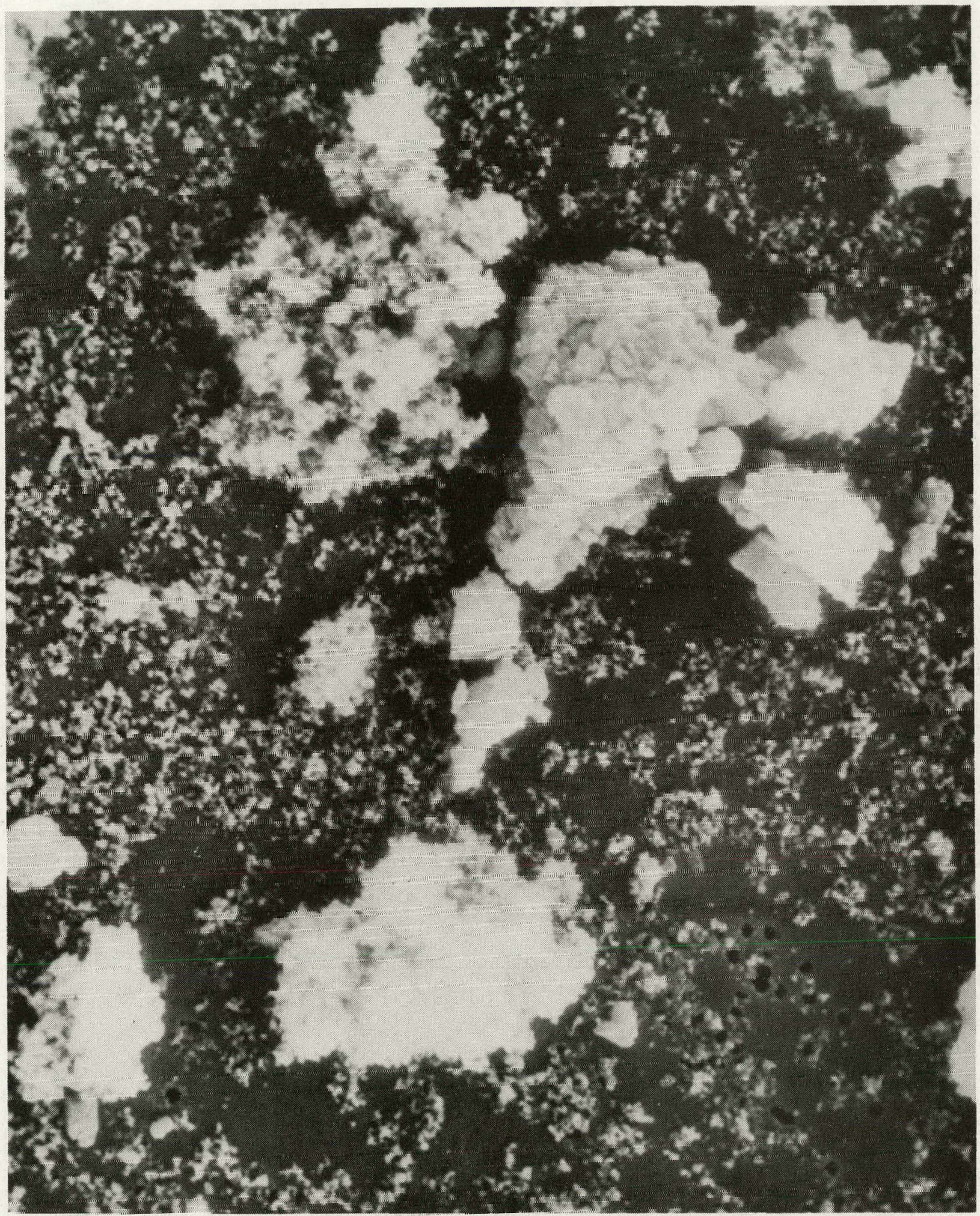

Figure 3. Scanning electron micrograph of the larger, loose amorphous particles (x 2000). 
TABLE 3

High Volume Samples

(Loadings estimated from gross filter samples)

\begin{tabular}{ccc}
\hline Filter No. & Location & Mass mg \\
\hline $101(3 / 6) *$ & 1 & 110 \\
$103(3 / 6)$ & 2 & 65 \\
$101(3 / 7)$ & 1 & 318 \\
$102(3 / 7)$ & 4 & 128 \\
$103(3 / 7)$ & 2 & 116 \\
$104(3 / 7)$ & 3 & 121 \\
$101(3 / 8)$ & 1 & 167 \\
$102(3 / 8)$ & 4 & 98 \\
\hline
\end{tabular}

*A11 dates are 1979 .

TABLE $3 \mathrm{~A}$

High Volume Air Samples

\begin{tabular}{lcc}
\hline Date & $\begin{array}{c}\text { Occidental } \\
\text { NIOSH Extraction } \\
\text { mg }\end{array}$ & THC mg/g \\
\hline $3 / 6 / 79$ & 100 & 2.53 \\
$3 / 7 / 79$ & 316 & 2.61 \\
$3 / 8 / 79$ & 167 & 2.42 \\
\hline
\end{tabular}

Anvil Points

Average THC mg/g--2.10 
The dust concentrations indicated by all dust samplers are shown in Table 4 . Threshold limit values are also shown in Table 4 where these values are calculated assuming $14 \%$ free silica. Free silica measurements were made on the four respirable mass samplers collected on March 6, 1979. The total amount of material collected on these filters was insufficient for accurate determination of free silica. However, al1 samples indicated less than $10 \%$ of the collected mass was free silica. The large fraction of an airborne dust associated with the fine porous particles would support a lower free silica value for airborne material than has been observed in the raw shale material.

Approximately 25 sorbant tube samples of 6 , were collected to determine the concentration of airborne formaldehyde. No detectable levels were measured indicating all measured airborne concentrations were less than $0.2 \mathrm{mg} / \mathrm{m}^{3}$. Tenax absorbant tube samples were collected and will be analyzed to determine airborne concentration of hydrocarbon. High volume samples and Andersen impactor samples are being collected at regular intervals by oxy personnel. These samples are sent to LASL for analyses and storage for additional testing.

\section{BIOLOGICAL STUDIES}

\section{Animal Studies}

\section{Inhalation}

A comparative study with a uniform aerosol concentration $\left(50 \mathrm{mg} / \mathrm{m}^{3}\right.$ of respirable dust) of Anvil Points raw shale and two spent shales from different aboveground processes has been largely completed. Syrian hamsters were exposed for 4 hours/day, 4 days/week for 16 months. Approximately $60 \%$ of the animals in each group are still alive and histological. examination of the pulmonary tissues of animals that have died indicates that spent shale has a more profound effect in the lung than does raw shale dust.

Inhalation of raw shale over long periods resulted in an uncomplicated stimulation of alveolar macrophages which were active in the normal phagocytic processes. In all observed cases this stimulation of macrophages was the major response to the raw product dusts. Inhalation of either spent shale resulted in focal inflammatory responses which included thickening of the interalveolar septa, mild fibrosis, presence of inflammatory cells and proliferation of bronchiolar epithelium. No quantitative distinction between responses to the different types of spent shale can be made at this time.

Current inhalation studies are underway which are designed to compare raw shales from two locations in the Green River formation with Estonian raw shale. These same studies will also be expanded to compare spent shale from the major surface retorting processes with the Estonian spent shale. These experiments will utilize higher exposure concentrations and a second species (rats) in lan effort to further define the variation in response to the materials. 
TABLE 4

Airborne Dust Concentrations $\left(\mathrm{mg} / \mathrm{m}^{3}\right)$

\begin{tabular}{|c|c|c|c|c|}
\hline $\begin{array}{c}\text { Sample } \\
\text { Location }\end{array}$ & $\begin{array}{c}\text { Date } \\
\text { Collected }\end{array}$ & $\begin{array}{c}\text { Total Dust } \\
\text { Filter* } \\
\text { High Vol. }\end{array}$ & $\begin{array}{l}\text { Cascade } \\
\text { Impactor } \\
\text { Andersen }\end{array}$ & $\begin{array}{c}\text { Respirable } \\
\text { Dust } \\
\text { Personal Sampler }\end{array}$ \\
\hline 1 & $3 / 6 / 79$ & 0.39 & 0.31 & 0.21 \\
\hline 1 & $3 / 7 / 79$ & 0.82 & 0.59 & 0.30 \\
\hline 1 & $3 / 8 / 79$ & 0.66 & 1.04 & 0.48 \\
\hline 2 & $3 / 6 / 79$ & 0.38 & 0.24 & 0.15 \\
\hline 2 & $3 / 7 / 79$ & 0.33 & $0.21 \pi$ & -- \\
\hline $1-2$ & $3 / 6 / 79$ & & & $1.17 * *$ \\
\hline 3 & $3 / 7 / 79$ & 0.32 & $0.10 \pi$ & 0.05 \\
\hline 4 & $3 / 6 / 79$ & -- & -- & 0.18 \\
\hline 4 & $3 / 7 / 79$ & 0.54 & -- & -- \\
\hline 4 & $3 / 8 / 79$ & 0.50 & -- & -- \\
\hline
\end{tabular}

${ }^{*}$ TLV assuming $14 \%$ free silica $=1.76 \mathrm{mg} / \mathrm{m}^{3}$.

TLV asssuming $14 \%$ free silica $=0.59 \mathrm{mg} / \mathrm{m}^{3}$.

"Sampler started at end of work day and operated overnight.

${ }^{* *}$ Cyclone located midway between locations 1 and 2 .

Sister Chromatid Exchange (SCE), In Vivo Assay

The induction of SCE in whole mice will be determined at Lawrence Livermore Laboratory (LLL) after in vivo exposure to shale oil products. In these tests, the mice are prepared by implanting BrdUrd pellets. The animals are then challenged with the test material; e.g., five to ight hours 1ater. Whole animals are injected with colcemid to arrest dividing cells at mitosis (2l hrs) and two hours later sacrificed. A number of their tissues are fixed (e.g., bone marrow, spleen, digestive tract) for microscopic observations and both SCEs and chromosome abernations $\mathrm{c}$ an be scored. 


\section{In Vitro Studies}

\section{Ames Test}

Ames test mutagenicity data was presented covering several aspects of the Occidental MIS process. The main emphasis was comparative using shale oil and shale oil by-products produced by the Occidental process versus comparable materials produced by above-ground retorting.with the surface retorting process. Data from two laboratories, PNL and LASL, are presented. In order to facilitate the discussion, a summary of the data from each of these two laboratories will be presented separately, followed by analyses of the results.

The Ames assay using the R-factor containing Salmonelza typhimurium tester strains, TA 98 and TA 100, was used by LASL for analysis of the product shale oil and major effluent streams produced by the Occidental process (Table 5). Dimethylsulfoxide extracts of the oils were prepared and tested while the waters were diulted in sterile deionized water. Two Occidental materials--the product oil and sludge oil--were positive in the test. Strain TA 98 was the best indicator of mutagenesis and no mutagenic activity was detectable without metabolic activation by S9 liver homogenates prepared from Aroclor-induced rats. No mutagenic activity was observed for boiler blowdown, heater-treater water, product water, or pilot plant light oil. The Occidental product (OCCD-CDOL; Table 5) was considerably less mutagenic than surface retort crude oil (Table 5). The surface retort hydrotreated product was less mutagenic than its non-treated precursor. A Louisiana crude petroleum; i.e., a low nitrogen "natural" crude oil, was non-mutagenic, while the ORNL crude was positive (Table 5). (The notable feature of the table is the high mutagenicity of the surface retort crude relative to the Occidental crude shale oil.)

Positive controls--benzo(a)pyrene and 2-aminoanthracene--were strongly positive under the conditions of these Ames assays (Table 6). Surface retort product water was also very active giving 3.4 mutants per microgram of total carbon.

Comparable data dealing with the mutagenicity of surface retort shale oil products was obtained using the TA 98 tester strain at LLL. Table 7 indicates that the product oil is highly mutagenic but that the mutagenicity is lost in the hydrotreated product.

Mutagenicity data presented by PNL was also comparative. This data is summarized in Tables $8 \mathrm{~A}-8 \mathrm{E}$ and Tables 9-13. Tables $8 \mathrm{~A}$ and $8 \mathrm{~B}$ show data obtained in previous work that compared the mutagenicity of two shale oils, surface retort and Livermore retort against a coal distillate, crude petroleums, or pure chemicals. As can be seen, the crude shale, shale oils, or their subfractions obtained by solvent extraction were measurably mutagenic in the Ames assay, but much less so than either the coal distillate (SRC II heavy distillate) or the pure chemicals (2-aminoanthracene and benzo(a)pyrene). : These data serve to place the unfractionated surface retort and Livermore shale oils at the lower end of the mutagenicity scale although they were still more mutagenically active than the crude petroleums. The basic and tar subfractions obtained from all three of the synthetic fuel materials were enriched in mutagenic activity. Localization of mutagens in such fractions is apparently charactexistic of the nitrogen rich synthetic fuels and fuel related materials (SRC II, it should be noted, is a component in a coal liquefaction process). 
TABLE 5

Salmonella/Liver Microsome Histidine Reversion Test

TA 98 Tester Strain

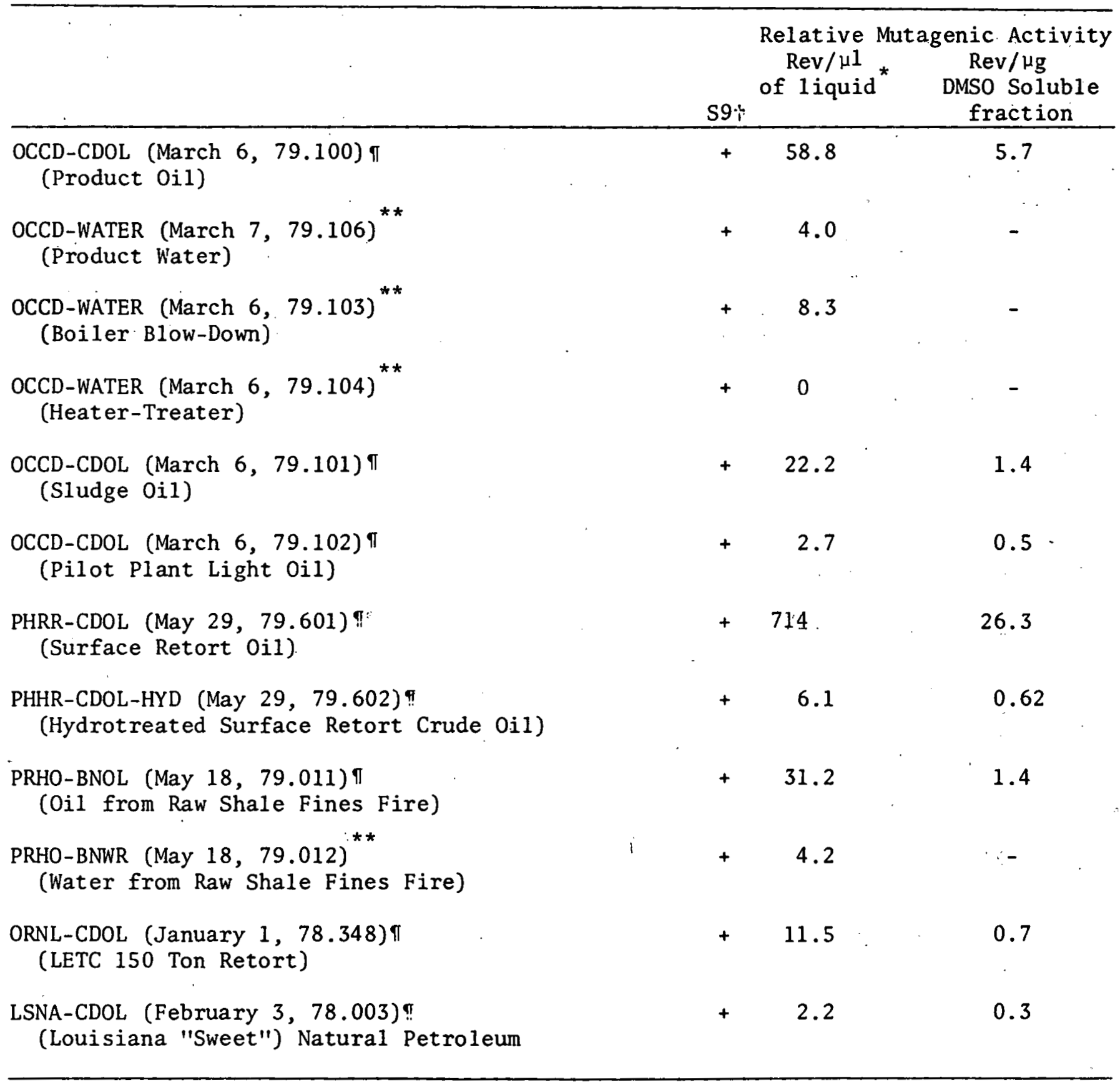

${ }^{*}$ Slopes of 1 inear portions of dose-response curves

†500 $\mu \mathrm{g}$ protein per plate - All materials required activation

ก.

"DMSO-soluble fraction

**No DMSO 
TABLE 6.

Salmonella/Liver Microsome Histidine Reversion Test

\begin{tabular}{|c|c|c|c|}
\hline & Test Strain & s9 ( $\mu \mathrm{g} / \mathrm{Plate})$ & His-rev/jig* \\
\hline Benzo (a)pyrenet & $\begin{array}{ll}\text { TA } & 98 \\
\text { TA } & 100\end{array}$ & $\begin{array}{l}500 \\
500\end{array}$ & $\begin{array}{l}210 \\
100\end{array}$ \\
\hline 2-aminoanthracenet & $\begin{array}{ll}\text { TA } & 98 \\
\text { TA } & 100\end{array}$ & $\begin{array}{l}100 \\
100\end{array}$ & $\begin{array}{l}3,140 \\
2,300\end{array}$ \\
\hline $\begin{array}{l}\text { Surface retort water } \\
\text { (Sept. } 6,78.055) \pi \\
\text { (Product water by separation } \\
\text { in storage tank) }\end{array}$ & $\begin{array}{ll}\text { TA } & 98 \\
\text { TA } & 100\end{array}$ & $\begin{array}{l}500 \\
500\end{array}$ & $\begin{array}{l}3.4 \\
0.36\end{array}$ \\
\hline
\end{tabular}

* Slopes of 1 inear portions of dose-response curve. Values for PRHO-WATER are calculated per microgram of total organic carbon.

+ Solubilized in DMSO

"Diluted in deionized water

TABLE 7

Mutagenicity of Crude and Hydrotreated Shale Oil

Products* and their Water Extracts

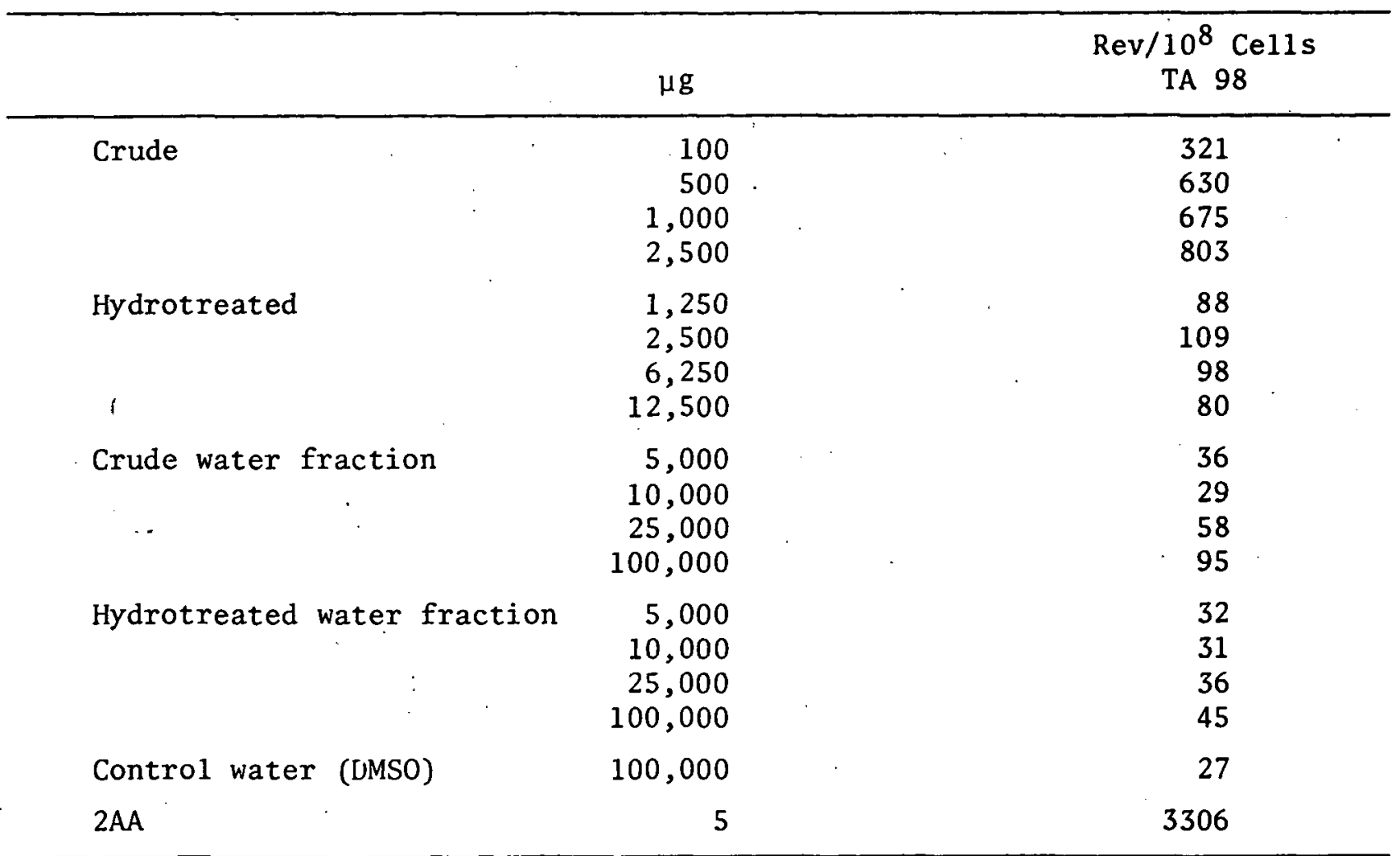

* Above-ground retorting process. 
TABLE $8 \mathrm{~A}$

Ames Assay Data Comparing the Mutagenicities of Several Shale Oils, a Coal Distillate and Two Crude Petroleums

\begin{tabular}{|c|c|c|c|c|}
\hline \multirow[b]{2}{*}{ Fraction } & \multicolumn{4}{|c|}{ Revertants/ug for Salmonella typhimuxizm* } \\
\hline & TA 98 & TA 100 & TA 1538 & TA 1535 \\
\hline $\begin{array}{l}\text { SRC II } \\
\text { Heavy Distillate }\end{array}$ & $\begin{array}{l}40.0 \pm 23 t \\
(0.5-5.0)\end{array}$ & $\begin{array}{l}4.73 \pm 11.7 \pi \\
(50-300)\end{array}$ & $\begin{array}{l}25.41 \pm 11 \\
(10-100)\end{array}$ & $<0.01$ \\
\hline $\begin{array}{l}\text { PRHO-16 } \\
(P-16)\end{array}$ & $\begin{array}{l}0.60 \pm 0.19 \\
(15-600)\end{array}$ & $\begin{array}{l}0.9 \pm 0.24 \\
(80-230)\end{array}$ & & \\
\hline $\begin{array}{l}\text { PRHO-16 } \\
(P-504)\end{array}$ & $\begin{array}{l}0.59 \pm 0.13 \\
(15-600)\end{array}$ & $\begin{array}{l}0.4 \pm 0.3 \\
(50-300)\end{array}$ & & \\
\hline $\begin{array}{l}\text { Livermore } \\
\text { L01 }\end{array}$ & $\begin{array}{l}0.65 \pm 0.22 \\
(16-600)\end{array}$ & $\begin{array}{l}0.9 \pm 0.4 \\
(80-240)\end{array}$ & . & \\
\hline $\begin{array}{l}\text { Prudhoe } \\
\text { Crude }\end{array}$ & $\begin{array}{l}<0.01 \\
(100-1200)\end{array}$ & $\cdot$ & & \\
\hline $\begin{array}{l}\text { Wilmington } \\
\text { Crude }\end{array}$ & $\begin{array}{l}<0.01 \\
(100-1200)\end{array}$ & & & \\
\hline
\end{tabular}

*All results for each assay were normalized to $1 \times 10^{8}$ cells of the indicated $S$. typhimurium test strain. The mutational response for the test was linear with respect to cells over the interval $10^{6}-10^{8}$ cells.

All products were assayed with metabolic activation: SRC, $1000 \mu \mathrm{g}$; shale oil and crude oil, $2500 \mu \mathrm{g}$ Aroclor-induced, hepatic, postmitochondrial (S9) enzyme preparation per plate.

Background revertant colonies for the four test strains were: TA 98, 19; TA 100,192 ; TA 1535,50 ; TA 1538,10 . These values were subtracted from the data in the table.

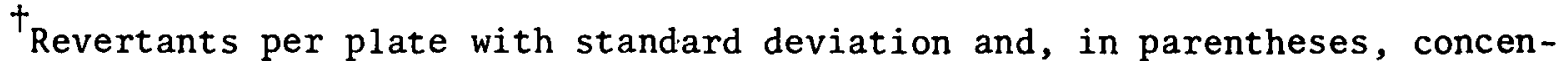
tration:range of linear response for $\mu \mathrm{g}$ fraction per plate. Each concentration was represented by four duplicate samples, which are averaged. Each concentration range included four concentrations over the invervals indicated, and consisted of 16 samples (16 petri plates).

"Where the mutagenic response was nonlinear, the high and low values for mutation are given. The. concentration range (as above) is given in parentheses. 
TABLE $8 \mathrm{~B}$

Ames Assay Comparison of Subfractions Obtained By

Solvent Extraction of Shale Oils and a Coal Distillate

\begin{tabular}{|c|c|c|c|c|}
\hline \multirow[b]{2}{*}{ Subfractions } & \multicolumn{4}{|c|}{ Revertants/ug for Salmonella typhimurium* } \\
\hline & TA 98 & TA 100 & TA 1538 & TA 1535 \\
\hline $\begin{array}{l}\text { SRC II Heavy } \\
\text { Distillate Basic }\end{array}$ & $\begin{array}{l}400 \pm 70 t \\
(0.5-5)\end{array}$ & $\begin{array}{l}9.1-58 \\
(50-600)\end{array}$ & $\begin{array}{l}278 \pm 87 \\
(10-40)\end{array}$ & $<0.1$ \\
\hline $\begin{array}{l}\text { SRC II Heavy } \\
\text { Distillate Basic } \\
\text { Tar }\end{array}$ & $\begin{array}{l}66 \pm 16.4 \\
(2.5-10\end{array}$ & $\begin{array}{l}4-13 \\
(50-600)\end{array}$ & $\begin{array}{l}72.8 \pm 32 \\
(10-160)\end{array}$ & $<0.1$ \\
\hline $\begin{array}{l}\text { SRC II Heavy } \\
\text { Distillate Neu:- } \\
\text { tral Tar }\end{array}$ & $\begin{array}{l}108-317 \pi \\
(0.5-10)\end{array}$ & $\begin{array}{l}2.3-9.7 \\
(50-600)\end{array}$ & $\begin{array}{l}38.1 \pm 17 \\
(10-160)\end{array}$ & $<0.1$ \\
\hline $\begin{array}{l}\text { PRHO- } 16 \\
\text { Basic }\end{array}$ & $\begin{array}{l}2.11 \pm 0.6 \\
(15-130)\end{array}$ & $\begin{array}{l}2.13 \pm 0.4 \\
(50-250)\end{array}$ & & \\
\hline $\begin{array}{l}\text { PRHO- } 16 \\
\text { Tar }\end{array}$ & $\begin{array}{l}1.00 \pm 0.4 \\
(30-600)\end{array}$ & $\begin{array}{l}2.37 \pm 0.9 \\
(50-200)\end{array}$ & $\cdot$ & \\
\hline $\begin{array}{l}\text { PRHO-504 } \\
\text { Basic }\end{array}$ & $\begin{array}{l}3.98 \pm 0.4 \\
(15-130)\end{array}$ & $\begin{array}{l}1.69 \pm 6.13 \\
(60-300)\end{array}$ & & \\
\hline $\begin{array}{l}\text { PRHO-504 } \\
\text { Tar }\end{array}$ & $\begin{array}{l}0.24 \pm 0.10 \\
(30-600)\end{array}$ & $\begin{array}{l}0.50 \pm 1.44 \\
(60-300)\end{array}$ & & \\
\hline $\begin{array}{l}\text { Livermore L01 } \\
\text { Basic }\end{array}$ & $\begin{array}{l}2.88 \pm 0.9 \\
(15-130)\end{array}$ & $\begin{array}{l}1.58 \pm 0.1 \\
(50-250)\end{array}$ & & \\
\hline $\begin{array}{l}\text { Livermore L01 } \\
\text { Tar }\end{array}$ & $\begin{array}{l}0.4-3.3 \\
(30-600)\end{array}$ & $\begin{array}{l}2.10 \pm 0.2 \\
(50-250)\end{array}$ & & \\
\hline $\begin{array}{l}\text { 2-Aminoanthra- } \\
\text { cene }\end{array}$ & $\begin{array}{l}4326 \pm 282 \\
\quad(\mathrm{SRC} \text { II })^{* *} \\
7886 \pm 1196(\mathrm{SO})\end{array}$ & 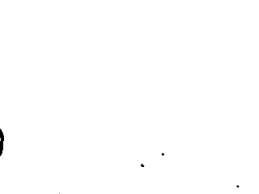 & $\therefore$ & \\
\hline Benzo(a)pyrene & $\begin{array}{l}114 \pm 5 \\
(\mathrm{SRC} \text { II }) \text { ** } \\
202 \pm 75(\mathrm{SO})\end{array}$ & . & & \\
\hline
\end{tabular}

* All results for each assay were normalized to $1 \times 10^{8}$ cells of the indicated S. typhimurizm test strain. The mutational response for the test was linear with respect to cells over the interval $10^{6}-10^{8}$ cells.

All products were assayed with metabolic activation: SRC, $1000 \mathrm{\mu g}$; shale oil and crude oil, $2500 \mu \mathrm{g}$, Aroclor-induced, hepatic, postmitochondrial (S9) enzyme preparation per plate. 
TABLE 8B (continued)

Background revertant colonies for the four test strains were: TA 98, 19; TA 100,192 ; TA 1535,$50 ;$ TA 1538,10 . These values were subtracted from the data in the table.

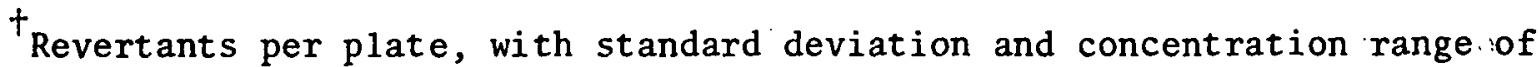
linear response, are given in parentheses for $\mu \mathrm{g}$ fraction per plate. Each concentration was represented by four duplicate samples, which are averaged. Each concentration range included four concentrations over the intervals indicated, and consisted. of 16 samples (16 petri plates).

"Where the mutagenic response was nonlinear, the high and low values for mutation are given. The concentration range (as above) is given in parentheses.

"The designation in brackets indicates the complex sample corresponding to a given value of the positive control.

In comparable work done at PNL, the Occidental crude shale oil and the Occidental sludge oil (a process stream) were assayed for mutagenicity against four of the Ames tester strains: TA 98 and TA 100 and their non R-factor containing homologs, TA 1538 and 1353 (Table 8C). In contrast to the data obtained with the surface retort and Livermore samples, no mutagenic activity was detectable in either crude material. However, in PNL hands, crude materials, and shale oils in particular, tend to produce non-linear dose-response data, and in certain instances even surface retort crude oils which are normally positive in the Ames assay (i.e., mutagenic responses greater than $2.0 \mathrm{x}$ background), can give spurious negative results due to either toxicity to the target cells or interference with the metabolic activation process catalyzed on the 59 homogenates. :This problem can. be alleviated by fractionation of crudes by various methods including solvent extraction, thin-1ayer chromatography (TLC), and gel permeation column chromatography to remove interferring components.

PNL applied both TLC and gel permeation chromatography on Syhadex LH20 to fractionate the Occidental product oil and sludge oil for analysis by the Ames assay. Results of the ge1 permeation experiments are presented by the data in Table 8D. The crudes fractionated by this procedure were split into three fractions: one eluted with hexane which contained neutral compounds (e.g., polynuclear aromatics); a hexane/toluene eluate that contained moderately polar compounds; and a methanol eluate that contained strongly polar compounds.

These three fractions derived from Occidental product oil were not mutagenic in the Ames assay (Table $8 \mathrm{C}$ ), confirming results obtained with the crude (unfractionated) material. On the other hand, the methanol fraction from Occidental sludge oil (non-mutagenic as the crude material) was mutagenic in the Ames assay. This fraction constituted less than $1 \%$ of the total mass of the sludge oil (Table 8D). The specific mutagenic activity was fairly constant in concentrations of

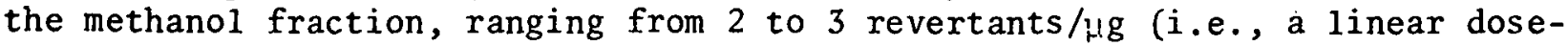
response relationship); and was comparable to the basic subfractions of the surface retort and Livermore shale oils (Table $8 \mathrm{~B}$ ) assayed for mutagenicity in previous work. 
TABLE $8 \mathrm{C}$

Ames Data for Occidental Crude Product Shale Oil and Occidental Sludge Oil: Unfractionated Crude Materials

\begin{tabular}{lcclll}
\hline Sample & $\mu \mathrm{g}$ assayed & TA 98 & TA 100 & TA 1538 & TA 1535 \\
\hline Occidental & 500 & nil $(-23)^{*}$ & nil $(-62)$ & nil $(-20)$ & nil $(-2)$ \\
product oil & 1000 & nil $(-14)$ & nil $(0)$ & nil $(-8)$ & nil $(-2)$ \\
Occidental & 1078 & nil $(-10)$ & N.D. & N.D. & N.D. \\
sludge oil & 2150 & nil $(-9)$ & & & \\
\hline
\end{tabular}

*Nil indicated that the numerical difference between the average of two experimental samples and the average background rate of mutation are less than or equal to zero. The number inside the parentheses is the numerical difference between sample average and background.

Backgrounds: $\mathrm{TA} 98=66 \pm 10$; TA $100=102 \pm 22$; TA $1538=53 \pm 5$; TA $1535=55 \pm 7$. Each value represents the average and standard deviations for six negative control (i.e., background) petri plates.

Metabolic activity was provided by $810 \mu \mathrm{g}$ S9 homogenate protein per sample assayed.

N.D. = not determined

For comparison with the Occidental materials, surface retort and Livermore shale oils and a coal distillate (SRC II heavy distillate) were fractionated and analyzed for mutagenicity following the same procedure (Table 8C). All three crudes yielded active mutagenic methanol fractions similar in their specific mutagenic activities to those obtained by solvent extraction (Table 8B). The hexane and hexane/ toluene fractions were of substantially lower mutagenicity (coal distillate) or without mutagenicity (shale oils).

Recovery of materials in these methanol fractions was again a small percent of the total amount of material applied to the LH 20 column; i.e., ranging from $1 \%$ (SRC II) to $3.4 \%$ (surface). However, total recoveries of mass were good in all cases (Table 8E).

Water extracts made from the Occidental and surface retort oils were tested for their mutagenicity in the Ames assay (Tables 9 and 10). The pH 5 and $\mathrm{pH} 8$ extracts of Occidental crude oil were weakly positive in the test, but with little or no indication of a dose response (Table 9). Thus the mutagenicity of these aqueous extracts must be considered borderline. Extracts of the surface retort crude oil, on the other hand, gave clearly positive results in the assay with increasing mutational response with increasing concentrations of organic carbon (Table 10). The specific activity of the surface retort aqueous extracts were comparable to values usually observed for the crude oil (Table $8 \mathrm{~A}$ ). 
TABLE 8D

Ames Assay of LH20 Column Fractions of Several

Shale Oils and a Coal Distillate

\begin{tabular}{|c|c|c|c|c|c|}
\hline \multirow[b]{2}{*}{ Sample } & \multirow[b]{2}{*}{ assayed } & \multicolumn{2}{|c|}{ Revertants TA 98} & \multicolumn{2}{|c|}{ 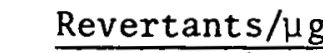 } \\
\hline & & a. & b. & a. & $\mathrm{b}$ \\
\hline $\begin{array}{l}\text { Occidental product oil (Oxy) } \\
\text { hexane fraction* }\end{array}$ & $\begin{array}{l}386 \\
772\end{array}$ & $\begin{array}{l}27 t \\
31\end{array}$ & $\begin{array}{l}16 \\
17\end{array}$ & & \\
\hline $\begin{array}{l}\text { Oxy-hexane/toluene } \\
\text { fraction }\end{array}$ & $\begin{array}{l}25 \\
50\end{array}$ & $\begin{array}{l}36 \\
30\end{array}$ & $\operatorname{nil}_{3}(-14)$ & & \\
\hline $\begin{array}{l}\text { Oxy-methanol } \\
\text { fraction }\end{array}$ & $\begin{array}{l}11 \\
22\end{array}$ & $\begin{array}{l}33 \\
35\end{array}$ & $\begin{array}{l}12 \\
14\end{array}$ & & \\
\hline $\begin{array}{l}\text { Occidental sludge oil (Oxys) } \\
\text { hexane fraction }\end{array}$ & $\begin{array}{l}2156 \\
4312\end{array}$ & & $\begin{array}{l}\operatorname{nil}(-15) \\
\operatorname{nil}(-8)\end{array}$ & & \\
\hline $\begin{array}{l}\text { OxyS-hexane/toluene } \\
\text { fraction }\end{array}$ & $\begin{array}{l}40 \\
80\end{array}$ & $\begin{array}{l}\operatorname{nil}(-6) \\
\operatorname{nil}(-18)\end{array}$ & $\begin{array}{l}\operatorname{nil}(-3) \\
\operatorname{nil}(-2)\end{array}$ & & \\
\hline $\begin{array}{l}\text { OxyS-methanol } \\
\text { fraction }\end{array}$ & $\begin{array}{l}24 \\
48\end{array}$ & $\begin{array}{r}61 \\
137\end{array}$ & $\begin{array}{r}51 \\
132\end{array}$ & $\begin{array}{l}2.5 \\
2.9\end{array}$ & $\begin{array}{l}2.1 \\
2.0\end{array}$ \\
\hline $\begin{array}{l}\text { Above-ground process product oil } \\
(A G) \text {, hexane fraction }\end{array}$ & $\begin{array}{l}2018 \\
4036\end{array}$ & $\begin{array}{l}\operatorname{nil}(-1) \\
\operatorname{nil}(-13)\end{array}$ & $\begin{array}{l}1 \\
6\end{array}$ & . & \\
\hline $\begin{array}{l}\text { AG-hexane/toluene } \\
\text { fraction }\end{array}$ & $\begin{array}{r}50 \\
100\end{array}$ & $\begin{array}{l}9 \\
2\end{array}$ & $\begin{array}{l}62 \\
81\end{array}$ & & \\
\hline AG-methanol fraction & $\begin{array}{r}39 \\
78 \\
156\end{array}$ & $\begin{array}{l}122 \\
291 \\
511\end{array}$ & $\begin{array}{l}200 \\
255 \\
351\end{array}$ & $\begin{array}{l}3.1 \\
3.7 \\
3.3\end{array}$ & $\begin{array}{l}5.1 \\
3.3 \\
2.2\end{array}$ \\
\hline $\begin{array}{l}\text { Livermore product oil (LOl) } \\
\text { hexane fraction }\end{array}$ & $\begin{array}{l}448 \\
896\end{array}$ & $\begin{array}{l}29 \\
28\end{array}$ & $\begin{array}{l}18 \\
16\end{array}$ & & \\
\hline $\begin{array}{l}\text { Lol-hexane/toluene } \\
\text { fraction }\end{array}$ & $\begin{array}{l}10 \\
20\end{array}$ & $\begin{array}{l}48 \\
.73\end{array}$ & $\begin{array}{l}60 \\
65\end{array}$ & & \\
\hline L01-methanol fraction & $\begin{array}{r}85 \\
17 \\
34\end{array}$ & $\begin{array}{r}64 \\
123 \\
165\end{array}$ & $\begin{array}{r}88 \\
139 \\
214\end{array}$ & $\begin{array}{l}9.4 \\
7.4 \\
5.0\end{array}$ & $\begin{array}{r}10.3 \\
8.2 \\
6.3\end{array}$ \\
\hline $\begin{array}{l}\text { SRC. II, heavy distillate (HD) } \\
\text { hexane fraction }\end{array}$ & $\begin{array}{l}109 \\
218\end{array}$ & & $\begin{array}{l}58 \\
92\end{array}$ & & $\begin{array}{l}0.6 \\
0.4\end{array}$ \\
\hline $\begin{array}{l}\mathrm{HD} \text {-hexane/toluene } \\
\text { fraction }\end{array}$ & $\begin{array}{l}22 \\
44\end{array}$ & . & $\begin{array}{l}172 \\
313\end{array}$ & . & $\begin{array}{l}7.8 \\
7.2\end{array}$ \\
\hline HD-methanol fraction & $\begin{array}{l}0.6 \\
1.2 \\
3.0\end{array}$ & & $\begin{array}{l}210 \\
319 \\
898\end{array}$ & & $\begin{array}{l}350 \\
266 \\
300\end{array}$ \\
\hline 2-aminoanthracene & 1 & 2460 & 2501 & 2460 & 2501 \\
\hline Benzo (a)pyrene & 2.5 & 380 & 445 & 141 & 180 \\
\hline
\end{tabular}


TABLE 8D (continued)

* $\mu \mathrm{g}$ shale oil or coal distillate remaining after LH20 column solvent (hexane, hexane/toluene, or methanol) removed by evaporation.

${ }^{\dagger}$ Each value represents the average of two samples (separate experiments) minus the background for that experiment. Nil values, as defined in Table 8C. Backgrounds $=31 \pm 8$ (6 samples, exp. a.), $28 \pm 9$ (6 samples, exp. b.) Metabolic activation was provided by $810 \mu \mathrm{g}$ of 59 homogenate proteint (Aroclor induced) per sample assayed.

TABLE $8 \mathrm{E}$

Recovery of Material after LH2O Column Chromatography Column Fraction $(\mu \mathrm{g})$ *

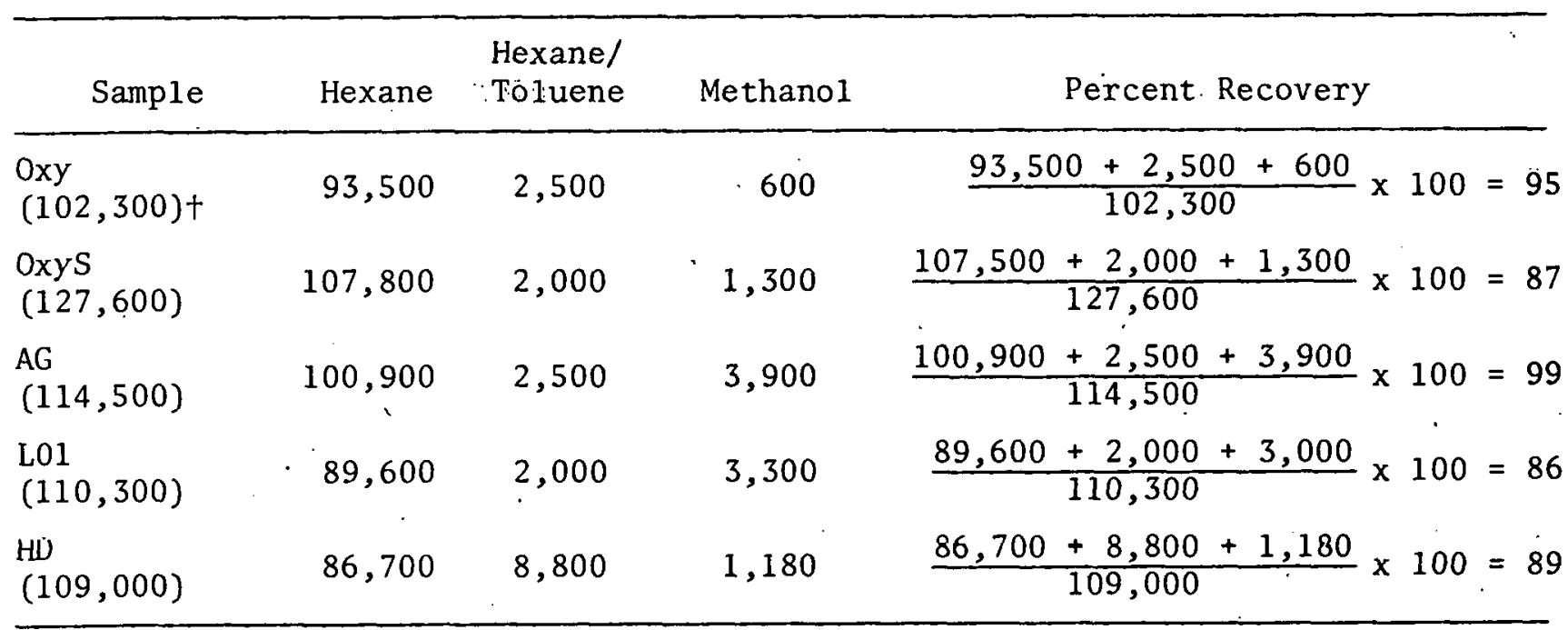

* $\mu$ g synthetic fuel material (remaining) after solvents (hexane, hexane/toluene, or methanol) removed by evaporation.

+ Amount of material chromatographed. 
TABLE 9

Mutagenicity of Shale Oil and Water Extracts of Oil

Produced by the Occidental Modified In Situ Process

\begin{tabular}{|c|c|c|c|}
\hline Sample & $\begin{array}{l}\mu g \text { Organic } \\
\text { Carbon }\end{array}$ & $\begin{array}{l}\text { Net Revertants } \\
\text { (TA 98)* }\end{array}$ & Revertants/ $\mu \mathrm{g}$ \\
\hline \multirow{4}{*}{$\begin{array}{c}\text { Water Extract } \\
\text { pH } 5\end{array}$} & 12 & 0 & \multirow[t]{2}{*}{0} \\
\hline & 29 & 6 & \\
\hline & 58 & 20,16 & 0.35 \\
\hline & 86 & 24 & 0.29 \\
\hline \multirow{5}{*}{$\begin{array}{l}\text { Water Extract } \\
\quad \mathrm{pH} 8\end{array}$} & 120 & 50 & 0.43 \\
\hline & 29 & 8 & 0.26 \\
\hline & \multicolumn{3}{|c|}{ 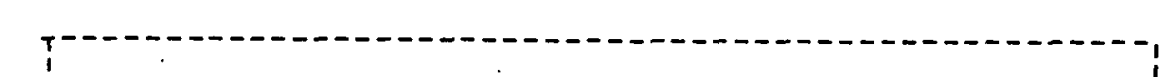 } \\
\hline & 76 & 47,30 & $0.65,0.43$ \\
\hline & 150 & 46 & 0.32 \\
\hline \multirow[t]{2}{*}{ Crude Oil } & 740 & 11 & 0.01 \\
\hline & 1,500 & 4 & $<0.01$ \\
\hline
\end{tabular}

* Average of two samples minus background

Data inside dotted lines is positive or weakly positive; i.e., $2 \mathrm{x}$ above background mutations.

Background $=50 \pm 12$ revertant colonies (12 samples)

Metabolic activation provided by $810 \mu \mathrm{g}$ of $\mathrm{S} 9$ homogenate protein per assay 
TABLE 10

Mutagenicity of Shale Oil and Water Extracts Produced By an Above-Ground Retorting Process

\begin{tabular}{|c|c|c|c|}
\hline Sample & $\begin{array}{c}\mu g \text { Organic } \\
\text { Carbon }\end{array}$ & $\begin{array}{l}\text { Net Revertants } \\
\text { (TA 98)* }\end{array}$ & Revertants $/ \mu \mathrm{g}$ \\
\hline \multirow{5}{*}{$\begin{array}{c}\text { Water Extract } \\
\text { pH } 5\end{array}$} & 37 & 11 & 0.3 \\
\hline & 93 & 58 & 0.6 \\
\hline & 190 & 115,239 & $0.6,1.3$ \\
\hline & 280 & 212 & 0.8 \\
\hline & 370 & 282 & 0.8 \\
\hline \multirow{3}{*}{$\begin{array}{c}\text { Water Extract } \\
\text { pH } 8\end{array}$} & 92 & 49 & 1.1 \\
\hline & 230 & 91,199 & $0.4,0.9$ \\
\hline & 460 & 301 & 0.7 \\
\hline \multirow{2}{*}{ Crude Oil } & 750 & 20 & 0.03 \\
\hline & 1,500 & 26 & 0.01 \\
\hline
\end{tabular}

\footnotetext{
*Average of two samples minus background

Background $=50 \pm 12$ revertant colonies (12 samples)

Metabolic activation provided by $810 \mu \mathrm{g}$ of $\mathrm{s} 9$ homogenate protein per assay
} 
TABLE 11

Mutagenicity of Waters Derived from the Occidenta1 Modified In Situ Shale Oil Process

\begin{tabular}{|c|c|c|c|}
\hline Sample & $\begin{array}{c}\mu g \text { Organic } \\
\text { Carbon }\end{array}$ & Response (TA 98)* & Revertants/ug \\
\hline \multirow{5}{*}{ Boiler Blow-down } & 24 & 19 & 0.8 \\
\hline & 47 & 12 & 0.3 \\
\hline & 120 & 36 & 0.3 \\
\hline & 240 & 64 & 0.3 \\
\hline & 460 & 133 & 0.3 \\
\hline \multirow{6}{*}{ Heat er-Treater } & 7 & 9 & 1.2 \\
\hline & 15 & 21 & 1.4 \\
\hline & 29 & 16 & 0.3 \\
\hline & 74 & 14 & 0.2 \\
\hline & 150 & 23 & 0.2 \\
\hline & 290 & 55 & 0.2 \\
\hline \multirow{5}{*}{ Make-up Water } & 3 & 19 & 5.6 \\
\hline & 7 & 16 & 2.4 \\
\hline & 14 & 11 & 0.8 \\
\hline & 34 & 23 & 0.7 \\
\hline & 68 & 29 & 0.4 \\
\hline \multirow{6}{*}{ Retort Water } & 8 & 13 & 1.71 \\
\hline & 15 & 8 & 0.53 \\
\hline & 30 & 13 & 0.43 \\
\hline & 70 & 26 & 0.4 \\
\hline & 150 & 18 & 0.12 \\
\hline & 300 & 20 & 0.07 \\
\hline
\end{tabular}

*Average of two samples minus background.

Background $=35 \pm 9$ revertant colonies

Metabolic activation was provided by $810 \mu \mathrm{g}$ of S9 homogenate. 
TABLE 12

Mutagenicity of Retort Water and Crude Shale Oil Derived By an Above-Ground Retorting Process

\begin{tabular}{|c|c|c|c|c|}
\hline Sample & $\mu \mathrm{g}$ & $\cdot$ & Response (TA 98) & Revertants/ $\mu \mathrm{g}$ \\
\hline \multirow[t]{6}{*}{ Retort water } & 20 & & $10^{*}$ & 0.5 \\
\hline & 100 & & 43 & 0.4 \\
\hline & 200 & & 75 & 0.4 \\
\hline & 400 & & 175 & 0.4 \\
\hline & 1,000 & & 482 & 0.5 \\
\hline & 2,000 & & 906 & 0.5 \\
\hline \multirow[t]{5}{*}{ Crude Shale Oil } & 250 & & 35 & 0.14 \\
\hline & 500 & $\cdot$ & 51 & 0.10 \\
\hline & 750 & & 70 & $<0.10$ \\
\hline & 1,000 & $\cdot$ & 70 & $<0.10$ \\
\hline & 1,500 & & 64 & $<0.10$ \\
\hline
\end{tabular}

*Average of two samples minus background.

Background $=23 \pm 2$ revertant colonies ( 6 samples)

Metabolic activation provided by $810 \mu \mathrm{g}$ of $\mathrm{S} 9$ homogenate protein per assay 
TABLE 13

Mutagenicity of Column Leachates from Occidental R3E1 Core Samples

\begin{tabular}{|c|c|c|c|}
\hline Sample & Net Revertants (TA 98) & $\mu g$ Carbon & Revertants/ $\mu \mathrm{g}$ \\
\hline 1 & $--^{*}$ & 198 & $<0.27$ \\
\hline $2 \mathrm{~A}$ & $80 \dagger$ & .330 & 0.36 \\
\hline $2 \mathrm{~B}$ & $C \pi$ & 1100 & \\
\hline 3 & 208 & 410 & 1.28 \\
\hline 4 & -- & 420 & $<0.12$ \\
\hline $5 \mathrm{~A}$ & -- & 350 & $<0.14$ \\
\hline $5 \mathrm{~B}$ & - & 1100 & $<0.05$ \\
\hline 6 & 70 & 180 & 0.99 \\
\hline 7 & 34 & 160 & 0.55 \\
\hline 8 & 21 & 170 & 0.31 \\
\hline 9 & $\mathrm{C}$ & 370 & $<0.41$ \\
\hline 10 & $\mathrm{C}$ & 280 & $<0.18$ \\
\hline 11 & -- & 380 & $<0.05$ \\
\hline 12 & - & 290 & $<0.17$ \\
\hline 13 & -- & 160 & $<0.32$ \\
\hline 14 & -- & 580 & $<0.09$ \\
\hline $15 \mathrm{~A}$ & -- & 320 & $<0.16$ \\
\hline $15 B$. & -- & 960 & $<0.05$ \\
\hline $16 \mathrm{~A}$ & -- & 570 & $<0.09$ \\
\hline $16 B$ & -- & 1700 & $<0.03$ \\
\hline $17 \mathrm{~A}$ & - & 380 & $<0.13$ \\
\hline 17B & -- & 1100 & $<0.04$ \\
\hline $18 \mathrm{~A}$ & - & 470 & $<0.11$ \\
\hline $18 \mathrm{~B}$ & -- & 1400 & $<0.04$ \\
\hline
\end{tabular}

Background $=22 \pm 9$ (10 samples) Metabolic activation provided by $810 \mu \mathrm{g} S 9$

* Less than $2 \times$ background

homogenate

${ }^{\dagger}$ Average of two samples minus background

"Contaminated 
Summary

In Vitro Mutagenicity Data

The Ames data provided by LASL and PNL are similar in several respects, but have significant differences. Three main differences are noteworthy:

- LASL detected mutagenic activity in the Occidental product oil and sludge oil. PNL did not detect mutagenic activity in either the Occidental crude shale oil or sludge oil. This is perhaps not a serious discrepancy, since the mutagenicity of the Occidental oils was obviously very weak compared to surface retort crude oil and was essentially at the limits of resolution of the Ames assay.

- Differences in mutagenicity were observed for the process waters. PNL detected activity in boiler blowdown and weak activity in heater-treater water. LASL did not detect activity in either of these waters; however, PNL's assay suggests that mutagenicity was, at best, marginal in this case.

- The two sets of data differ in the comparatively high value observed for the mutagenicity of surface retort process water obtained by LASL as compared with the lower value obtained by PNL. Both laboratories estimated specific activities based on total organic carbon in the water. Because of possible differences in sample storage and sample handling, these measurements should be rechecked, and the samples in question should be exchanged between the two laboratories and assayed for mutagenicity.

Ames assay data by LASL and PNL are in agreement as far as ranking the Occidental and surface retort shale oils in relationship with each other as mutagenic materials. The results from both laboratories assign greater mutagenicity to surface retort than to Occidental shale oils. However, they are not in quantitative agreement. LLL assigns high mutagenic values to the surface retort products. PNL would assign weak or doubtful mutagenicities to all Occidental. materials, excluding the aqueous boiler blowdown samples which were clearly (but weakly) positive in the Ames assay. LASL assigns clear positive values to the product and sludge oils, and differs in its evaluation of the heater-treater water.

These differences cannot be attributable to the sensitivities exhibited by the various tester strains (mainly TA 98) or the activation systems employed in the assays since the positive controls, 2-aminoanthracene and benzo(a)pyrene gave essentially the same mutagenic responses in work done by both laboratories. Moreover, the chemical fractionation procedures (PNL), normally effective in revealing mutagenic components that are poorly resolved during Ames assay of the unfractionated crudes, did not yield mutagenic materials (subfractions) from the Occidental product oil. They did, however, yield active (methanol) subfractions from the Occidental sludge oil. So evidently, masking of the mutagenicity associated with this material occurred in one crude, but not in the other.

These differences serve to underscore the difficulties in making clear quantitative assignments of mutagenicities to chemically complex materials when their mutagenic activity may be of a low order of potency to begin with. They also emphasize the need for a degree of redundancy in the in vitro mutagenicity work before final evaluations are made. 


\section{Manmalian Cell, In Vitro Assay}

Mammalian cells are used to confirm the results from the Ames tests. Besides the usual test with CHO cells described in Appendix B of the "ASEV Modified In Situ Task"Force Research Plan for Occidental Oil Shale, Inc." we will use another rapid and simple test system with mutant strains of hepatoma cells. This test system is now being applied to oil shale samples. We now have two stable strains of mouse hepatoma cells; these differ in sensitivity to benzo(a)pyrene (BaP) and other polyaromatic hydrocarbons (PAH). BaP is toxic to the original strain (HEPA-1) at concentrations as $10 \mathrm{w}$ as $0.1 \mu \mathrm{g} / \mathrm{ml}$. The resistant mutant cell line (HEPA-B-6) can survive and multiply when continuously exposed to BaP at concentrations as high as $3.0 \mu \mathrm{g} / \mathrm{m} \ell$.

The cell strains (approximately $2 \times 10^{4}$ cells) are cultured in plastic trays with depression wells with several dilutions of the test anterials suspected of containing PAHs. Controls include cultures with added BaP with and without test material. After five days, the cells are fixed and strained in the culture wells and are ready for scoring and counting. The end point measured is the lowest concentration of test material that will show differential toxicity between the two strains.

Preliminary results with shale oil have failed to show any differential toxicity on the two cell lines. However, overall toxicity by both strains is higher to crude above-ground retorted shale oil $(11 \mu \mathrm{g} / \mathrm{ml})$ than to the hydrotreated product $(94 \mu \mathrm{g} / \mathrm{m} \ell)$.

\section{HUMAN HEALTH STUDIES}

During the present developmental phase of the industry, occupational health studies can make important contributions to our knowledge of the working conditions and the potential for health problems related to oil shale work. In addition to helping maintain the health of workers presently employed, this knowledge can be applied to future facilities and plants as the industry develops.

In 1978 Occidental Oil Shale; Inc. initiated a program of health surveillance examinations of their employees. The examinations are being conducted by the staff of the Palisade Family Practice Clinic, Palisade, Colorado.

At the present time a proposal is being drafted to initiate a formal occupational health study of the current occidental employees. This study is to be done by the staff of the Palisade Clinic with collaboration of the occupational medical staff of the Los Alamos Scientific Laboratory.

The objectives of the proposed occupational health study are:

- To complete the current cycle of health examinations of the Occidental work force.

- To compile and analyze the results of these health examinations.

- To develop and institute the structure for long-term epidemiologic studies and to collect background data on current employees. 
- To write a report which will

--document the findings of the study

--develop recommendations regarding content and conduct of on-going medical surveillance in the oil shale industry, and

- -make recommendations on possible administrative procedures for centralizing and storing information for epidemiologic study on terminated employees, both within the company and within the industry.

\section{SUMMARY}

The eventual effect of oil shale development on the public health is a primary issue in the beginning debate over the relative risks of utilizing this significant resource. Perceptions vary, and the true risks can only be defined by careful experimentation with materials that are likely to come in contact with industrial or regional populations. Research efforts discussed in this document are in many instances largely prospective; long-term in vivo studies of oil shale-related materials are far from complete and beginning efforts at defining the health status of current worker populations are too preliminary to identify major problems. The largest body of information is drawn from in vitro tests using the SalmonelZa histidine reversion test (Ames assay). The Occidental crude oil and the several associated by-products were found to possess either mutagenic activity of a low order or no activity at all. Early results from inhalation studies with raw shale have failed to demonstrate a carcinogenic effect following 16 months of exposure at dust concentrations considerably higher than anticipated industrial environments.

Industrial hygiene sampling of the mine atmosphere revealed no significant dust levels above standard for nuisance dusts of relatively high silica content. Particles of two distinct physical types were detected. The first, a solid compact particle, was found to possess a higher silica content that the more loosely aggregated porous particles which possess a higher calcium content.

Finally, evaluations of the health of current oil shale workers is just beginning but will serve to lay the groundwork for eventual epidemiological analysis.

\section{PROSPECTIVE STUUDIES}

Assessment of potential health effects associated with oil shale utilization requires comparative studies. Comparisons should be made with materials encountered in processing other synfuels and currently utilized fuels for which control technology requirements have been established. Comparative studies will be particularly useful in the area of mutagenesis and to a lesser extent in studies of in vivo carcinogenesis. 
There is a clear need for classic "skin painting" experiments in which several of the liquid products are tested to verify the results of the Ames test. This assay is utilized to establish dose-response relationships for any suitable material of interest and for comparison with known carcinogens and other energy related materials. It should be understood that this assay serves as an in vivo test for oncogenicity within the limits imposed by experimental exposure conditions. Current plans include dose-response experiments using product oil from Retort 6 as part of a comparative study which incorporates both crude oil and upgraded crude oils from surface processes as well as API reference petroleums.

Mutagenesis screening and other in vitro tests will also be carried out on leachates from spent shales. These studies should include several types of spent shales and a variety of leaching procedures.

Continuing studies are outlined in Appendix B of "ASEV Modified In Situ Task Force Research Plan for Occidental Oil Shale, Inc." for in situ processing of oil shale. These include skin painting carcinogenesis studies, teratogenic studies, short-term toxicity studies, and long-term animal studies to identify functional diseases which may result from exposure. Planned future studies include determination of the effects of such combined studies as skin painting with U.V. exposure and inhalation studies with more realistic mine dusts (e.g., nitrates from explosives, diesel exhaust, radon daughters). 
APPENDIX A

Processing History of Retort 3E That May Affect The 3E-1 Core Samples 
Occidental's modified in situ oil shale process utilizes underground retorts filled with rubblized oil shale. By processing the oil shale underground, the cost of recovering the shale oil is less and the environmental impact is reduced. In preparing these underground retorts, a void is first created by mining out $20-30 \%$ of the 0 il shale in the retort. This void is then eveniy distributed throughout the rest of the retort by rubblizing the oil shale in the retort with conventional explosives. The walls of this retort are the unbroken oil shale surrounding the rubblized oil shale. After the retort is prepared, the oil shale at the top of the retort is ignited with a conventional burner. After burning in the retort is established, the burners are shut off and the burning front is maintained by supplying air to the retort. As the oil shale is heated to $900^{\circ} \mathrm{F}$, the organic part of the oil shale decomposes into oil, gas and carbon. The carbon that is left behind is used as fuel for the combustion front. The oil drains down the retort and is collected.

In order to gather data on this process, Occidental at their D.A. Shale site, prepared and processed three small retorts before testing commercial size retorts. Retort $3 E$ was the third in this series. Retort $3 E$ was designed to test the affect of blasting to a horizontal freeface rather then to a center raise, as was done in Retorts $I E$ and $2 E$. Retort $3 E$ is $32 \mathrm{ft}$. $x 32 \mathrm{ft}$. $x$ $113 \mathrm{ft}$. tall. It contained oil shale with an average Fischer Assay of 19.1 gallons per ton. It was started up on February 10, 1975. The retort was operated in an air-recycle mode with a inlet gas velocity of 0.62 SCFM per square foot. The air was $70 \%$ of the inlet gas and the recycle was the remaining $30 \%$. The retort was shut down on July 18, 1375. There were 3 thermocouple bundles installed in the retort which had thermocouples every three feet. One thermocouple bundle burned out at start-up. The other two lasted until April 18, 1975.

In order to determine the environmental effects of a spent in situ oil shale retort, a core was taken from Retort $3 E$ in December 1978. There are several factors that could affect the analysis of this core. These factors will be divided into the following four areas: temperature history, gas environment, liquid injection into the retort, and drilling agents used in taking of the core samples.

Temperature Histories

The best temperature information available for each core sample is shown in Tables 1-9. The temperatures used in these core sample time-temperature histories are from the thermocouple bundle inserted into hole $\mathrm{LW}-43$ which is the closest thermocouple bundle to core $3 E-1$. The thermocouples did not last through the entire retort but they do give the temperature history from February 11, 1975, the day after the start-up to Apri1 17, 1975. The thermocouples were located vertically every three feet. The thermocouple closest 
to the depth of the sample was used. These.time-temperature histories are incomplete but give an indication of the type of time-temperature history one could expect the core samples to have undergone.

Gas Environment

Because Retort $3 E$ was operated in a recycle mode, the spent shale saw an environment that includes organic gases, carbon dioxide, and $\mathrm{H}_{2} \mathrm{~S}$. Commercial retorts will be operated with air-steam and no recycle. An average composition of the off-gas produced in Retort $3 E$ was:

\begin{tabular}{lc} 
Component & Percent \\
\cline { 2 - 2 } Hydrogen & 1.8 \\
Nitrogen & 71.7 \\
Oxygen & 14.1 \\
Argon & 1.1 \\
Carbon Monoxide & 1.5 \\
Methane & 0.3 \\
Carbon Dioxide & 9.4 \\
Ethane & 0.1 \\
Hydrogen Disulfide & 0.05
\end{tabular}

Before entering the retort, the recycle gas went through a wet scrubber. This wet scrubber was out of operation intermittently during retorting. No analysis was made of gas composition after treatment by the wet scrubber.

The spent oil shale sample was exposed to recycle gas for varying amounts of time depending on the depth of the sample. The upper spent shale would have been in contact with recycle gas for almost the entire retorting period whereas the spent shale from lower down in the retort would have seen it only for a limited amount of time.

The recycle gas contained some oil, either as aerosol or as vapor. This oil probably condensed on the spent shale, accounting for some of the organic matter in the core samples. This oil would not be found in spent shale from a commercial retort since there will be no recycle. No accurate measurements of the $0 i 1$ in Retort $3 E$ off-gas were made. Using the loading of oil mist in the exit gas of Retort 6, approximately 70 barrels of oil was recycled back into Retort 3E.

On July 1, 1975, Retort $3 E$ was shut down and went under total recycle. This means that all the spent shale in the retort saw a gas of approximately the following composition for two weeks:

Component

Hydrogen

Nitrogen

Oxygen

Argon

Carbon Monoxide

Methane

Carbon Dioxide

Ethane

Hydrogen Disulfide

\section{Percent}

17.7

29.3

0.0

0.3

4.2

20.0

24.8

2.6

0.2 
This again is not typical for a commercial retort.

\section{Liquid Injection}

There are several times when liquids were injected into Retort 3E. These injections may have affected the spent shale that was sampled. During the retorting, the following amounts of water were injected:

\section{Date}

May 21,1975

May $22-28,1975$

June 12,1975

June 19-July 1,1975

JuTy $16-18,1975$
Gallons of Water

$$
\begin{array}{r}
2,016 \\
8,640 \\
10,000 \\
17,000(1 \mathrm{gpm}) \\
5,760
\end{array}
$$

The water injected this way was meant to vaporize and act as steam diluent for the inlet air. It is likely that most of the water was absorbed by the spent shale in the upper part of the retort.

\section{Drilling Agents Contamination}

In Table 10 is an analysis of several drilling agents that were used in obtaining Core $3 \mathrm{E}-1$. These drilling agents may or may not have contaminated the core sample, but the core should be analyzed in light of these findings.

\section{Summary}

Out of all these factors that might affect the spent shale core samples, only the time-temperature histories could be considered representative of a commercial operation. The water injection, hydrocarbon gas environment, and drilling agent contamination are all things that one would not find in a commercial operation. 


\section{RETORT 3E CORE SAMPLE TIME-TEMPERATURE HISTORY}

\begin{tabular}{|c|c|c|c|c|c|c|c|c|c|c|}
\hline $\begin{array}{l}\text { Sample } \\
\text { Number }\end{array}$ & $\begin{array}{l}\text { Depth of } \\
\text { Sample } \\
(\mathrm{ft})\end{array}$ & $\begin{array}{c}\text { Depth of } \\
\text { Temperature } \\
(\mathrm{ft})\end{array}$ & \multicolumn{8}{|c|}{$\begin{array}{c}\text { Temperature } \\
\left({ }^{\circ} \mathrm{F}\right)\end{array}$} \\
\hline 2 & $454-457$ & 456 & 122 & 244 & 345 & 450 & 673 & 809 & 728 & 807 \\
\hline 3 & $457-460$ & 459 & 263 & 1259 & 1393 & 1405 & 1566 & 1608 & 1479 & 1599 \\
\hline 5 & $46 ?-466$ & 465 & 165 & 412 & 275 & 1033 & 1214 & 1390 & 1516 & 1622 \\
\hline 6 & $468-469$ & 468 & 126 & 167 & 127 & 534 & 782 & 977 & 1191 & 1313 \\
\hline 7 & $469-470.5$ & 471 & 65 & 126 & 107 & 176 & 266 & 378 & 519 & 707 \\
\hline 8 & $470-475$ & 474 & 44 & 61 & 76 & 123 & 129 & 137 & 144 & 174 \\
\hline 9 & $475-477$ & 477 & 44 & 45 & 67 & 120 & 121 & 122 & 122 & 119 \\
\hline 13 & $481.5-485.5$ & 483 & 0 & 50 & 0 & 79 & 114 & 122 & 124 & 121 \\
\hline 14 & $484-485$ & 483 & 0 & 50 & 0 & 79 & 114 & 122 & 124 & 121 \\
\hline 15 & $483.5-485.5$ & 483 & 0 & 50 & 0 & 79 & 114 & 122 & 124 & 121 \\
\hline 16 & $485.5-500.5$ & 489 & 0 & 0 & 0 & 55 & 57 & 66 & 86 & 102 \\
\hline 17 & $500-506$ & 504 & 0 & 0 & 0 & 0 & 45 & 52 & 69 & 77 \\
\hline 18 & $506-515$ & 510 & 0 & 0 & 0 & 0 & 45 & 59 & 62 & 80 \\
\hline
\end{tabular}


RETORT 3E COPE SAMPLE TIME-TEMPERATURE HISTORY

(19.75)

\begin{tabular}{|c|c|c|c|c|c|c|c|c|c|c|c|}
\hline $\begin{array}{l}\text { Samp le } \\
\text { Number }\end{array}$ & $\begin{array}{c}\text { Depth of } \\
\text { Sample }\end{array}$ & $\begin{array}{l}\text { Depth of } \\
\text { Temperature }\end{array}$ & & & & Tempe & ture & & & & \\
\hline & & & $2-19$ & $2-20$ & $2-21$ & $2-22$ & $2-23$ & $2-24$ & $2-25$ & $2-26$ & \\
\hline 1 & $442-445$ & 444 & 0 & 0 & 0 & 0 & 0 & 0 & 0 & 0 & \\
\hline 2 & $454-457$ & 456 & 1031 & 0 & 992 & 865 & $948^{\circ}$ & 1580 & 1429 & 886 & \\
\hline 3 & $457-460$ & 459 & 1659 & 0 & 1468 & 1459 & 1550 & 1566 & 1572 & 1468 & \\
\hline 4 & $460-463$ & 462 & 1622 & 0 & 1524 & 1514 & 1543 & 1589 & 1588 & 1500 & \\
\hline 5 & $463-.466$ & 465 & 1652 & 0 & 1619 & 1583 & 1563 & 1425 & 1468 & 1552 & \\
\hline 6 & $468-469$ & 468 & 1234 & 0 & 1633 & 1672 & 1603 & 900 & 1018 & 1584 & \\
\hline$?$ & $469-470.5$ & 471 & 872 & 0 & 1160 & 1274 & 1359 & 556 & 666 & 1505 & \\
\hline 8 & $470-475$ & 474 & 259 & 0 & 487 & 607 & 759 & 273 & 382 & 1068 & \\
\hline 9 & $475-477$ & 477 & 120 & 0 & 174 & 257 & 400 & 129 & 135 & 738 & \\
\hline 10 & $475.5-477.5$ & 477 & 120 & 0 & 174 & 257 & 400 & 129 & 135 & 738 & \\
\hline 11 & $477-480$ & 480 & 119 & 0 & 127 & 148 & 188 & 123 & 122 & 459 & \\
\hline 12 & $480.5-481.5$ & 480 & 119 & 0 & 127 & 148 & 188 & 123 & 122 & 459 & \\
\hline 13 & $481.5-485.5$ & 483 & 116 & 0 & 116 & 121 & 124 & 120 & 121 & 146 & 勇 \\
\hline 14 & $484-485$ & 483 & 116 & 0 & 116 & 121 & 124 & 120 & 121 & 146 & \\
\hline 15 & $483.5-485.5$ & 483 & 116 & 0 & 116 & 121 & 124 & 120 & 121 & 146 & \\
\hline 16 & $485.5-500.5$ & 489 & 110 & 0 & 115 & 117 & 118 & 104 & 10.7 & 124 & \\
\hline 17 & $500-506$ & 504 & 95 & 0 & 89 & 108 & 116 & 143 & 136 & 114 & \\
\hline 18 & $506-515$ & 510 & 102 & 0 & 89 & 108 & 116 & 69 & 68 & 119 & \\
\hline
\end{tabular}




\section{RETORT 3E CORE SAMPLE TIME-TEMPERATURE HISTORY} $(4975)$

\begin{tabular}{|c|c|c|c|c|c|c|c|c|c|c|c|}
\hline \multirow[t]{2}{*}{$\begin{array}{l}\text { Sanp le } \\
\text { Number }\end{array}$} & \multirow{2}{*}{$\begin{array}{l}\text { Depth of } \\
\text { Sample } \\
(\mathrm{ft})\end{array}$} & \multirow{2}{*}{$\begin{array}{c}\text { Depth of } \\
\text { Temperature } \\
\text { (ft) }\end{array}$} & \multicolumn{8}{|c|}{$\begin{array}{c}\text { Temperature } \\
\left({ }^{\circ} \mathrm{F}\right)\end{array}$} & \\
\hline & & & $2-27$ & $2-28$ & $3-1$ & $3-2$ & $3-3$ & $3-4$ & $3-5$ & $3-6$ & \\
\hline 1 & $442-445$ & 444 & 0 & 0 & 0 & 0 & 0 & 0 & 0 & 0 & \\
\hline 2 & $454-457$ & 456 & 999 & 809 & 641 & 563 & 203 & 964 & 827 & 706 & \\
\hline 3 & $457-460$ & 459 & 1545 & 1444 & 1397 & 1410 & 271 & 1412 & 1326 & 1211 & \\
\hline 4 & $460-463$ & 462 & 1549 & 1543 & 1500 & 1507 & 710 & 1539 & 1487 & 1460 & \\
\hline 5 & $463-466$ & 465 & 1542 & 1555 & 1555 & 1545 & 1459 & 1556 & 1552 & 1538 & \\
\hline 6 & $468-469$ & 468 & 1573 & 1570 & 1573 & 1569 & 1541 & 1556 & 1569 & 1568 & \\
\hline 7 & $469-470.5$ & 471 & 1531 & 1553 & 1569 & 15.77 & 1547 & 1578 & 1582. & 1586 & \\
\hline 8 & $470-475$ & 474 & 1173 & 1275 & 1347 & 1358 & 3897 & 1497 & 1533 & 1556 & \\
\hline 9 & $475-477$ & 477 & 889 & 969 & 1020 & 1087 & 1578 & 1253 & 1308 & 1345 & \\
\hline 10 & $475.5-477.5$ & 477 & 889 & 969 & 1020 & 1087 & 1578 & 1253 & 1308 & 1345 & \\
\hline 11 & $477-480$ & 480 & 616 & 725 & 814 & 889 & 1448 & 1009 & 1045 & 1041 & \\
\hline 12 & $480.5-481.5$ & 480 & 616 & 725 & 814 & 889 & 1448 & 1009 & 1045 & 1041 & \\
\hline 13 & $481.5-485.5$ & 483 & 185 & 262 & 370 & 479 & 1167 & 666 & 735 & 762 & 7 \\
\hline 14 & $484-485$ & 483 & 185 & 262 & 370 & 479 & 1167 & 666 & 735 & 762 & \\
\hline 15 & $483.5-485.5$ & 483 & 185 & 262 & 170 & 479 & 1167 & 666 & 735 & 762 & \\
\hline 16 & $485.5-500.5$ & 489 & 129 & 127 & 128 & 129 & 576 & 132 & 139 & 147 & \\
\hline 17 & $500-506$ & 504 & 141 & 177 & 125 & 188 & 147 & 108 & 115 & 131 & \\
\hline 18 & $506-515$ & 510 & 147 & 183 & 124 & 205 & 145 & 108 & 116 & 119 & \\
\hline
\end{tabular}


RETORT 3E CORE SAMPLE TIME-TEMPERATURE HISTORY (1975)

\begin{tabular}{|c|c|c|c|c|c|c|c|c|c|c|}
\hline \multirow[t]{2}{*}{$\begin{array}{l}\text { Sample } \\
\text { Number }\end{array}$} & \multirow{2}{*}{$\begin{array}{c}\text { Depth of } \\
\text { Sample } \\
(\mathrm{ft})\end{array}$} & \multirow{2}{*}{$\begin{array}{c}\text { Depth of } \\
\text { Temperature } \\
(\mathrm{ft})\end{array}$} & \multicolumn{8}{|c|}{$\begin{array}{c}\text { Temperature } \\
\left({ }^{\circ} \mathrm{F}\right)\end{array}$} \\
\hline & & & $3-7$ & $3-8$ & $3-9$ & $3-10$ & $3-11$ & $3-12$ & $3-13$ & $3-14$ \\
\hline 1 & $442-445$ & 444 & 0 & 0 & 0 & 0 & 0 & 0 & 0 & 0 \\
\hline 2 & $454-457$ & 456 & 755 & 811 & 797 & 842 & 818 & 679 & 568 & 481 \\
\hline 3 & $457-460$ & 459 & 1244 & 1229 & 1191 & 1144 & 970 & 787 & 704 & 651 \\
\hline 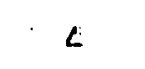 & $460-463$ & 462 & 1426 & 1399 & 1381 & 1353 & 1232 & 1022 & 863 & 763 \\
\hline 5 & $463-466$ & 465 & 1524 & 1503 & 1485 & 1465 & 1421 & 1327 & 1245 & 1142 \\
\hline 6 & $468-469$ & 468 & 1563 & 1554 & 1544 & 1532 & 1502 & 1463 & 1417 & 1366 \\
\hline 7 & $469-470.5$ & 471 & 1588 & 1585 & 1582 & 1577 & 1570 & 1556 & 1541 & 1520 \\
\hline 8 & $470-475$ & 474 & 1573 & 1582 & 1592 & 1592 & 1596 & 1586 & 1573 & 1560 \\
\hline 9 & $475-477$ & 477 & 1406 & 1490 & 1531 & 1559 & 1620 & 1573 & 1552 & 1534 \\
\hline 10 & $475.5-477.5$ & 477 & 1406 & 1490 & 1531 & 1559 & 1620 & 1573 & 1552 & 1534 \\
\hline 11 & $477-480$ & 480 & 1093 & 1133 & 1161 & 1197 & 1282 & 1370 & 1387 & 1391 \\
\hline 12 & $480.5-481.5$ & 480 & 1093 & 1133 & 1161 & 1197 & 1282 & 1370 & 1387 & 1391 \\
\hline 13 & $481.5-485.5$ & 483 & 781 & 824 & 838 & 859 & 921 & 1007 & 1101 & 1193 \\
\hline 14 & $484-485$ & 483 & 781 & 824 & 838. & 859 & 921 & 1007 & 1101 & 1193 \\
\hline 15 & $483.5-485.5$ & 483 & 781 & 824 & 838 & 859 & 921 & 1007 & 1101 & 1193 \\
\hline 16 & $485.5-500.5$ & 489 & 153 & 156 & 167 & 179 & 199 & 247 & 311 & 400 \\
\hline 17 & $500-506$ & 504 & 149 & 151 & 163 & 59 & 107 & 94 & 96 & 105 \\
\hline 18 & $506-515$ & 510 & 149 & 151 & 163 & 58 & 111 & 98 & 98 & 103 \\
\hline
\end{tabular}


RETORT 3E CORE SAMPLE TIME-TEMPERATURE HISTORY

(1975)

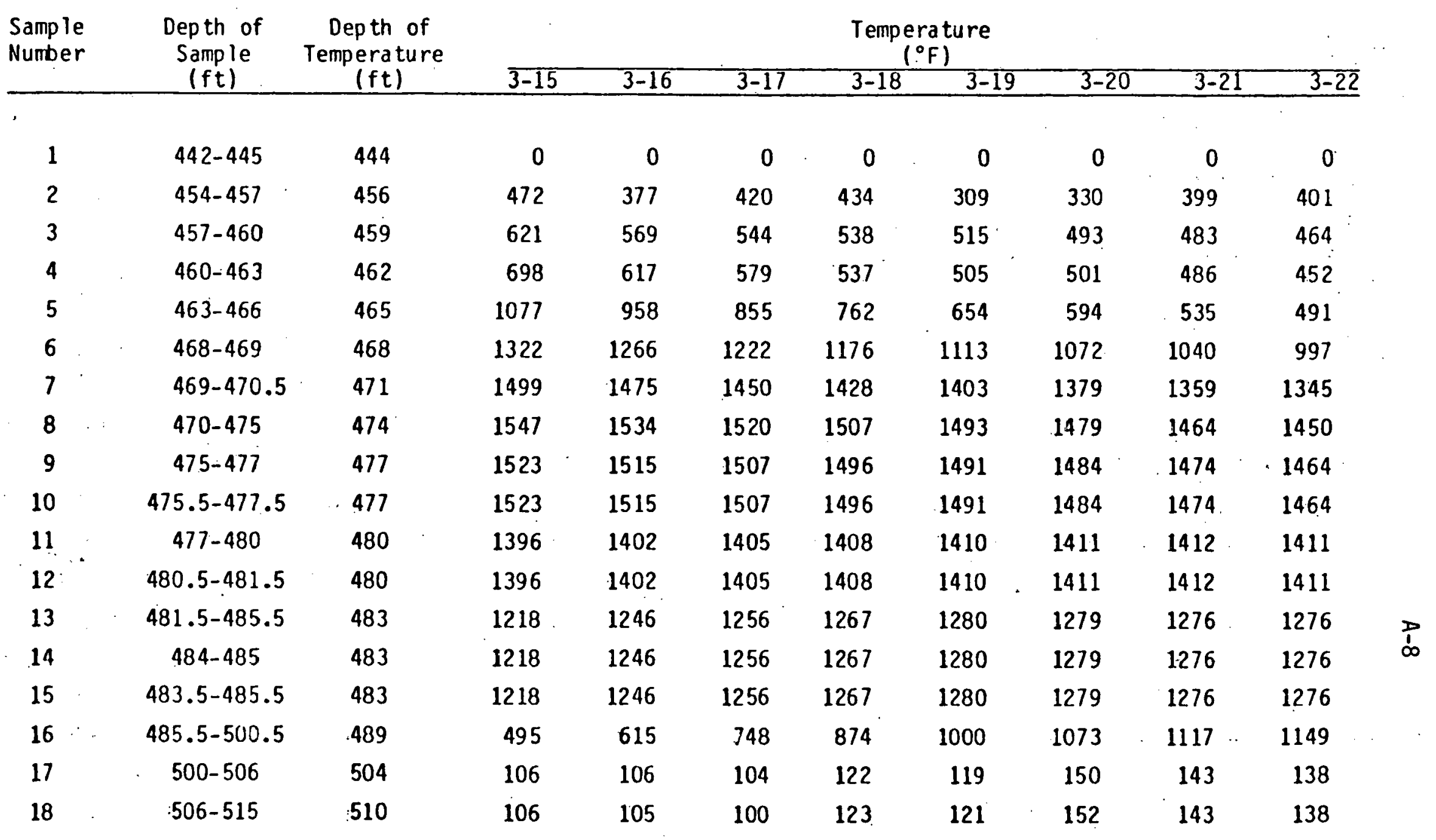




\section{... RETORT 3E CORE SAMPLE TIME-TEMPERATURE HISTORY} (1975)

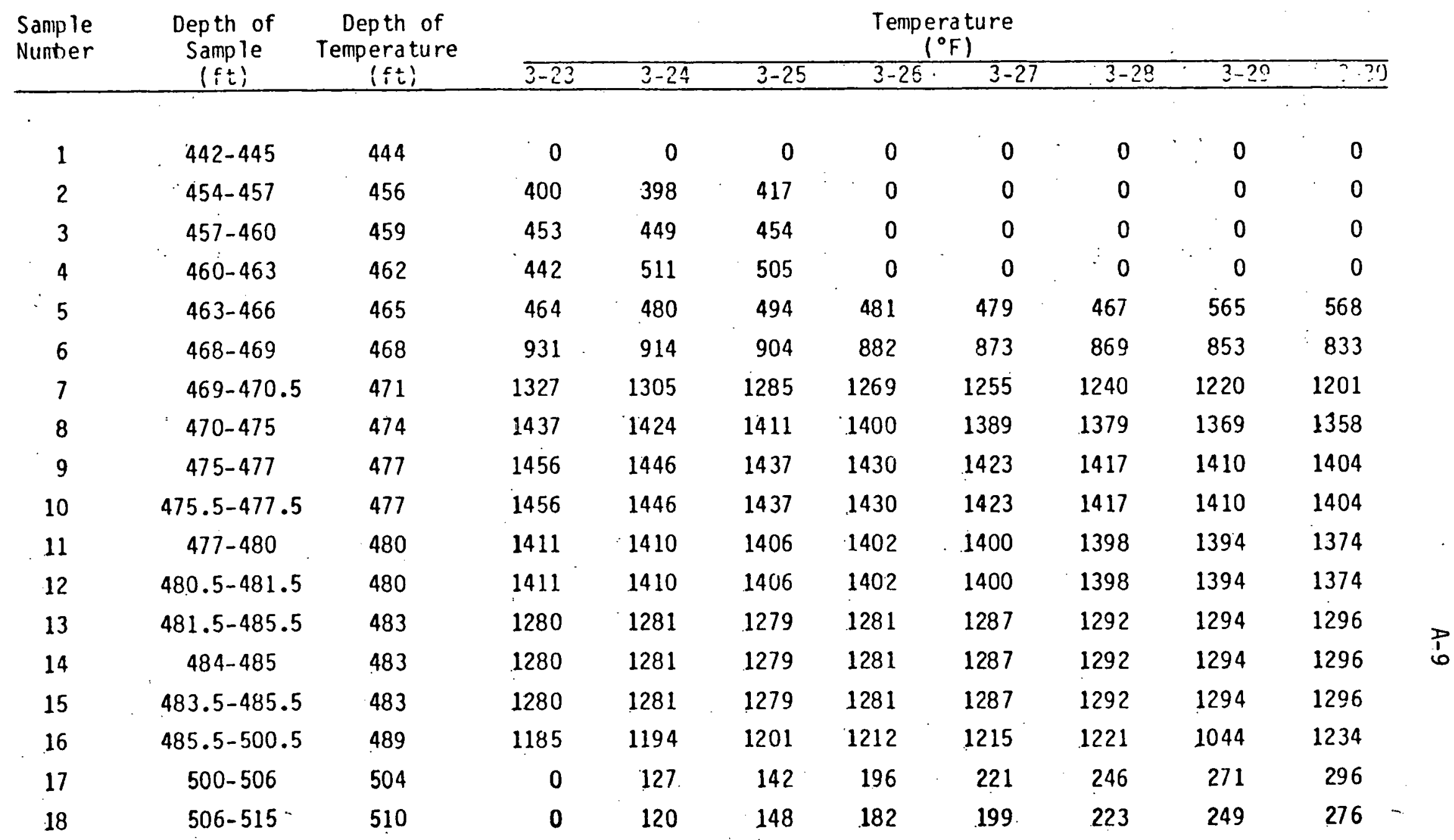




\section{RETORT 3E CORE SAIPLE TIME-TEMPERATURE HISTORY}

\section{(1975)}

\begin{tabular}{|c|c|c|c|c|c|c|c|c|c|c|}
\hline \multirow[t]{2}{*}{$\begin{array}{l}\text { Sample } \\
\text { Number }\end{array}$} & \multirow{2}{*}{$\begin{array}{c}\text { Depth of } \\
\text { Sample } \\
\text { (ft) }\end{array}$} & \multirow{2}{*}{$\begin{array}{c}\text { Depth of } \\
\text { Temperature } \\
\text { (ft) }\end{array}$} & \multirow{2}{*}{\multicolumn{8}{|c|}{$\begin{array}{c}\text { Temperature } \\
\left({ }^{\circ} \mathrm{F}\right)\end{array}$}} \\
\hline & & & $3-31$ & $4-1$ & $4-2$ & & & & $4-6$ & $4-7$ \\
\hline 1 & $442-445$ & 444 & 0 & 0 & 0 & 0 & 0 & 0 & 0 & 0 \\
\hline 2 & $454-457$ & 456 & 0 & 0 & 0 & 0 & 0 & 0 & 0 & 0 \\
\hline 3 & $457-460$ & 459 & 0 & 0 & 0 & 0 & 0 & 0 & 0 & 0 \\
\hline 4 & $460-463$ & 462 & 0 & 0 & 0 & 0 & 0 & 0 & 0 & 0 \\
\hline 5 & $463-466$ & 465 & 662 & 669 & 658 & 577 & 507 & 469 & 448 & 428 \\
\hline 6 & $468-469$ & 468 & 850 & 872 & 891 & 922 & 954 & 993 & 1055 & 1136 \\
\hline 7 & $469-470.5$ & 471 & 1187 & 1178 & 1175 & 1183 & 1206 & 1223 & 1236 & 1245 \\
\hline 8 & $470-475$ & 474 & 1348 & 1337 & 1329 & 1321 & 1320 & 1320 & 1319 & 1318 \\
\hline 9 & $475-477$ & 477 & 1398 & 1391 & 1386 & 1378 & 1378 & 1378 & 1376 & 1374 \\
\hline 10 & $475.5-477.5$ & 477 & 1398 & 1391 & 1386 & 1378 & 1378 & 1378 & 1376 & 1374 \\
\hline 11 & 477-480 & 480 & 1387 & 1383 & 1381 & 1380 & 1378 & 1377 & 1382 & 1384 \\
\hline 12 & $480.5-481.5$ & 480 & 1387 & 1383 & 1381 & 1380 & 1378 & 1377 & 1382 & 1384 \\
\hline 13 & $481.5-485.5$ & 483 & 1302 & 1311 & 1317 & 1320 & 1321 & 1322 & 1324 & $132^{7}$ \\
\hline 14 & $484-485$ & 483 & 1302 & 1311 & 1317 & 1320 & 1321 & 1322 & 1324 & 1327 \\
\hline 15 & $483.5-485.5$ & 483 & 1302 & 1311. & 1317 & 1320 & 1321 & 1322 & 1324 & 1327 \\
\hline 16 & $485.5-500.5$ & 489 & 1230 & 1217 & 1206 & 1197 & $1191^{\circ}$ & 1184 & 1179 & 1175 \\
\hline 17 & $500-506$ & 504 & .318 & 338 & 357 & 376 & 394 & 409 & 424 & 440 \\
\hline 18 & $506-515$ & 510 & 305 & 333 & 355 & 371 & 388 & 404 & 420 & 433 \\
\hline
\end{tabular}




\section{RETORT 3E CORE SAPIPLE TIME-TEMPERAT.URE HISTORY}

\section{(I. 75$)$}

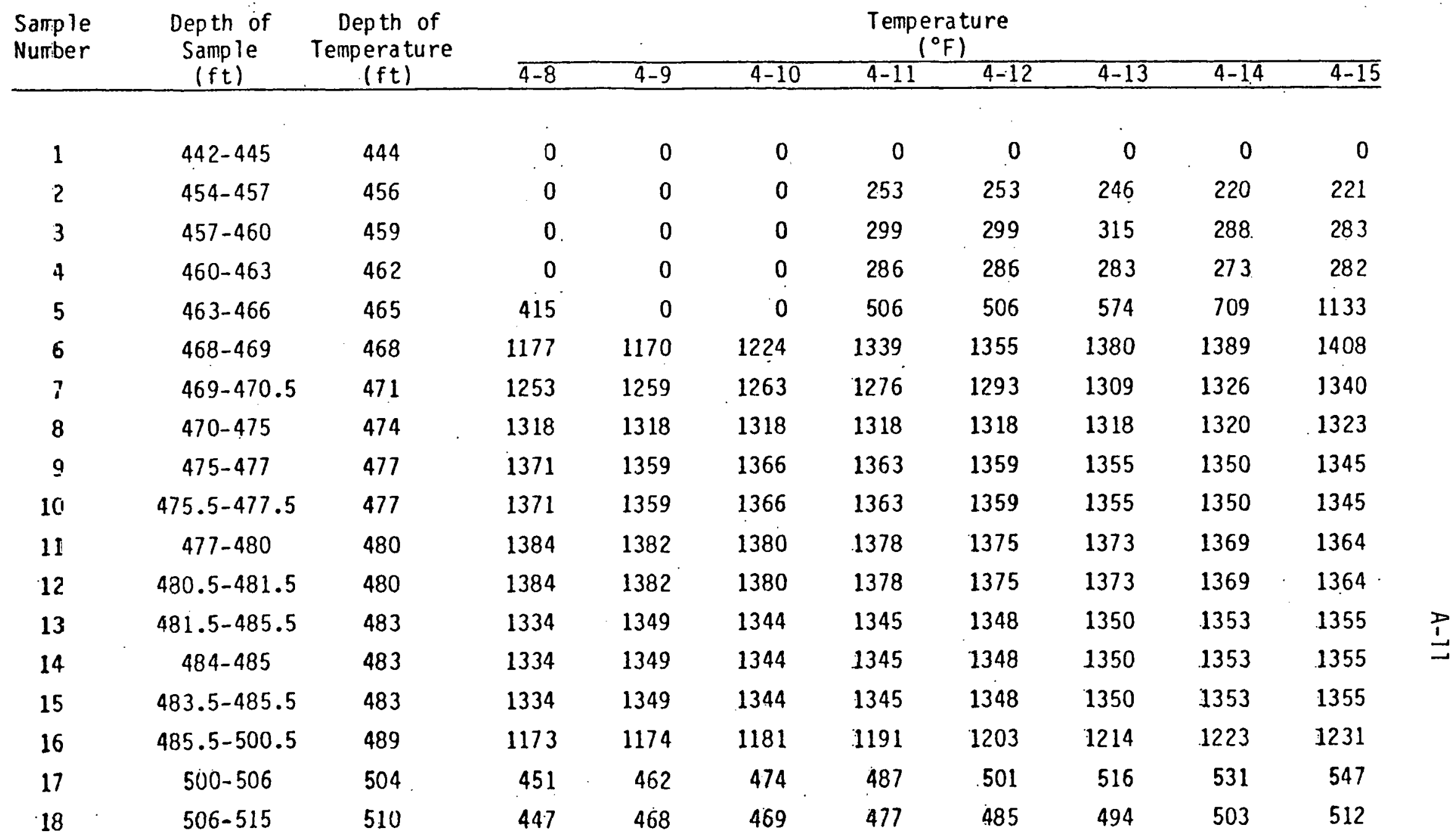




\section{RETORT 3E CORE SAMPLE TIME-TEMPERATURE HISTORY}

\section{(1975)}

\begin{tabular}{|c|c|c|c|c|c|c|c|c|c|c|}
\hline $\begin{array}{l}\text { Sample } \\
\text { Number }\end{array}$ & $\begin{array}{l}\text { Depth of } \\
\text { Sample }\end{array}$ & $\begin{array}{l}\text { Depth of } \\
\text { Temperature }\end{array}$ & & & & $\begin{array}{r}\text { Tempe } \\
\quad\end{array}$ & & & & \\
\hline & & $(f t)$ & $4-16$ & $4-17$ & $4-18$ & $4-19$ & $4-20$ & $4-21$ & $4-22$ & $4-23$ \\
\hline 1 & $442-445$ & 444 & 0 & 0 & 0 & 0 & 0 & 0 & 0 & 0 \\
\hline 2 & $454-457$ & 456 & 199 & .159 & 0 & 0 & 0 & 0 & 0 & 0 \\
\hline 3 & $457-460$ & 459 & 258 & 160 & 0 & 0 & 0 & 0 & 0 & 0 \\
\hline 4 & $460-463$ & 462 & 258 & 161 & 0 & 0 & 0 & 0 & 0 & 0 \\
\hline 5 & $463-466$ & 465 & 1178 & 161 & 0 & 0 & 0 & 0 & 0 & 0 \\
\hline 6 & $468-469$ & 468 & 1430 & 1309 & 0 & 0 & 0 & 0 & 0 & 0 \\
\hline 7 & $469-470.5$ & 471 & 1355 & 1317 & 0 & 0 & 0 & 0 & 0 & 0 \\
\hline 8 & $470-475$ & 474 & 1327 & 1298 & 0 & 0 & 0 & 0 & 0 & 0 \\
\hline 9 & $475-477$ & 477 & 1340 & 1312 & 0 & 0 & 0 & 0 & 0 & 0 \\
\hline 10 & $475.5-477.5$ & 477 & 1340 & 1312 & 0 & 0 & 0 & 0 & 0 & 0 \\
\hline 11 & $477-480$ & 480 & 1357 & 1330 & 0 & 0 & 0 & 0 & 0 & 0 \\
\hline 12 & $480.5-481.5$ & 480 & 1357 & 1330 & 0 & 0 & 0 & 0 & 0 & 0 \\
\hline 13 & $481.5-485.5$ & 483 & 1356 & 1323 & 0 & 0 & 0 & 0 & 0 & 0 \\
\hline 14 & $484-485$ & 483 & 1356 & 1323 & 0 & 0 & 0 & 0 & 0 & 0 \\
\hline 15 & $483.5-485.5$ & 483 & 1356 & 1323 & 0 & 0 & 0 & 0 & 0 & 0 \\
\hline 16 & $485.5-500.5$ & 489 & 1237 & 1212 & 0 & 0 & 0 & 0 & 0 & 0 \\
\hline 17 & $500-506$ & 504 & 563 & 562 & 0 & 0 & 0 & 0 & 0 & 0 \\
\hline 18 & $506-515$ & 510 & 521 & 485 & 0 & 0 & 0 & 0. & 0 & 0 \\
\hline
\end{tabular}


Table 10

Analysis if Orilling Agents Used in the Recovery of Occidental Oil Shale Spent Shale Core 3-1

(ppm)

\begin{tabular}{|c|c|c|c|}
\hline Alum inum & $<1$ & $65+3$ & - \\
\hline Arsenic & $<0.8$ & $<0.3$ & $18+5$ \\
\hline Boron & $0.5+0.1$ & $9+1$ & - \\
\hline Bromine & $2+0.5$ & $<0.3$ & $<2$ \\
\hline Calcium & $<300$ & $<300$ & $4500 \pm 2000$ \\
\hline Chlorine & $70 \pm 100$ & $42000+3000$ & $<400$ \\
\hline Chromium & $<4$ & $<5$ & $37 \pm 11$ \\
\hline Cobalt & $<1$ & $<1$ & $<26$ \\
\hline Copper & $3.6 \pm 0.4$ & $3.2 \pm 0.4$ & $<19$ \\
\hline Iron & $20+2$ & $125 \pm 7$ & $167 \pm 12$ \\
\hline Lead & $<1$ & $<1$ & $330+30$ \\
\hline Magnesium & $0.3+0.1$ & $5+1$ & - \\
\hline Manganese & $<2$ & $<2$ & $<17$ \\
\hline Mierçury & $<1$ & $<1$ & - \\
\hline Nickel & $<0.6$ & $<0.6$ & $24 \pm 5$ \\
\hline Potassium & $<600$ & $<600$ & - $\quad<200$ \\
\hline Rubidium & $<0.4$ & $<0.4$ & $<2$ \\
\hline Selenium & $<0.3$ & $<0.3$ & $<2$ \\
\hline Silicon & $<5$ & $200+20$ & $<0.6$ \\
\hline Sodium, & $410+30$ & $3000+3000$ & - \\
\hline Strontium & $<4$ & $<4$ & $<13$ \\
\hline Sulfur & $9400+7000$ & $<9000$ & $1200+400$ \\
\hline Titanium & $<35$ & $<35$ & $<35$ \\
\hline Vanadium & $<9$ & $<9$ & $<7$ \\
\hline Zinc & $10.8+0.6$ & $7.8 \pm 0.6$ & $260,000 \pm 20,000$ \\
\hline $\begin{array}{l}\text { Tulal organic } \\
\text { carbon }\end{array}$ & 292,000 & $242,000$. & - \\
\hline
\end{tabular}




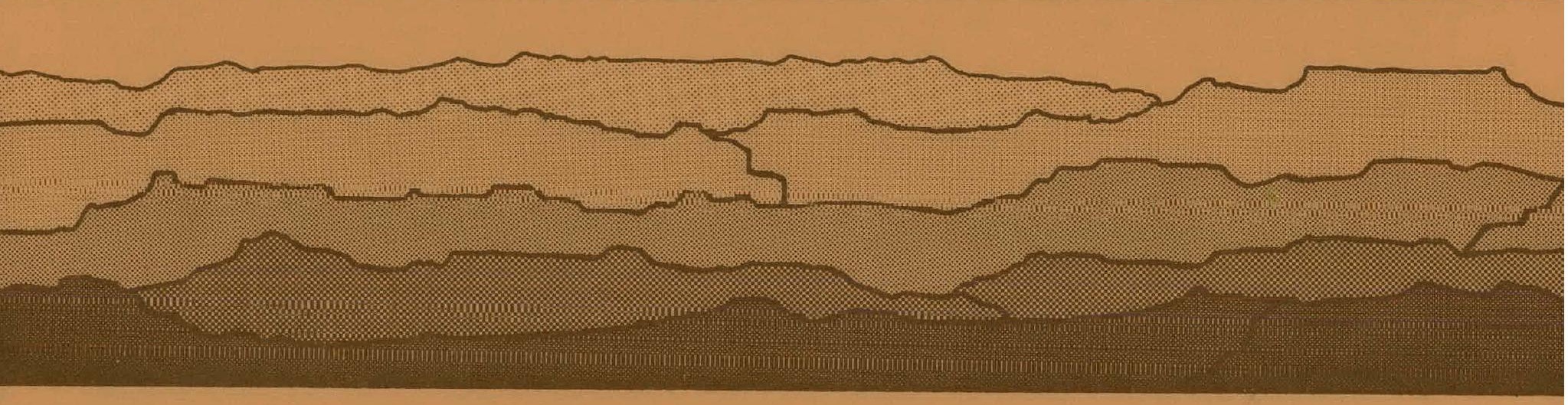

